RENATO FideLIS IVANOVIC

\title{
Análise de miRNAs envolvidos na regulação da MMP9 e consequências no processo de invasão celular do adenocarcinoma da próstata: estudo in vivo e in vitro
}

Tese apresentada à Faculdade de Medicina da Universidade de São Paulo para obtenção do título de Doutor em Ciências

Programa de Urologia

Orientadora: Dra. Sabrina Thalita dos Reis

São Paulo 


\section{Dados Internacionais de Catalogação na Publicação (CIP)}

Preparada pela Biblioteca da

Faculdade de Medicina da Universidade de São Paulo

Creprodução autorizada pelo autor

Ivanovic, Renato Fidelis

Análise de miRNAs envolvidos na regulação da MMP9

e consequências no processo de invasão celular do

adenocarcinoma da próstata : estudo in vivo e in

vitro / Renato Fidelis Ivanovic. -- São Paulo,

2018.

Tese(doutorado)--Faculdade de Medicina da

Universidade de São Paulo.

Programa de Urologia.

Orientadora: Sabrina Thalita dos Reis Faria.

Descritores: 1.Neoplasias da próstata

2. Metaloproteinases da matriz 3. Inibidor tecidual

de metaloproteinase 4.MicroRNAs 5. miR-21 6.miR-338-

3p 7.Ensaio de imunoadsorção enzimática 8.qRT-PCR

9. Matrigel 10. Proteína RECK

USP / FM/DBD $-296 / 18$

Responsável: Eidi Raquel Franco Abdalla - CRB-8/4901 


\section{Agradecimentos}

À minha orientadora, Prof. Dra. Sabrina Reis, que me convidou para ingressar neste trabalho e que durante este período me ajudou e ensinou pacientemente as etapas fundamentais da elaboração de uma pesquisa científica. Agradeço pela oportunidade em realizar um trabalho que acrescentou uma nova visão sobre a importância em se aprofundar no campo da biologia molecular e como ela pode nos tornar melhores profissionais.

À Dra. Nayara Viana, uma pessoa de grande conhecimento na área de biologia molecular com quem aprendi não apenas conceitos importantes, mas também o significado de companheirismo e empenho para ajudar os amigos.

Ao meu amigo e futuro colega de profissão, Denis Reis Morais, que me ensinou à não desistir quando algo dá errado e acima de tudo buscar soluções sempre com otimismo e alegria.

Agradeço ao grande amigo que fiz nestes anos no LIM-55, Iran Amorim Silva, pessoa de grande inteligência e sempre à disposição em elaborar soluções criativas para nossos experimentos.

Ao amigo Dr. Alexandre Iscaife, quem me auxiliou nos experimentos com animais e acima de tudo, fornecendo as dicas para facilitar o caminho nesta fase.

Aos amigos Vanessa Guimarães, Isis Paloppi, Caio Moura e Ruan Pimenta, pessoas de alegria ímpar com quem aprendi não apenas diversos experimentos científicos mas também a importância da organização no laboratório. 
À Prof. Dra. Kátia Ramos Leite e Dr. Jose Pontes Junior, profissionais exemplares que me nortearam nos estudos com um amplo e notável conhecimento técnico-científico. Agradeço ainda aos Professores Miguel Srougi e William Nahas pelos anos de aprendizado vividos no Hospital das Clínicas da FMUSP.

Aos meus pais, Geralda e Milorad, que sempre torceram e me incentivaram à superar cada vez mais desafios da minha vida; sempre presentes até mesmo nos momentos mais difíceis. À minha irmã, Lígia, pessoa que tenho como modelo de virtude, dedicação e profissionalismo.

À minha namorada, Bianca, que sempre esteve ao meu lado, incentivando e acompanhando pacientemente cada etapa deste processo. 
Esta dissertação ou tese está de acordo com as seguintes normas, em vigor no momento desta publicação:

Referências: adaptado de International Committee of Medical Journals Editors (Vancouver).

Universidade de São Paulo. Faculdade de Medicina. Divisão de Biblioteca e Documentação. Guia de apresentação de dissertações, teses e monografias. Elaborado por Anneliese Carneiro da Cunha, Maria Julia de A. L. Freddi, Maria F. Crestana, Marinalva de Souza Aragão, Suely Campos Cardoso, Valéria Vilhena. 3a ed. São Paulo: Divisão de Biblioteca e Documentação; 2011.

Abreviaturas dos títulos dos periódicos de acordo com List of Journals Indexed in Index Medicus. 


\section{Sumário}

Lista de abreviaturas

Lista de tabelas

Lista de figuras

Resumo

Abstract

1. INTRODUÇÃO

1.1 Epidemiologia do Câncer de Próstata......................................... 2

1.2 Fatores prognósticos e estratégia terapêutica.............................. 3

1.3 Biologia Molecular do Câncer - Etapas essenciais....................... 5

1.4 As Metaloproteinases da Matriz............................................... 7

1.5 Estudos farmacológicos com MMPs........................................ 9

1.6 Mecanismos recentes de controle gênico - os microRNAs........... 11

1.7 Racional do trabalho................................................................ 14

2. OBJETIVOS

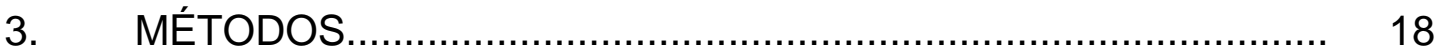

3.1 Linhagens celulares............................................................... 19

3.2 Transfecção celular.............................................................. 19

3.3 Análise da expressão do gene da MMP-9 e seus reguladores. 21

3.3.1 Extração do RNA e miRNA total................................................. 21

3.3.2 Transcrição reversa (RT) ....................................................... 21

3.3.3 Análise da expressão por real-time PCR ..................................... 22

3.3.4 Análise dos resultados............................................................. 23

3.4 Ensaios de invasão................................................................ 23

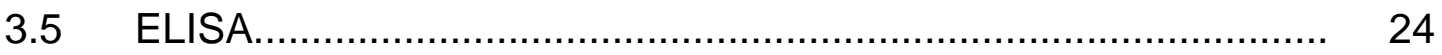

3.6 Estudos in vivo.................................................................. 24

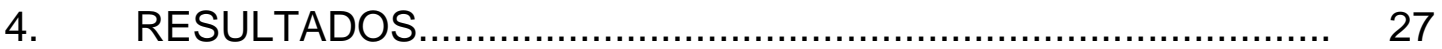

4.1 Análise da expressão de RECK/MMP-9 - miR-21 ...................... 28

4.1.1 RECK ........................................................................... 28

4.1.2 MMP-9

4.1.3 Ensaios de invasão/migração celular........................................... 31 
4.1.4 ELISA para MMP-9...................................................... 32

4.1.5 Modelo in vivo miR-21......................................................... 34

4.2 Análise da expressão de MMP-9 - miR-338-3p.......................... 41

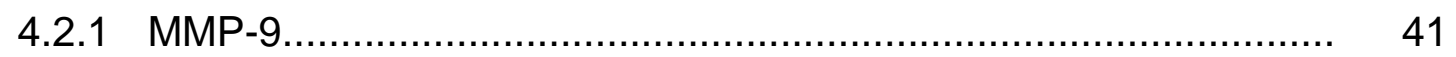

4.2.2 Ensaios de invasão celular...................................................... 42

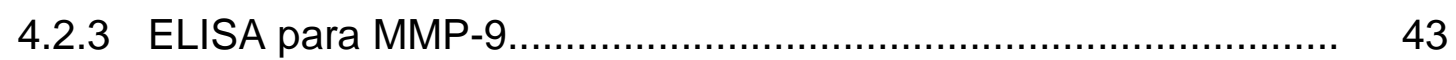

4.2.4 Modelo in vivo miR-338-3p................................................ 45

4.3 Ensaio de co-transfecção anti-miR-21 e miR-338-3p................... 50

4.3.1 Análise da expressão do RNAm de MMP-9 na co-transfecção..... 50

4.3.2 ELISA para MMP-9 na co-transfecção...................................... 52

4.3.3 Matrigel na co-transfecção...................................................... 53

4.3.4 Modelo in vivo da co-transfecção................................................. 54

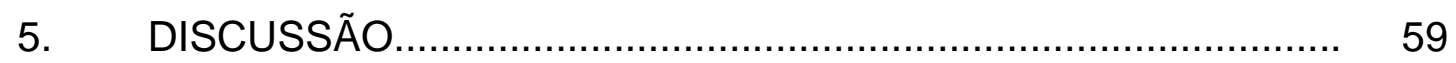

5.1 Alteração da expressão gênica de RECK e MMP-9 após transfecção do miR-21 .................................................... 60

5.2 Análise da alteração da expressão do gene e proteína alvo do

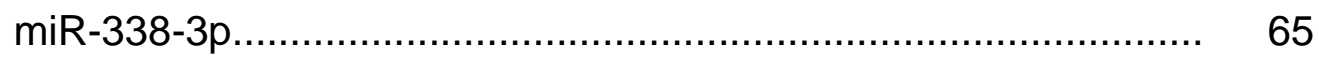

5.3 Ensaio de co-transfecção anti-miR-21 e miR-338-3p................... 71

6. CONCLUSÃO.................................................................... 74

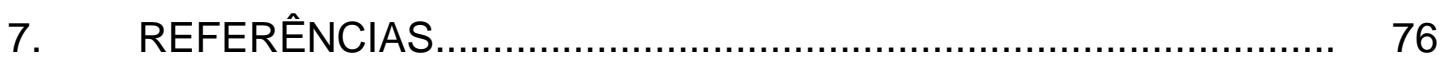

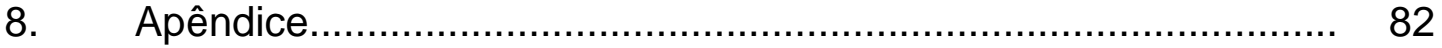




\section{Lista de abreviaturas}

CaP - Câncer de Próstata

PSA - Antígeno Prostático Específico

qRT-PCR - Reação em Cadeia de Polimerase quantitativa em tempo real

RNAm - Ácido ribonucleico mensageiro

MMP - Metaloproteinase

TIMP - Tissue Inhibitor of Matrix Metaloproteinases

miRNA - Micro RNA

CPRC - câncer de próstata resistente à castração

MEC - Matriz Extracelular

LIM 55 - Laboratório de Investigação Médica 55

ELISA - Enzyme-linked Immunosorbent Assay 


\section{Lista de Tabelas}

Tabela 1 - ELISA para MMP-9 na DU145 - miR-21 ................ 33

Tabela 2 - $\quad$ ELISA para MMP-9 na PC-3 - miR-21 ......................... 34

Tabela 3 Rotina de execução do experimento de acordo com os dias. Grupo anti-miR-21 em destaque ........................... $\quad 35$

Tabela 4 - Comparação entre razão de aumento de luminescência entre os camundongos tratados com anti-miR-21 e seus controles ............................................................... $\quad 37$

Tabela 5 - $\quad$ ELISA para MMP-9 na DU145 -miR-338-3p................... 44

Tabela 6 - $\quad$ ELISA para MMP-9 na PC3 -miR-338-3p....................... 45

Tabela 7 Rotina de execução do experimento de acordo com os dias. Grupo miR-338-3p em destaque.............................. 46

Tabela 8 - Média da razão de variação de luminescência entre os camundongos tratados com miR-338-3p e os controles... 48

Tabela 9 - ELISA para MMP-9 na DU145 - cotransfecção miR-338-

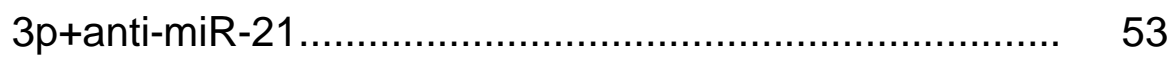

Tabela 10 - Matrigel na DU145 - cotransfecção miR-338-3p+anti-

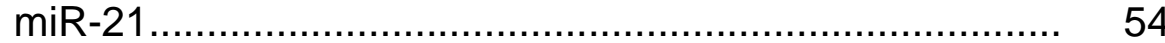

Tabela 11 Rotina de execução do experimento de acordo com os dias. Grupo miR-338-3p + anti-miR-21 em destaque........

Tabela 12 - Média da razão de variação de luminescência entre os camundongos tratados com miR-338-3p+anti-miR-21 e os controles. 


\section{Lista de Figuras}

Figura 1 - Expressão de RECK após transfecção do miR-21............ 28

Figura 2 - Expressão de RECK após transfecção miR-21 inibidor

29

Figura 3 - $\quad$ Expressão de MMP-9 após transfecção do miR-21 ............ 30

Figura 4 - Expressão de MMP-9 após transfecção do miR-21 inibidor

30

Figura 5 - Microscopia óptica do ensaio de invasão com células DU145.

Figura 6 - Número médio de células e colônias de células transfectadas com miR-21 e anti-miR-21 que invadiram a câmara inferior do meio Transwell. Linhagens DU145 e PC3.

32

Figura 7 - Evolução da Razão de Crescimento da Luminescência nos camundongos tratados com anti-miR-21 ou anti-miRnegativo

36

Figura 8 - Expressão de MMP-9 e miR-21 nos animais tratados com anti-miR-21

38

Figura 9 - Expressão de MMP-9 nos tumores extraídos dos camundongos submetidos ao tratamento com anti-miR-21 e comparados aos seus controles.

Figura 10 - Evolução da luminescência em dois camundongos tratados com anti-miR-21 (C1A1 e C1A4).

Figura 11 - Expressão de MMP-9 após transfecção com miR-338-3p..

Figura 12 - Análise da expressão de MMP9 após transfecção com miR338-3p inibidor

Figura 13 - Matrigel após transfecção com miR338-3p e anti-miR338$3 p$

Figura 14 - Fotografia de um dos campos de células da linhagem PC3 transfectadas com miR338-3p e anti-miR338$3 p$.

Figura 15 - Evolução da razão de luminescência normalizada pelo D7. Injeções de miR-338-3p ou seu controle

Figura 16 - Expressão de MMP-9 nos tumores extraídos dos animais tratados com injeções de miR-338-3p e comparados com seus controles.

Figura 17 - Relação entre a expressão de MMP-9 e miR-338-3p nos tumores extraídos dos camundongos tratados com miR338-3p.....

Figura 18 - Resultado de qRT-PCR após extração do miRNA de células DU-145 que passaram pela cotransfecão.

Figura 19 - Expressão de MMP-9 após a co-transfecção do miR-338$3 p$ e anti-miR-21. 
Figura 20 - Comparação da expressão de MMP-9 em diferentes combinações de transfecção de células DU145.

Figura 21 - Fotomicrografia do ensaio de matrigel nas células DU145 com a cotransfecção miR-338-3p+anti-miR-21

Figura 22 - Razão de aumento da luminescência normalizado pelo D14 nos camundongos tratados com combinação miR338-3p+anti-miR-21 ou controles

Figura 23 - Demonstração da Expressão de RNAm de MMP-9 em cada um dos camundongos tratados com a combinação miR-338-3p+anti-miR-21

Figura 24 - Expressão relativa de RNAm de MMP-9 nos camundongos tratados com a associação de miRNAs. 


\section{Resumo}

Ivanovic RF. Análise de miRNAs envolvidos na regulação da MMP9 e consequências processo de invasão celular do adenocarcinoma da próstata: estudo in vivo e in vitro [tese]. São Paulo: Faculdade de Medicina, Universidade de São Paulo; 2018.

INTRODUÇÃO: A propensão do $\mathrm{CaP}$ em gerar metástases decorre de mecanismos moleculares específicos em um processo composto por múltiplas etapas, sendo que o remodelamento do meio extracelular através de ações de enzimas proteolíticas denominadas metaloproteinases da matriz (MMP) é uma etapa fundamental. As MMP degradam vários componentes da matriz extracelular, sendo que seu controle pode ser exercido por outras proteínas denominadas TIMPs. Em nível gênico, outro controle pode ser exercido por moléculas chamadas microRNAs. OBJETIVO: O objetivo deste estudo é avaliar a regulação da MMP-9 por miRNAs. A partir de dados da literatura identificamos que a MMP-9 pode sofrer influência do miR-21 e 338-3p. MÉTODOS: Para os experimentos in vitro, linhagens celulares de CaP (DU145, PC3 e LNCaP) foram transfectadas com os miRNAs de interesse e a expressão de MMP-9 foi avaliada por reação em cadeia de polimerase quantitativa com transcriptase reversa (qRT-PCR). $O$ sobrenadante da transfecção foi usado para ensaios de invasão com matrigel, e ELISA. Nos experimentos in vivo, células da linhagem PC-3-luc foram implantadas no subcutâneo de camundongos Balb-c nude e tratadas com injeções de anti-miR21, miR-338-3p ou a combinação de ambos. RESULTADOS: O miR-21 aumentou expressão de MMP-9 em $72 \%$ na PC3. Houve maior invasão celular tanto na PC3 como DU145. In vivo, o bloqueio do miR-21 reduziu em $10 \%$ a expressão de MMP-9 nos tumores implantados $(p=0,04)$. O miR-338-3p reduziu a expressão de MMP-9 em 53\% na PC3 ( $p=0,001)$, 31\% na LnCaP $(p=0,23)$ e $24 \%$ na DU145 $(p=0,16)$. No ensaio de invasão, menor número de células e colônias foram capazes de invadir a membrana de matrigel. In vivo, houve redução de $27 \%$ na expressão de MMP-9 nos camundongos tratados com 0 miR-338-3p $(p=0,07)$. A combinação anti-miR-21+miR-338-3p reduz a expressão de MMP-9 em maior intensidade tanto in vitro como in vivo. CONCLUSÕES: A expressão de MMP-9 pode ser regulada pelo miR-21 e miR338-3p. O primeiro se comporta como um oncomiR ao passo que o segundo como um supressor tumoral. A combinação de miRNAs é uma estratégia plausível para ampliar o efeito sobre expressão de genes de interesse.

Descritores: neoplasias da próstata; metaloproteinases da matriz; inibidor tecidual de metaloproteinase; microRNAs; miR-21; miR-338-3p; ensaio de imunoadsorção enzimática; qRT-PCR; matrigel; proteína RECK. 


\begin{abstract}
Ivanovic RF. Analysis of miRNAs involved in the regulation of MMP9 and its consequences to cell invasion of prostate cancer: in vivo and in vitro study [thesis]. São Paulo: "Faculdade de Medicina, Universidade de São Paulo", 2018.
\end{abstract}

INTRODUCTION: The propensity of $\mathrm{CaP}$ to generate metastases results from specific molecular mechanisms in a multiphase process and the remodeling of the extracellular medium through the actions of proteolytic enzymes called matrix metalloproteinases (MMP) is a fundamental step. MMPs degrade several components of the extracellular matrix, and their control can be exerted by other proteins called TIMPs. At the gene level, another control can be exerted by molecules called microRNAs. OBJECTIVE: The objective of this study is to evaluate the regulation of MMP-9 by miRNAs. From literature data we have identified that MMP-9 may be influenced by miR-21 and 338-3p. METHODS: For in vitro experiments, CaP cell lines (DU145, PC3 and LNCaP) were transfected with the miRNAs of interest and the expression of MMP-9 was assessed by quantitative reverse transcriptase polymerase chain reaction (qRTPCR). The transfection supernatant was used for matrigel and ELISA invasion assays. For the in vivo experiments, PC3-luc cells were implanted into the subcutaneous Balb-c nude mice and treated with anti-miR-21, miR-338-3p injections or the combination of both. RESULTS: The miR-21 increased MMP-9 expression by $72 \%$ in PC3. There was greater cell invasion in both PC3 and DU145. In vivo, miR-21 blockade reduced MMP-9 expression by $10 \%$ in implanted tumors $(p=0.04)$. MiR-338-3p reduced MMP-9 expression by $53 \%$ in PC3 ( $p=0.001), 31 \%$ in LNCaP ( $p=0.23)$, and 24\% in DU145 ( $p=0.16)$. In the invasion assay, fewer cells and colonies were able to invade the matrigel membrane. In vivo, there was a $27 \%$ reduction in MMP-9 expression in mice treated with miR-338-3p ( $p=0.07)$. The combination of anti-miR-21 + miR-338$3 p$ reduces MMP-9 expression in greater intensity both in vitro and in vivo. CONCLUSIONS: MMP-9 expression can be regulated by miR-21 and miR-338$3 p$. The former behaves as an oncomyR while the second as a tumor suppressor. The combination of miRNAs is a plausible strategy to extend the effect on gene expression of interest.

Descriptors: prostatic neoplasms; matrix metalloproteinases; tissue inhibitor of metalloproteinase; microRNAs; miR-21; miR-338-3p; enzyme-linked immunosorbent assay; qRT-PCR; matrigel; RECK protein. 
1. INTRODUÇÃO 


\subsection{Epidemiologia do Câncer de Próstata}

De acordo com dados publicados pelo "SEER Program" a incidência de câncer de próstata (CaP) foi de 137 por 100.000 homens por ano no período entre 2008 e 2012. A principal faixa etária de diagnóstico deste tipo de câncer está em homens entre 65-74 anos (66 anos de idade média ao diagnóstico), sendo que cerca de $80 \%$ dos casos tem doença localizada ao diagnóstico. Contudo, apenas 12\% apresentam doença metastática para linfonodos e $4 \%$ tem metástases à distância quando a neoplasia é descoberta. O estágio no momento do diagnóstico tem influência importante na mortalidade de modo que apenas $30 \%$ dos pacientes com doença metastática terá sobrevida maior do que 5 anos. A maior taxa de mortalidade está nos homens entre 75-84 anos (80 anos de idade média no momento do óbito) (1).

No Brasil, de acordo com dados do Ministério da Saúde/INCA, a incidência do CaP saltou de 51,41 casos por 100.000 habitantes em 2006 para 62,4 casos por 100.000 habitantes em 2012. Para o biênio 2018-2019 a expectativa é de que este número chegue a 66,12 para cada 100.000 homens. Já para a mortalidade câncer específica esse número passou de 10,3 óbitos por 100.000 habitantes em 2005 para 13,9 óbitos para 100.000 habitantes em 2012. Seguindo a mesma tendência observada mundialmente as regiões com maior desenvolvimento socioeconômico (Sul e Sudeste) apresentam as maiores taxas de casos novos. Para o biênio 2018-2019 as capitais da região Sudeste devem apresentar 69,83 casos por 100.000 habitantes e o Sul 82,05 casos por 100.000. Já as regiões Norte e Nordeste estes valores serão de 39,11 e 59,35 casos por 100.000 habitantes; respectivamente 
(http://www.inca.gov.br/estimativa/2018/casos-taxas-brasil.asp).

\subsection{Fatores prognósticos e estratégia terapêutica}

Ainda há controvérsias sobre o real benefício das estratégias de rastreamento do CaP. Revisão sistemática feita com 5 estudos randomizados e controlados não revelou redução significativa da mortalidade câncer específica. Contudo, homens submetidos ao rastreamento foram mais frequentemente diagnosticados com CaP e além disso estavam em estágios localizados. Entretanto, o grupo no qual foi realizado rastreamento foi submetido a formas de tratamento desnecessários com maior frequência do que os não rastreados (2). Faria et al conduziram estudo na população brasileira comparando um grupo de pacientes com $\mathrm{CaP}$ diagnosticado por rastreamento com outro composto por pacientes com esta neoplasia, mas que foram referenciados para tratamento. Os autores mostraram que pacientes submetidos ao rastreamento tinham PSA mais baixo $(5,5 \mathrm{ng} / \mathrm{mL} \times 10,0 \mathrm{ng} / \mathrm{mL})$, menor frequência de classificação de Gleason $\geq 7(34 \%$ x 46\%), menor incidência de metástases à distância $(3 \% \times 9,3 \%)$ e maior frequência de tumores localizados $(54,2 \% \times$ $67,7 \%)(3)$.

Nesse sentido tem sido recomendado pela sociedade europeia para 0 tratamento do paciente com $\mathrm{CaP}$ de baixo risco e diagnosticado por modalidade de rastreamento a vigilância ativa (active surveillance) e, nos casos que não se cogita tratamento curativo; o Watchful Waiting. A primeira forma tem o objetivo de adiar o tratamento com intenção curativa até o momento em 
que apareçam indícios de doença ameaçadora à vida do paciente. O objetivo é evitar tratamentos desnecessários e as complicações decorrentes dele. Um estudo com seguimento de longo prazo avaliando os resultados da vigilância ativa para pacientes de baixo risco revelou que esta pode ser uma estratégia segura, garantindo boas taxas de sobrevida. A sobrevida câncer específica em 10 e 15 anos é de $98,1 \%$ e $94,3 \%$, respectivamente. A taxa de pacientes que desenvolveram metástases foi de $2,8 \%$ e a mortalidade câncer especifica foi de $1,5 \%$, apesar de que $27 \%$ dos pacientes foram submetidos a tratamento radical (4). Já a segunda modalidade (Watchful waiting) tem uma proposta diferente uma vez que não tem intenção curativa da doença. Contudo, o conceito de se adiar o tratamento como forma de evitar complicações permanece (5).

Para o CaP metastático virgem de tratamento a opção inicial baseia-se inicialmente no bloqueio androgênico ( $A D T$ - androgen deprivation therapy) obtido através da castração cirúrgica (orquiectomia) ou química (análogos ou antagonistas do $\mathrm{GnRH}$ ) o qual invariavelmente perde eficácia após alguns anos, permitindo que a neoplasia de próstata continue a se desenvolver à despeito de níveis séricos reduzidos de testosterona (6).

Nos estágios que o tumor se torna resistente à castração uma evolução mais sombria é descrita, com taxas de metástases ósseas maiores que $84 \%$ e com possibilidade de surgimento em até 2 anos de $33 \%$. Para o tumor resistente à castração (Castrate Resistant Prostate Cancer - CRPC) a sobrevida mediana é de 9 a 30 meses e o metastático de 9 a 13 meses (7).

A cura pela terapia de supressão de testosterona é difícil, dado que menos de $5-10 \%$ dos pacientes estarão vivos após 10 anos do tratamento. 
Alguns mecanismos propostos para essa independência à testosterona estão na produção adrenal e intracelular do hormônio, bem como na modificação da expressão dos receptores de andrógenos e também ativação de receptores de glicocorticóides e danos às vias de reparação de DNA. Por conta de tais mecanismos, duas novas drogas para terapia em pacientes portadores de CaP resistente à castração são atualmente utilizadas e atuam na redução da produção intracelular de andrógenos (abiraterona) ou no bloqueio do receptor de andrógenos (enzalutamida) (8). Além delas, outras drogas que atuam de diferentes formas que não sejam a redução intracelular de hormônios ou antagonizando o receptor de andrógeno já foram liberadas para tratamento do CaP metastático resistente à castração. São exemplos o Sipuleucel-T (vacina composta de células mononucleares autólogas) ou o Rádio-223 (um emissor de radiação alfa de curta ação com seletividade para áreas metastáticas e que promove a quebra do DNA dupla fita das células de CaP) (9). Apesar delas, a sobrevida pode ser prorrogada em alguns meses e por conta disso, outras terapias baseadas na ação ao nível molecular de certas drogas precisam ser estudadas para se ampliar o arsenal terapêutico dos pacientes com $\mathrm{CaP}$ resistente à castração.

\subsection{Biologia Molecular do Câncer - Etapas essenciais}

Aspectos fundamentais para o desenvolvimento das neoplasias envolvem algumas etapas como dano aos genes reguladores (protooncogenes, genes supressores tumorais, genes reguladores de apoptose e 
genes de reparo do DNA) (10). Tais alterações podem levar à distúrbios em campos da fisiologia celular como por exemplo: manutenção dos sinais para proliferação celular, perda da regulação de supressores do crescimento, evasão da inibição do crescimento por contato, desregulação dos mecanismos de apoptose, aquisição de imortalidade replicativa, indução de angiogênese, ativação de mecanismos de invasão e metástase, modificação do metabolismo, evasão dos sistema imune e interação com estroma. Cada um destes mecanismos confere um amplo campo de estudo da biologia molecular do câncer (11).

De um modo geral os tumores metastáticos ainda são responsáveis pela maior mortalidade relacionada às neoplasias, o que confere grande importância em se estudar os mecanismos moleculares envolvidos neste evento (12). 0 surgimento de metástases pode se iniciar a partir de uma "assinatura genética" presente nas células do tumor primário e que confere a elas potencial metastático. A partir disto clones destas células se desenvolvem, adquirindo características necessárias para invasão, sobrevivência no sistema circulatório até o implante e crescimento no sítio secundário (13).

A propensão do CaP em gerar metástases decorre de mecanismos moleculares específicos em um processo composto por múltiplas etapas. 0 desenvolvimento de metástases à distância se inicia com o processo de invasão local através de mecanismos importantes que são a perda da capacidade de ligação entre as próprias células e entre elas e a matriz extracelular. Na primeira ocorre redução da expressão do complexo Ecaderina-B-catenina; num processo conhecido como transição epitélio- 
mesenquimal (14). Paralelamente, as células precisam migrar pela matriz extracelular para em seguida romper a membrana basal e atingir os vasos sanguíneos através dos quais serão levadas para os sítios secundários. Basicamente, esta migração é feita por células únicas (invasão celular única) ou coletivamente (invasão coletiva). Em ambas as formas de invasão, as células têm como características principais a perda de polaridade celular e o processo de transição epitélio-mesenquimal. Além disso, estas células emitem projeções devido a reorganização do citoesqueleto de actina e remodelam o meio extracelular através de ações de enzimas proteolíticas denominadas metaloproteinases da matriz (MMP) (15). As MMP degradam a matriz extracelular (MEC) e membrana basal. Após, sucedem-se outros eventos importantes como adesão das células malignas às células endoteliais, seguida de migração e desenvolvimento no sítio secundário utilizando interações moleculares específicas.

\subsection{As Metaloproteinases da Matriz}

As MMP são proteínas pertencentes a uma família de enzimas proteolíticas ou endoproteinases que degradam vários componentes da matriz extracelular (MEC) (16). Elas têm papel importante em muitos eventos biológicos como cicatrização, angiogênese, inflamação, embriogênese e até mesmo câncer. As MMPs em geral são compostas por quatro regiões: pródomínio, domínio catalítico, uma região de dobra (“hinge region”) e um domínio hemopexina. Elas podem ser secretadas a partir das células ou ancoradas à 
membrana plasmática e são divididas em seis grupos (colagenases, gelatinases, estromelisinas, matrilisinas, MMPs de membrana e um último grupo sem classificação) (16).

A atividade das MMP é regulada por inibidores endógenos conhecidos como TIMPs (Tissue Inhibitors of Matrix Metalloproteinases). Elas são proteínas com peso molecular entre $21-29 \mathrm{kDa}$ e até hoje 4 delas foram descritas em vertebrados (TIMP-1, TIMP-2, TIMP-3 e TIMP-4) (16). Cada uma consiste de um domínio $\mathrm{N}$-terminal responsável pela atividade inibitória da MMP, e um domínio C-terminal. Embora todas as TIMPs liguem-se firmemente à maioria das MMP, elas possuem diferentes atividades inibitórias contra diferentes MMPs (17).

As MMPs são também reguladas em níveis transcripcional e pós transcripcional. A expressão da maioria das MMPs é baixa em tecidos normais e elevada quando há remodelamento. A expressão pode ser induzida por citocinas, fatores de crescimento, agentes químicos, estresse físico, oncogenes e interações com a matriz extracelular (18). As MMP ampliam o processo de invasão tumoral não só através da degradação das proteínas da MEC, como também ativando as cascatas de transdução de sinal que promovem motilidade e a solubilização de fatores de crescimento ligados à MEC (19).

Nos últimos anos vários estudos foram publicados envolvendo a expressão gênica das MMPs e seus reguladores em várias neoplasias (20-23) de tal forma que as MMPs afetam não somente a invasão celular, mas também o comportamento celular e progressão tumoral (24).

No CaP, diversos estudos procuraram estabelecer associações entre a 
neoplasia e a expressão das metaloproteinases e/ou seus inibidores. Muitos deles focaram no uso destas enzimas como marcadores de atividade da doença e/ou prognóstico (25-31). Outros corroboraram a teoria de que o desequilíbrio entre MMPs e TIMPs é identificada em tumores malignos, podendo explicar o comportamento mais agressivos de alguns deles (32).

O Laboratório de Investigação Médica 55 da Faculdade de Medicina da USP (LIM-55) tem nos últimos anos focado no estudo das metaloproteinases em neoplasias urológicas. Em 2009, Reis et al demonstraram que polimorfismos das regiões promotoras das MMPs podem estar relacionadas ao prognóstico de pacientes com CaP (33). Em 2011, os mesmos autores, estudando amostras de espécimes cirúrgicos de pacientes submetidos a prostatectomia radical por neoplasia maligna da próstata identificaram que MMP-9 estava hiperexpressa em mais de $9 x$ nos tecidos que continham neoplasia. Além disso, a maior expressão desta MMP estava relacionada aos níveis de PSA acima de $10 \mathrm{ng} / \mathrm{mL}$ (34). A maior expressão de MMP-2 também ocorre em tecidos malignos de próstata com escores de Gleason mais avançados (35).

\subsection{Estudos farmacológicos com MMPs}

No passado alguns estudos de fase I testaram o uso de inibidores de metaloproteinases. O Marimastat, um inibidor de metaloproteinase para ser administrado por via oral não apresentou mudanças nos níveis de MMP-2 e MMP-9 sanguínea detectados por zimografia em pacientes com neoplasia 
avançada de pulmão (36). Já em 2001, outro medicamento; o MMl270 também em estudo fase I com pacientes portadores de diferentes tipos de neoplasias sólidas avançadas não demonstrou redução tumoral, porém foi visto estabilidade $\geq 90$ dias além de uma elevação dos níveis de TIMP-1 (37). Resposta tumoral com outro inibidor, BMS-275291, não foi observada em estudo fase I entre pacientes com câncer coloretal ou pulmão (38). Já em 2007, uma nova droga estudada em pacientes portadores de diferentes tipos de neoplasias sólidas (pulmão, melanoma, GIST, sarcoma, intestino e outras); a S-3304 comprovou redução da atividade de MMP-2 e MMP-9 detectada por zimografia in situ (diferentemente dos estudos anteriores) apesar de não ter sido relatada resposta tumoral (39). Um único estudo fase II testou a ação de um análogo da tetraciclina na inibição da MMP-2 e MMP-9 em regime oral em pacientes portadores de sarcoma, porém nenhum paciente apresentou redução da neoplasia (40).

Os estudos anteriores focaram no uso de medicamentos atuando diretamente nas MMPs. Estas são proteínas e, portanto; codificadas por genes específicos, sendo necessários as etapas de transcrição e tradução até que as proteínas estejam efetivamente prontas para atuarem. Pode ser que a falta de resposta objetiva nos estudos anteriores se deva ao fato que as MMPs tenham seus genes regulados por mecanismos adicionais. 


\subsection{Mecanismos Recentes de Controle Gênico - os Micro RNAs}

Nos últimos anos um novo mecanismo de controle gênico tem sido objeto de estudo de muitos pesquisadores, é a chamada interferência de RNA (RNAi). Interesse nesta área de pesquisa tem sido intenso pois demonstra uma mudança de paradigma no tratamento do câncer: enquanto tradicionalmente (e ainda hoje) as drogas anticâncer atuam de maneira citotóxica e, desta forma sem distinguir células saudáveis das não saudáveis; pesquisas que envolvem o estudo do RNAi tentam atuar nas vias moleculares que se apresentam desreguladas nas células neoplásicas; potencialmente poupando as células saudáveis (41). Algumas moléculas são responsáveis por este modelo de regulação: siRNA (small interfering RNA), shRNA (short hairpin RNA), piRNA (Piwi-interacting RNA) e miRNA (microRNA) (42). Todas estas são moléculas pequenas de RNAs chamadas genericamente de scRNA (small non-conding $R N A s)$.

O mecanismo de RNAi é um mecanismo de defesa celular evolucionalmente conservado e se caracteriza pelo silenciamento gênico pós transcripcional de moléculas de RNA dupla fita ou fita simples (43), sendo que a ação dos miRNA é um dos temas mais estudados.

MiRNA são pequenas moléculas endógenas de fita simples, não codificadoras de proteínas, constituídas por 19-25 nucleotídeos que fazem parte de uma nova classe de reguladores pós-transcripcionais da expressão gênica. Enquanto a maioria dos miRNA são codificados em regiões específicas do genoma, cerca de $30 \%$ estão localizados em íntrons de genes codificadores 
de proteínas (44). Estes lócus são os responsáveis por codificar a molécula primária dos miRNAs (pri-miRNA) e sendo assim, mutações ou deleções poderão afetar os níveis das moléculas maduras de miRNA e com isso favorecer o desenvolvimento de neoplasias. Exemplos destas alterações ocorrem na Leucemia Linfocítica Crônica tipo B (deleção do 13q14) ou mutações de ponto no gene do pri-miR-128 (Leucemia Linfoblástica Aguda). Alterações da transcrição de pri-miRNA podem ocorrer por influência de fatores supressores tumorais ou alterações epigenéticas como hipermetilação (44).

Após a transcrição e ainda no núcleo, os pri-miRNA são clivados por uma associação de duas enzimas, DROSHA e DGCR8 (DiGeorge syndrome critical region 8), formando os miRNAs precursores (pre-miRNA). Estes são enviados ao citoplasma por uma enzima chamada exportina 5 (XPO5). Então, outra enzima - DICER I - cliva a molécula pre-miRNA para gerar o miRNA maduro. Uma das fitas desta última liga-se à proteína Argonauta para integrar o complexo RISC que irá ao final complementar-se às moléculas alvo de RNA mensageiro (RNAm), levando ao silenciamento gênico (44).

Os miRNAs exercem seus efeitos regulatórios ligando-se à região 3' não traduzida do RNAm alvo. Em mamíferos, em geral ocorre um pareamento imperfeito com o RNAm acarretando uma inibição traducional do alvo. Os miRNAs possuem sequências pequenas e agem sem a necessidade de pareamento completo. Um único miRNA pode regular muitos RNAm-alvo, além de cooperarem no controle de um mesmo RNAm (45).

O genoma humano tem milhares de genes e um mesmo miRNA pode regular diversos deles. Desta forma foi necessário o desenvolvimento de ferramentas de bioinformática capazes de prever onde pode haver uma 
complementaridade entre gene alvo e o miRNA. A predição de complementaridade entre uma molécula de miRNA e a de RNAm do gene alvo depende de três fatores (46).

a. Complementaridade entre a molécula de miRNA e a região 3'UTR (untranslated 3'end - região 3'não traduzida).

b. A energia livre da ligação entre as moléculas de miRNA/RNAm. Quanto mais baixa a energia livre, mais estável será a ligação.

c. Se o sítio de ligação entre um RNAm e o miRNA é conservado entre espécies. Quando a complementaridade é evolucionalmente mantida, então é maior a probabilidade de a predição de ferramenta de bioinformática não ser um falso positivo

Importante ainda enfatizar que dentro da molécula de miRNA existe uma região na posição 5' composta pelos nucleotídeos 2 ao 7 chamada de "seed region". A complementaridade das regiões 5' e 3' da molécula de miRNA é classificada em três tipos de pareamento: canônico, 3'-suplementar e 3'compensatório. Os sítios canônicos são responsáveis pela maioria da conservação dos alvos entre as espécies e apresentam um pareamento perfeito dos sete nucleotídeos da posição 5' da molécula de miRNA com a molécula de RNAm. O pareamento canônico é o principal componente para a interação miRNA-RNAm, mas o pareamento adicional de 3 a 4 nucleotídeos na posição 3' (chamado de suplementar) é importante para aumentar o efeito desta interação. O pareamento compensatório é aquele que ocorre entre 3 a 4 nucleotídeos da posição 3' quando não ocorre o pareamento perfeito na "seed 
region" (47).

Sendo os miRNAs responsáveis pela regulação de diversos processos biológicos, não seria impossível de imaginar que tais moléculas também poderiam estar relacionadas ao controle das enzimas envolvidas no processo de metástase, ou em outras palavras; na regulação das metaloproteinases ou de seus reguladores (TIMPs).

O estudo das MMPs e seus reguladores já tem sido foco de trabalho no Laboratório de Investigação Médica 55 da Faculdade de Medicina da USP (LIM55). Já foi demonstrado que a expressão de MMP-9 em espécimes cirúrgicos obtidos de pacientes submetidos a prostatectomia radical era aumentada, ao passo que duas de suas proteínas reguladoras, TIMP-1 e RECK; apresentavam-se reduzidas (34).

Contudo, o primeiro trabalho do LIM55 avaliando a regulação de MMPs por miRNAs demonstrou que em linhagens celulares de CaP o miR-21 poderia regular negativamente a expressão da proteína RECK. Esta por sua vez age inibindo a MMP-9. Desta forma, o aumento dos níveis de miR-21 levaria indiretamente à elevação dos níveis de MMP-9. Em cerca de $91 \%$ dos pacientes com estádio patológico T3 cujos espécimes cirúrgicos foram obtidos após prostatectomia radical apresentavam perfil de superexpressão de MMP-9 e subexpressão de RECK (48).

\subsection{Racional do trabalho}

A busca por miRNAs capazes de influenciar a expressão da MMP-9 tem relevância no sentido de se explorar novas possibilidades terapêuticas no CaP 
metastático.

Trabalho anterior do LIM-55 (48) mostrou que o miR-21 poderia interferir nos níveis de MMP-9 indiretamente através da regulação da proteína RECK. Impulsionados pela possibilidade de que miRNAs poderiam agir sinergisticamente (49) procuramos outro miRNA que poderia ter como alvo a MMP-9. Em 2011, Huang et al demonstraram que o miR-338-3p poderia regular negativamente a expressão de MMP-9 no câncer hepático (50). Desta forma optamos por escolher estes dois miRNAs (miR-21 e miR-338-3p) como candidatos para testar a regulação da MMP-9 isolada e de forma combinada.

Em resumo, o objetivo deste estudo é avaliar a regulação da metaloproteinase 9 (MMP-9) por miRNAs. A partir de dados da literatura e ferramentas de bioinformática identificamos que a MMP-9 pode ser influenciada pelo miR-21 e 338-3p. 
2. OBJetivos 
Analisar o papel dos miR-338-3p e miR-21 na regulação da MMP-9 bem como a consequência desta regulação na invasão celular em estudos in vitro de linhagens de CaP expostas a estes miRNAs e a seus antagomir.

Estudar o efeito da administração dos miR-21 e miR-338-3p e de seus antagomiRNAs em modelo in vivo de CaP metastático. 
3. MÉtodos 


\subsection{Linhagens Celulares}

As seguintes linhagens celulares de CaP obtidas no American Type Culture Collection (ATCC) foram utilizadas neste trabalho: LNCaP, (provenientes de metástases linfonodais), DU145 (proveniente de metástase cerebral), PC3 (proveniente de metástase óssea de portadores de CaP) e PC3M-luc-C6 para os experimentos in vivo.

As linhagens foram acondicionadas em frascos de cultura de $25 \mathrm{~cm}^{2}$ contendo RPMI-1640, DMEM ou MEM dependendo do tipo celular, suplementado com soro fetal bovino (SFB) a $10 \%$ e solução antibiótica e antimicótica (Sigma Co, St. Louis, MO, EUA) a 1\%. Os frascos foram mantidos em estufa para cultura de células contendo atmosfera úmida composta por $95 \%$ de ar e $5 \%$ de $\mathrm{CO}_{2}$ a temperatura de $37^{\circ} \mathrm{C}$. O meio de cultivo foi trocado quando atingido o estado de subconfluência em monocamada ( $70 \%$ da área cultivável recoberta por células).

\subsection{Transfecção celular}

Um dia antes da transfecção as linhagens celulares foram deixadas em um meio livre de antibiótico. As linhagens celulares foram então transfectadas com aproximadamente 100nM de miR-338-3p, anti-miR-338-3p, miR-21, antimiR-21 e seus respectivos miRNA controles (miR-negativo e também com miRNA antagonista negativo; o anti-miR negativo) (Ambion, Austin, TX, USA). Pré-miR, anti-miR e seus respectivos controles foram diluídos em $50 \mu \mathrm{L}$ de meio OPTI-MEM I em diferentes tubos em uma concentração final de 50nM 
(2,5 $\mathrm{L}$ da solução de $10 \mu \mathrm{M})$, A seguir $1,5 \mu \mathrm{L}$ do agente de Transfecção siPORT NeoFX (AMBION, USA) foi diluído em 50 $\mu$ L de meio OPTI-MEM I em um tubo.

As diluições dos pré-miR e do agente de transfecção foram combinadas e posteriormente incubadas por 10 minutos em temperatura ambiente para formação do complexo de transfecção. O mesmo procedimento foi realizado com os miR-negativo e anti-miR negativo. A seguir, $100 \mu \mathrm{L}$ do complexo de transfecção foram dispensados em cada poço de uma placa de cultura de 12 poços limpa onde cada amostra de complexo de transfecção foi configurada e marcada de acordo com seus controles (miR-negativo e anti-miR negativo). As células em suspensão foram transferidas e semeadas na cavidade dos poços da placa de cultura para sobreposição dos complexos de transfecção em um volume de $400 \mu \mathrm{L}$ de meio de cultura contendo $5 \times 10^{4}$ de células/poço.

Em seguida, a placa foi encubada em estufa de $\mathrm{CO}_{2}$ à $37^{\circ} \mathrm{C}$ por $24 \mathrm{~h}$. Posteriormente, as células aderidas foram removidas das placas de cultura com tripsina/EDTA e então a suspensão celular foi lavada com meio RPMI $10 \%$, centrifugada a $4000 \mathrm{rpm}$ por $5 \mathrm{~min}$.

Após a transfecção foi feita análise da expressão dos miRNAs para comprovação da transfecção por qRT-PCR. A análise da expressão dos genes alvos também foi feita por qRT-PCR. Já as análises da expressão da proteína MMP-9 foram feitas por ELISA. Além disso, fizemos análises de invasão celular para verificar a consequência da inibição dos genes alvos. 


\subsection{Análise da expressão do gene da MMP-9 e seus reguladores}

\subsubsection{Extração do RNA e miRNA total}

O RNA e miRNA total foram extraídos com o uso do Kit mirVana (Ambion, Applied Biosystems). As células foram tripsinizadas e centrifugadas, sendo suspensas em $200 \mu \mathrm{L}$ de solução de lise, $200 \mu \mathrm{L}$ de etanol a $64 \%$, com homogeneização em vórtex. A solução foi então transferida para o filtro, centrifugadas a $14.000 \mathrm{rpm}$ por $1 \mathrm{~min}$ e depois foram feitas lavagens com soluções próprias do kit. No intervalo das lavagens as amostras eram submetidas à centrifugação. Ao final o RNA e miRNA foram diluídos em $50 \mu \mathrm{L}$ de solução de eluição pré-aquecida $\left(80^{\circ} \mathrm{C}\right)$ livre de RNase/DNase. A pureza e concentração do RNA e miRNA foram mensuradas em nanodrop (260/280 nM).

\subsubsection{Transcrição reversa (RT)}

A síntese do cDNA foi realizada a partir de 5ng de RNA utilizando-se a enzima MultiScribe ${ }^{\mathrm{TM}}$ transcriptase reversa e iniciadores randômicos (Applied Biosystems). Resumidamente, o RNA total era diluído em $\mathrm{H}_{2} \mathrm{O}$ livre de nucleases em um volume final de $10 \mu \mathrm{L}$. A este volume foram acrescentados $2 \mu \mathrm{L}$ de oligonucleotídeos randômicos (10X), 0,8 $\mu \mathrm{L}$ do mix de dNTPs (100 mM), $2 \mu \mathrm{L}$ do tampão da enzima (10X) e 4,2 $\mu \mathrm{L}$ de água RNA/DNA nuclease free. As soluções eram então submetidas a ciclos de temperaturas: 10 min a $25^{\circ} \mathrm{C}, 120 \mathrm{~min}$ a $37^{\circ} \mathrm{C}$ e 5 min a $85^{\circ} \mathrm{C}$. Após o término dos ciclos o cDNA foi armazenado a $-20^{\circ} \mathrm{C}$ até o uso. Já a confecção do cDNA do miRNA foi 
realizada pegando-se $200 \mathrm{ng}$ de miRNA diluídos em $20 \mu \mathrm{L}$ de água. À uma quantidade de $3 \mu \mathrm{L}$ desta solução, foram adicionados $7 \mu \mathrm{L}$ da combinação de agentes do kit miRNA TaqMan®miRNA Reverse Transcription Kit (Applied Biosystems, Foster City, CA): $0,15 \mu \mathrm{L}$ de DNTP mix, $0,5 \mu \mathrm{L}$ da transcriptase reversa, $1,5 \mu \mathrm{L}$ de tampão, $0,19 \mu \mathrm{L}$ inibidor de RNAse, 3,66 $\mu \mathrm{L}$ de água livre de nuclease e $1 \mu \mathrm{L}$ do primer com a sequência específica do miRNA, totalizando $10 \mu \mathrm{L}$ cDNA. Os ciclos de temperatura foram usados nos seguintes parâmetros: $30 \min$ à $16^{\circ} \mathrm{C}, 30 \min$ à $42^{\circ} \mathrm{C}$ e $5 \min$ à $85^{\circ} \mathrm{C}$.

\subsubsection{Análise da expressão por Real-Time PCR}

Os primers utilizados para amplificação dos genes foram desenhados com o auxílio do programa PrimerExpress (Applied Biosystems, California, USA), o qual desenha primers com as características necessárias para os experimentos de Real Time PCR no termociclador ABI 7500 Fast.

Para quantificação das amostras utilizamos o reagente TaqMan® (Applied Biosystems, California, USA). Este protocolo utiliza dois iniciadores não fluorescentes e uma sonda com dupla marcação que se anela à região localizada entre os iniciadores. Esta marcação dupla é formada por um fluoróforo que emite luz quando excitado e um quencher que absorve a luz emitida pelo fluoróforo. Durante os ciclos da PCR, a sonda é quebrada pela Taq polimerase na etapa de extensão do iniciador anelado. Esta quebra da sonda elimina a absorção pelo quencher da fluorescência emitida que pode ser então medida através de uma câmera situada na parte superior do equipamento. A quantificação da emissão absorvida pela câmera após quebra 
da sonda permite então a detecção do produto do PCR em tempo Real. As reações ocorreram nas seguintes concentrações: $0,5 \mu \mathrm{L}$ do primer específico, 5 $\mu \mathrm{L}$ de TaqMan® Universal PCR máster mix (Applied Biosystems, CA, EUA), 3,5 $\mu \mathrm{L}$ de água livre de nuclease RNA e $1 \mu \mathrm{L}$ de cDNA. As condições dos ciclos do termociclador foram: 2 min à $50^{\circ} \mathrm{C}, 10$ min à $95^{\circ} \mathrm{C}$ e 40 ciclos de 15 segundos à $95^{\circ} \mathrm{C}$ e 1 minuto à $60^{\circ} \mathrm{C}$. Todas as reações foram realizadas em duplicata, tendo como controle endógeno o $\beta 2 \mathrm{M}$ (para os genes) e o RNU43 (para miRNA).

\subsubsection{Análise dos resultados}

O nível de expressão dos genes alvo foi obtido pela quantificação relativa e dos níveis de expressão em vezes determinado pelo método $2^{-\Delta \Delta c t}$ (51).

\subsection{Ensaios de invasão}

Utilizamos câmaras bipartites do tipo Transwell (Corning®), utilizando filtros com poros de $8 \mu \mathrm{m}$ em placas de 24 poços. Para o ensaio de invasão, a câmara era coberta com $50 \mu \mathrm{L}$ de Matrigel diluído em meio de cultura livre de soro (1:2). As células após serem mantidas $24 \mathrm{~h}$ em meio de cultura sem SFB, eram tripsinizadas e ressuspendidas em número de $3 \times 10^{4}$ células $/ \mathrm{ml}$ em meio de cultura sem soro. Essas células foram adicionadas na câmara superior sobre o Matrigel ao passo que na câmara inferior foram adicionados $750 \mu \mathrm{L}$ de

meio de cultura contendo SFB. A placa era coberta e mantida em estufa de 
$\mathrm{CO} 2$ por $48 \mathrm{~h}$ a $37^{\circ} \mathrm{C}$. Após este período, o meio da câmara superior foi armazenado para zimografia. As células que não invadiram eram removidas, e as células que passaram para a câmara inferior foram fixadas com formaldeído em PBS (4\%) e coradas com solução de cristal violeta (2\%) em metanol, imagens de cada membrana foram adquiridas para determinação do número de células que invadiram através de contagem. Cada experimento foi realizado em triplicata para garantia dos resultados.

\subsection{ELISA}

Para o ensaio de ELISA (DMP900 - R\&D Systems, Minneapolis, MN, EUA) com MMP-9 a detecção da proteína foi realizada com o meio condicionado das células transfectadas com o miR agonista, anti-miR, bem como os seus respectivos controles positivos e negativos de acordo com as instruções do fabricante. O primeiro passo para a realização da técnica de ELISA é fazer a diluição do padrão. Essa diluição seriada funciona como um controle do método. Ao final da leitura se os marcadores padrões apresentarem um perfil desejado é sinal que a técnica foi realizada de forma correta. Após todas as etapas descritas no protocolo realizamos a leitura em leitor de ELISA a $450 \mathrm{~nm}$.

\subsection{Estudos in vivo}

Os experimentos com os animais seguiram as normas éticas 
preconizadas pelo Comitê de Ética e Pesquisa Animal da FMUSP ( $\left.{ }^{\circ} 017 / 15\right)$. Camundongos machos Balb/c atímicos de 5-7 semanas obtidos no Biotério Central da FMUSP foram anestesiados por exposição a isoflurano a $3 \%$. No dia zero do experimento, $1.5 \times 10^{6}$ células da linhagem PC3M-luc-C6 suspendidas em $80 \mu \mathrm{L}$ de meio de cultura sem antibiótico eram injetadas no subcutâneo do flanco dos camundongos. As células PC3M-luc-C6 são derivadas da linhagem celular de CaP PC3M e apresentam a expressão constitutiva de um plasmídeo que contém o gene da enzima luciferase. Esta converte seu substrato, a luciferina, em oxiluciferina em uma reação capaz de liberar energia luminosa. A reação depende de ATP, implicando que apenas células viáveis irão efetivamente emitir o sinal luminoso (52).

Para o experimento in vivo, os camundongos foram divididos nos seguintes grupos:

Animais tratados com injeção de anti-miR-21

Animais controle tratados com injeção de anti-miR negativo

Animais tratados com injeção de miR-338-3p

Animais controle tratados com injeção de miR-negativo

Animais tratados com injeção combinada de anti-miR-21+miR-338-3p

Animais controle tratados com injeção de anti-miR negativo+miRnegativo.

No D0, o sucesso da inoculação das células no flanco dos camungondos era comprovada por exame de bioluminescência in vivo (IVIS Xenogen - IVIS® Spectrum), bem como a evolução do crescimento; a qual foi feita periodicamente com a mesma técnica.

Na preparação das soluções de miRNA cada dose do tratamento tinha 
volume final de $50 \mu \mathrm{L}$, tendo sido preparada da seguinte forma: $3 \mu \mathrm{L}$ de uma solução de estoque à $20 \mathrm{nM}$ contendo o miRNA $(2 \mu \mathrm{g})$ eram combinadas com $22 \mu \mathrm{L}$ de PBS, totalizando $25 \mu \mathrm{L}$. À este volume eram combinados $25 \mu \mathrm{L}$ de atelocolágeno, centrifugados à $10.000 \mathrm{rpm}$ por 1 minuto à $4^{\circ} \mathrm{C}$. Ao final, a solução era mantida em rotação lenta por 20 minutos à $4^{\circ} \mathrm{C}$. Cada animal recebia um total de três injeções com intervalo de 4 ou 5 dias entre elas.

Para os grupos de animais tratados com combinação de miRNA (grupo anti-miR-21+miR-338-3p e anti-miR negativo+miR negativo) foi mantido volume final de $50 \mu \mathrm{L}$ de cada injeção, tendo sido reduzido o volume de PBS para $19 \mu \mathrm{L}$.

As aplicações eram feitas com seringas de insulina com agulha de 0,3mm diretamente no tumor, tendo sido realizadas no Centro de Bioterismo da FMUSP com os camundongos anestesiados com isoflurano $3 \%$.

Ao final do tratamento, os camundongos eram acompanhados por 7 a 10 dias, realizando ao menos dois controles de imagem com exames de bioluminescência. Após este período os animais foram eutanasiados em câmara de CO2. As carcaças dos animais eram descartadas conforme o capítulo de Resíduos Infectantes do manual do LIM-HC-FMUSP.

Parte do tumor foi congelada em freezer $-80^{\circ}$ C para análise da expressão do gene alvo (MMP-9) e extração dos miRNAs injetados como descrito acima. 
4. Resultados 


\subsection{Análise da expressão de RECK/MMP-9 - miR-21}

\subsubsection{RECK}

As células da linhagem PC3 mostraram uma redução de 48\% na expressão de RECK ao serem expostas ao miR-21 quando comparadas ao grupo controle $(p=0,03)$. Observando as demais linhagens, DU145 e LNCaP, constatamos que não houve menor expressão de RECK pelo grupo transfectado com o miR-21 (Figura 1). Cumpre salientar que a inibição da RECK pelo miR-21 na DU145 foi comprovada em publicação prévia do LIM-55 da Faculdade de Medicina da USP (48). Já quando foi feito o bloqueio do miR21 houve elevação dos níveis de RECK em todas as linhagens, sendo estatisticamente significativa em duas delas; DU145 e PC3 (Figura 2).

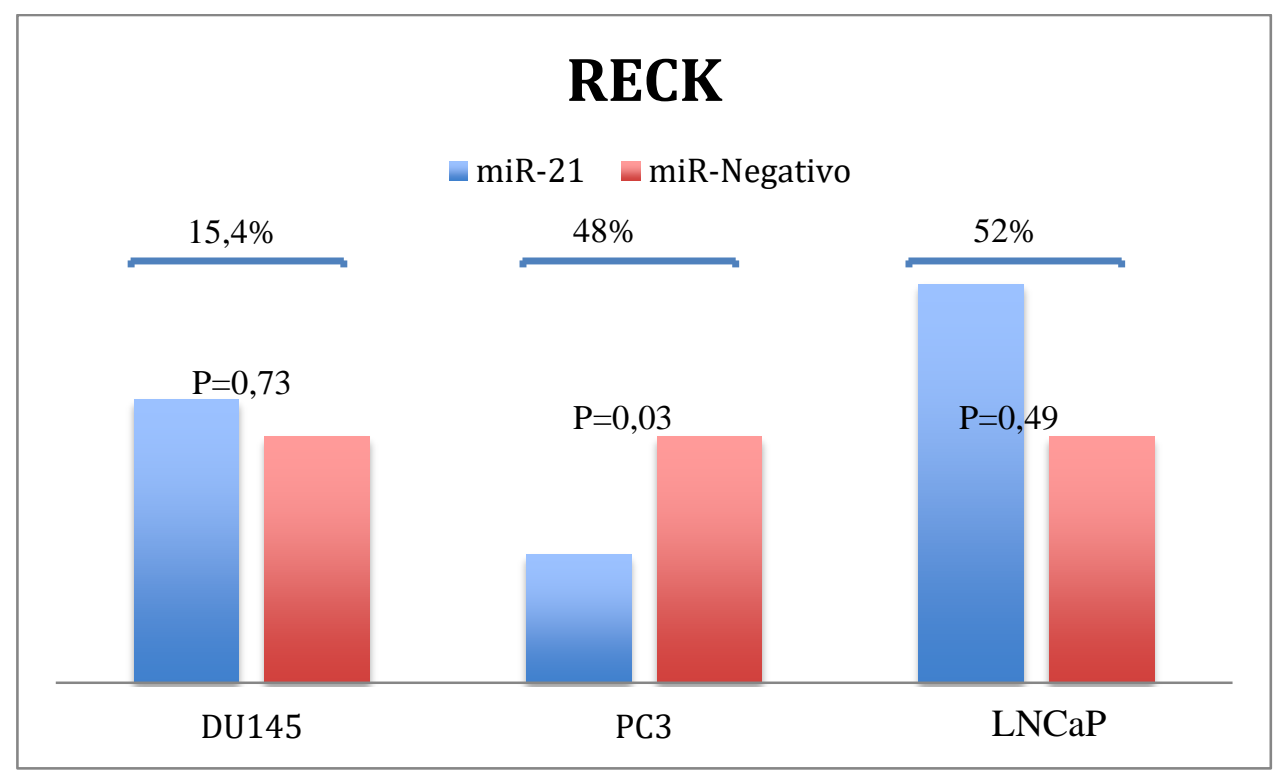

Figura 1 - Expressão de RECK em três linhagens celulares distintas após transfecção do miR-21 comparado com o seu controle 


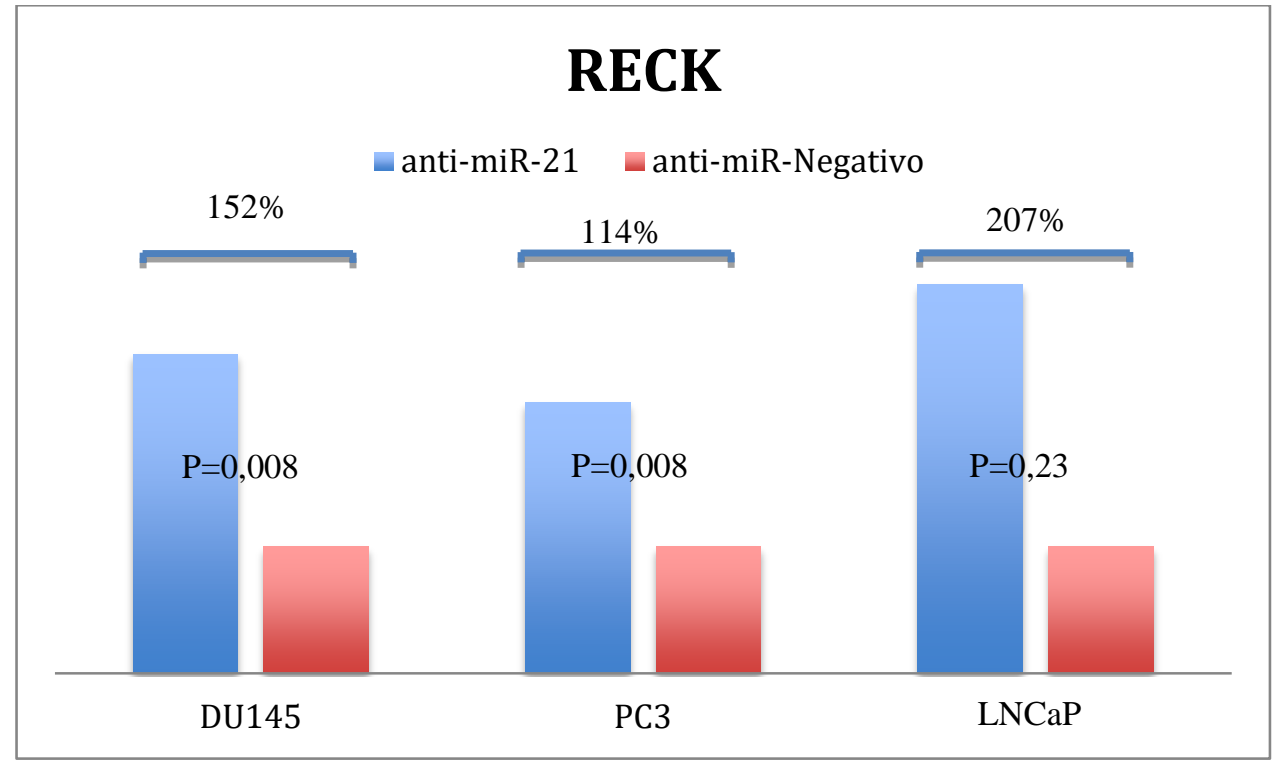

Figura 2 - Expressão de RECK em três linhagens celulares distintas após bloqueio do miR-21 comparado com seu controle.

\subsubsection{MMP-9}

MMP-9 foi considerada um alvo indireto de miR-21 pois este miRNA inibe a proteína RECK que por sua vez liberaria a MMP-9 de sua repressão. Desta forma, avaliamos também a expressão de MMP-9. As células da linhagem PC3 mostraram um aumento estatisticamente significativo na expressão de MMP-9 quando comparadas ao grupo controle $(p=0,025)$. Observando as demais linhagens, constatamos uma maior expressão de MMP9 pelo grupo transfectado com o miR-21 na DU145 $(p=0,31)$, porém reduzida na LNCaP $(p=0,40)$ (Figura 3).

Apesar de esperarmos que houvesse redução da expressão de MMP-9 nas células quando foi realizado o bloqueio do miR-21, foi observado aumento 
da expressão em duas delas (Figura 4).

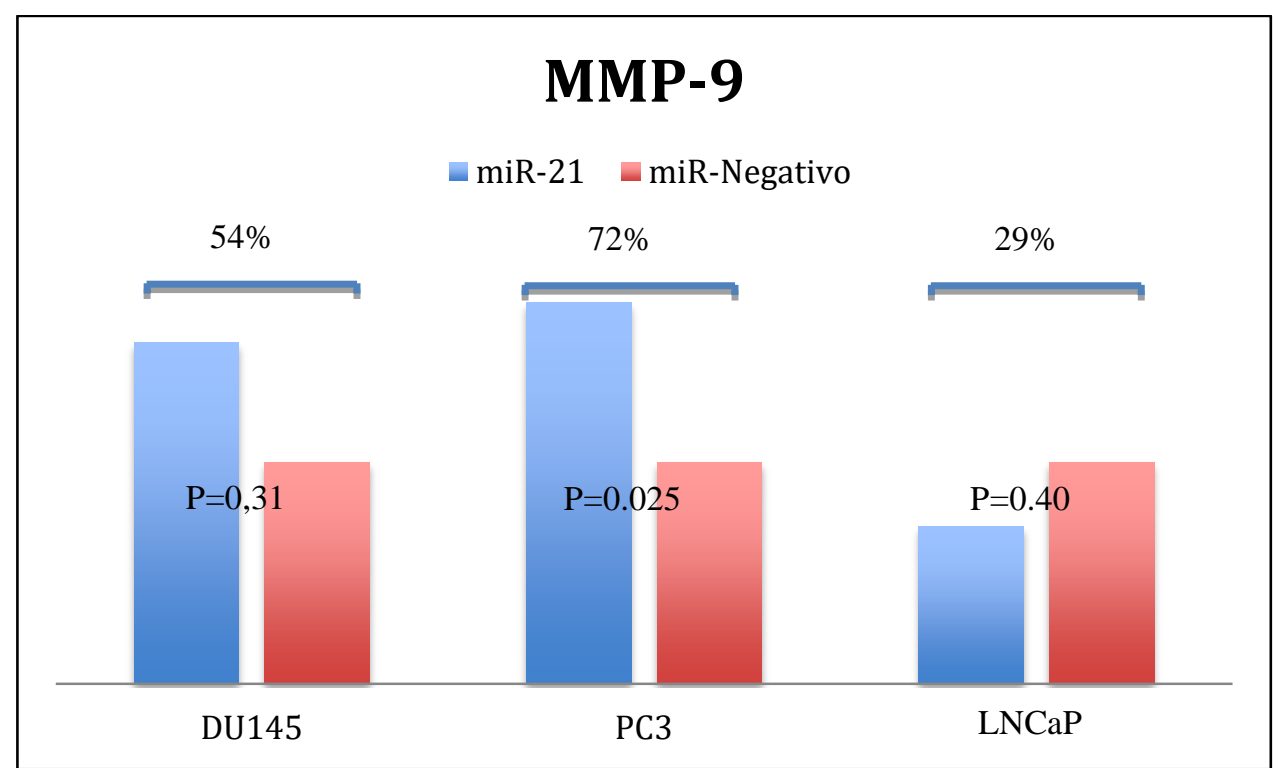

Figura 3 - Expressão de MMP-9 nas linhagens celulares transfectadas com miR-21 e comparadas ao seu controle.

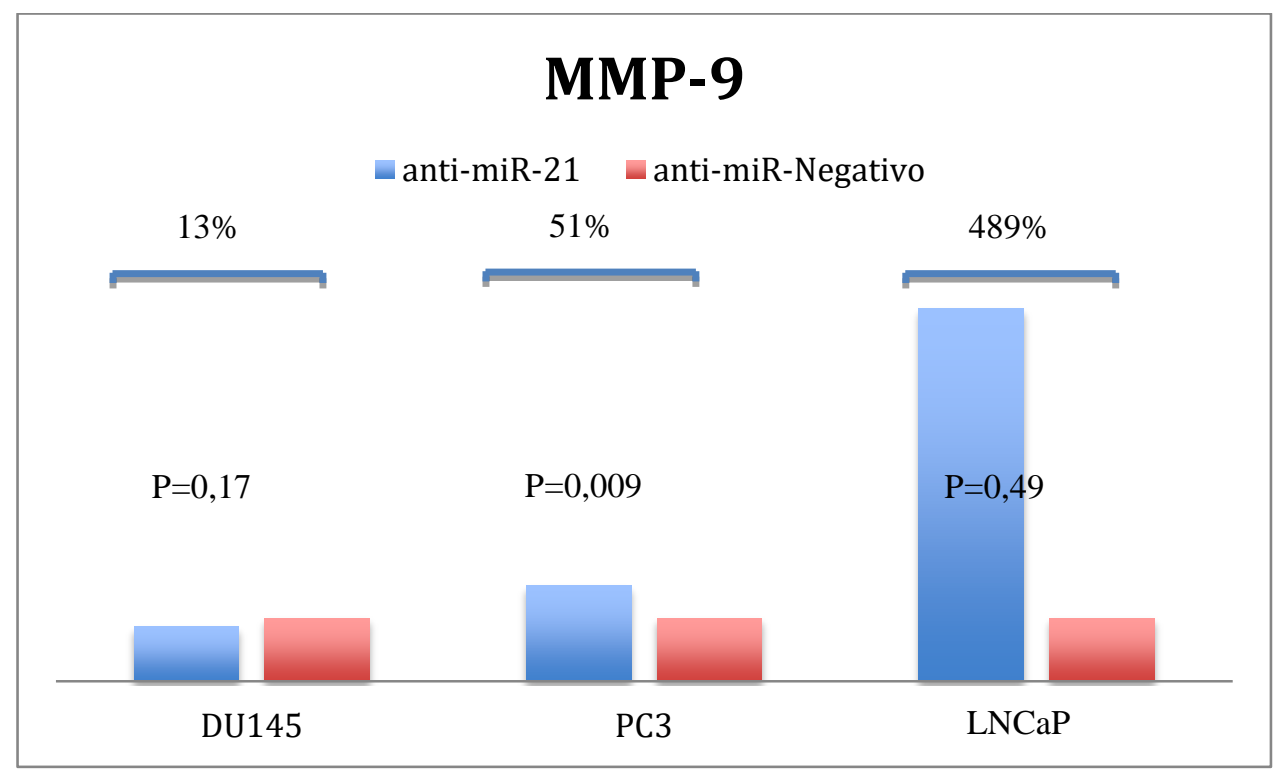

Figura 4 - Expressão de MMP-9 nas células quando foi feito o bloqueio do $\operatorname{miR}-21$. 
4.1.3. Ensaios de Invasão/Migração celular

Nos ensaios de invasão celular não houve diferenças significativas no número médio de células por campo observado que invadiram em ambas as linhagens DU145 e PC3 ( $p=0,102$ e $p=0,092$, respectivamente) entre os grupos miR-21 e anti-miR-21. No entanto, quando contamos o número médio de colônias de células por campo, as linhagens DU145 e PC3 mostraram um maior número de colônias no grupo transfectado com miR-21 (Figura 5 e 6).
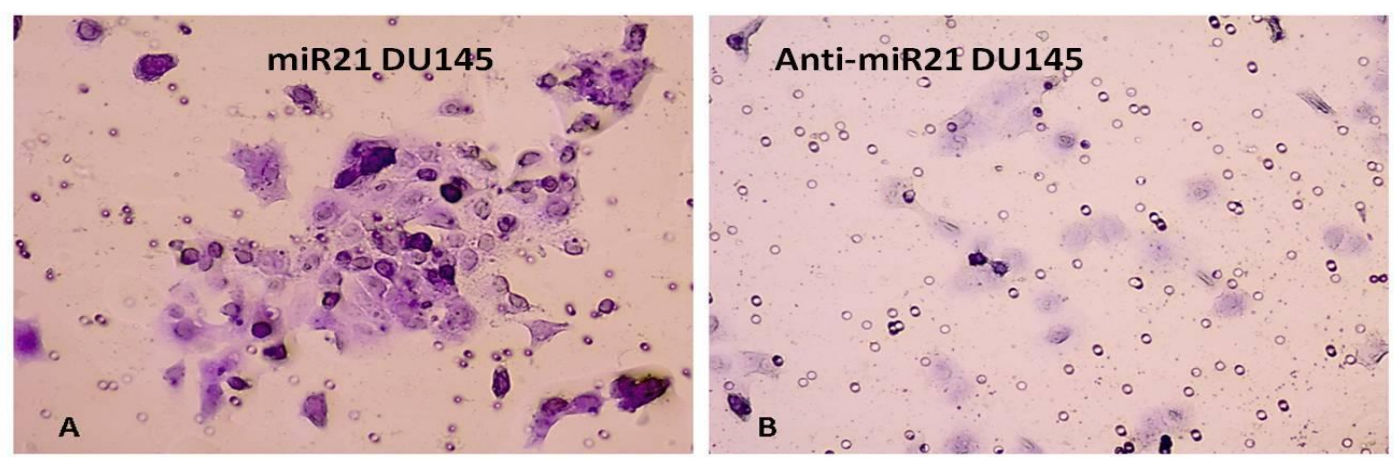

Figura 5 - Foto de microscopia óptica da câmara de Boyden após ensaio de invasão com matrigel com células DU145. As células transfectadas com miR21 apresentam maior potencial invasivo. 


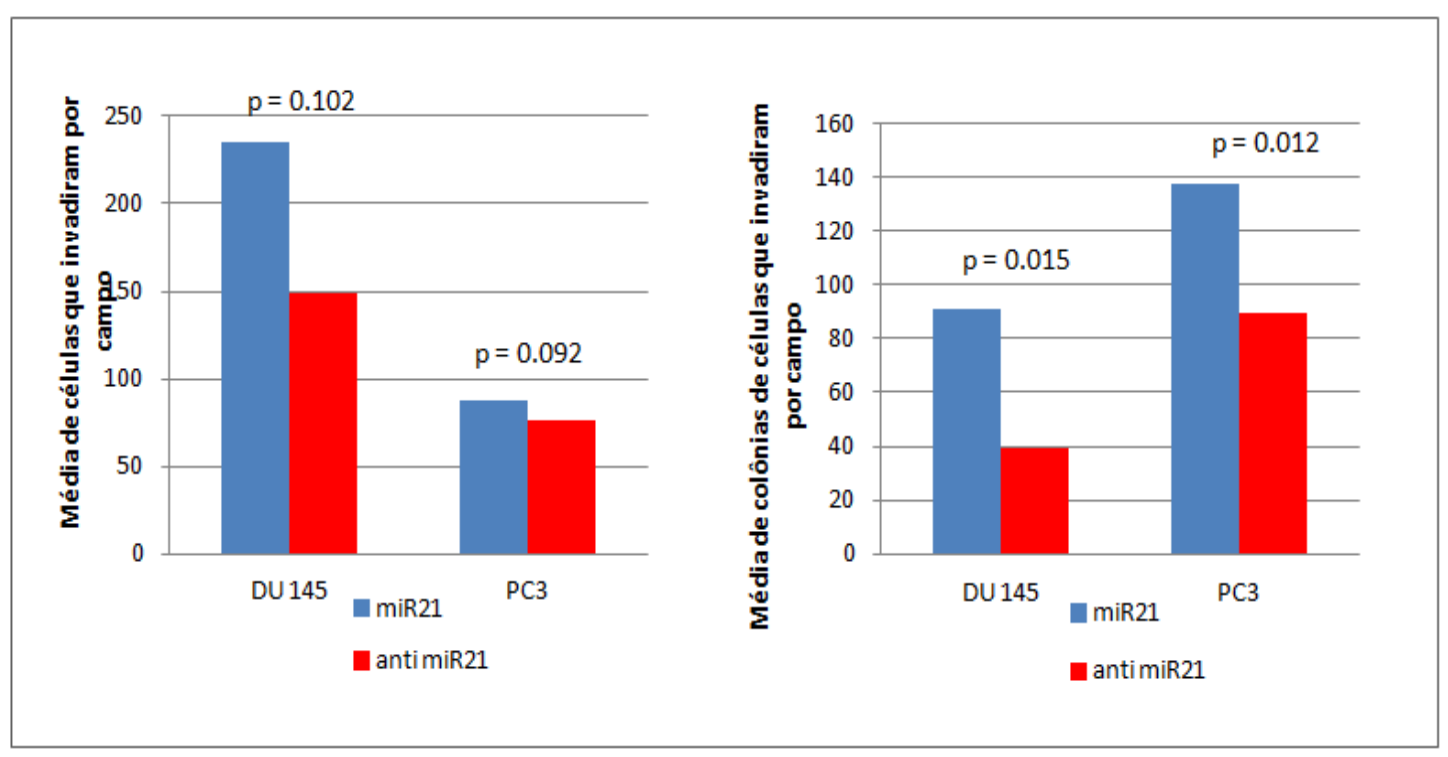

Figura 6 - Número médio de células e colônias de células transfectadas com miR-21 e anti-miR-21 que invadiram a câmara inferior do meio Transwell. Linhagens DU145 e PC3.

\subsubsection{ELISA para MMP-9}

Realizamos o ensaio de ELISA com o meio condicionado das células das linhagens DU145 e PC3 após transfecção com miR-21 ou seu antagonista. Nas células DU145 transfectadas com o miR-21 foram obtidas 0,140 unidades de absorbância de MMP-9 ao passo que as transfectadas com o seu controle negativo tinham 0,063 ; um valor cerca de 2,2 vezes maior $(p=0,101)$. Quando analisamos a concentração de MMP-9 no meio condicionado desta mesma linhagem celular quando haviam sido transfectadas com anti-miR-21 observamos que este valor foi de 0,053 quando comparado àquelas transfectadas com o antagonista negativo (anti-mir negativo); a qual foi de $0,0816(p=0,359)$ (Tabela 1$)$. 
Desta maneira, estes resultados sugerem que o miR-21 pode aumentar a produção de MMP-9 cerca de 2 vezes, ao passo que o anti-miR-21 reduz a confecção desta MMP em quase 35\%.

Tabela 1 - Concentração de MMP-9 obtida com ensaio de ELISA nas células DU145.

\begin{tabular}{|c|c|c|}
\hline $\begin{array}{c}\text { Grupo de Células } \\
\text { Transfectadas }\end{array}$ & $\begin{array}{c}\text { Concentração de MMP-9 } \\
\text { na DU145 }\end{array}$ & p \\
\hline Mir-21 & 0,140 & 0,101 \\
\hline Mir negativo & 0,063 & \\
\hline Anti-mir-21 & 0,053 & \multirow{2}{*}{0,359} \\
\hline Anti-negativo & 0,081 & \\
\hline
\end{tabular}

Realizamos o mesmo procedimento com o meio condicionado de células PC3 transfectadas com o miR-21 (Tabela 2). A concentração de MMP-9 no grupo transfectado com miR-21 e o controle negativo foi 0,128 e 0,094 , respectivamente $(p=0,06)$. Os valores para as células que receberam o antimiR-21 e o antagonista negativo foram, respectivamente; 0,052 e 0,062 $(p=0,217)$. Portanto, os efeitos do miR-21 em aumentar a concentração de MMP-9 e do anti-miR-21 em reduzi-las foram semelhantes também nas células PC3. A razão do aumento foi cerca de 1,32 vezes e da redução de quase $16 \%$. 
Tabela 2 - Concentração de MMP-9 obtida com ensaio de ELISA nas células PC3.

\begin{tabular}{|c|c|c|}
\hline Micro RNA & $\begin{array}{c}\text { Concentração de MMP-9 } \\
\text { na PC3 }\end{array}$ & p \\
\hline Mir-21 & 0,128 & \\
\hline Mir negativo & 0,094 & 0,06 \\
\hline Anti-mir-21 & 0,052 & \\
\hline Anti-negativo & 0,062 & 0,217 \\
\hline & & \\
\hline
\end{tabular}

\subsubsection{Modelo in vivo miR-21}

No modelo in vivo, 4 camundongos NUDE tiveram células da linhagem PC3-M-LUC injetadas no flanco. A primeira injeção de tratamento com antimiR-21 foi feita no D14, a segunda no D18 e a última no D23. As imagens de bioluminescência foram feitas nos dias: D0, D7, D14, D16, D21, D28 e D31, conforme representado na tabela 3. Três camundongos da mesma espécie foram usados como controles, os quais foram tratados com injeções de antimiR-negativo (Tabela 3). 
Tabela 3 - Rotina de execução do experimento de acordo com os dias. Grupo anti-miR-21 em destaque

Anti-miR-21

\begin{tabular}{|c|c|c|c|}
\hline & Anti-miR-21 & miR-338-3p & $\begin{array}{c}\text { miR-338-3p + anti- } \\
\text { miR-21 }\end{array}$ \\
\hline Controles (N) & 3 & 5 & 4 \\
\hline Tratados (N) & 4 & 5 & 4 \\
\hline D0 & $\begin{array}{c}\text { Inoculação e } \\
\text { Imagem }\end{array}$ & Inoculação e Imagem & Inoculação e Imagem \\
\hline D7 & Imagem & Imagem & Imagem \\
\hline D11 & - & $1^{a}$ Dose & - \\
\hline D14 & $1^{a}$ Dose + Imagem & Imagem & $1^{\mathrm{a}}$ Dose + Imagem \\
\hline D15 & & - & \\
\hline D16 & Imagem & $2^{\mathrm{a}}$ Dose + Imagem & Imagem \\
\hline D18 & $2^{a}$ Dose & - & $2^{a}$ Dose \\
\hline D21 & Imagem & Imagem & Imagem \\
\hline D23 & $3^{a}$ Dose & & $3^{a}$ Dose \\
\hline D25 & - & Imagem & \\
\hline D28 & Imagem & & Imagem \\
\hline D30 & - & Imagem + Eutanásia & \\
\hline D31 & $\begin{array}{l}\text { Imagem + } \\
\text { Eutanásia }\end{array}$ & & Imagem + Eutanásia \\
\hline
\end{tabular}

A figura 7 representa a razão de variação de luminescência normalizada pelo valor da emissão de fótons no D14 (previamente à primeira injeção de 
anti-miR-21). No gráfico é possível perceber que até o início do tratamento no D14, a razão de luminescência evoluiu da mesma maneira tanto nos camundongos que seriam tratados com a injeção de anti-miR-21 como nos controles. Porém, a partir do D16, os camundongos tratados com o anti-miR-21 tiveram uma tendência de evolução da luminescência inferior aos animais do grupo controle. Apesar de não observarmos diferença estatisticamente significativa entre os dois grupos, observamos que nos camundongos tratados, a razão de luminescência esteve em geral abaixo dos animais controle (Tabela $4)$.

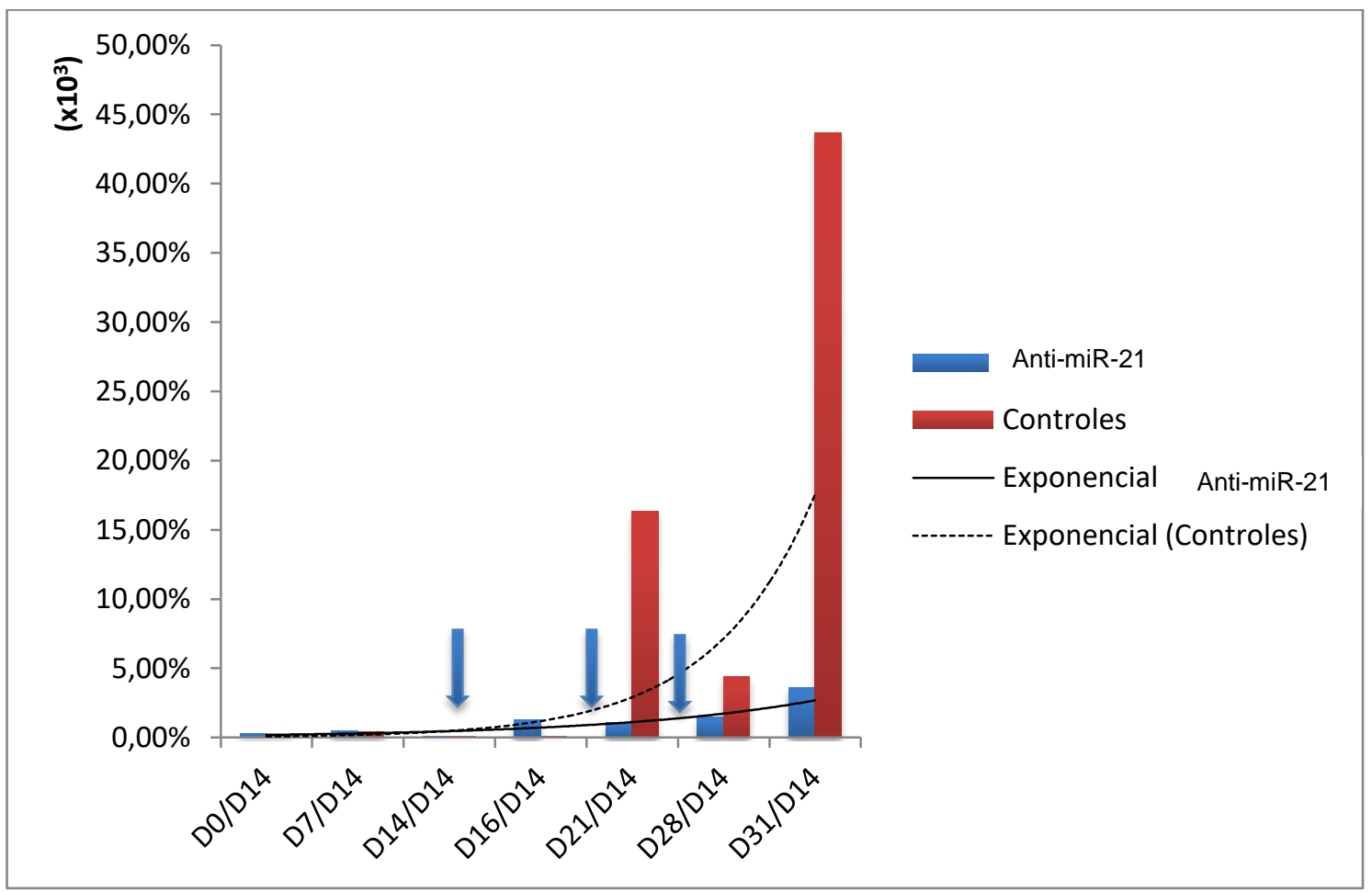

Figura 7 - Evolução da Razão de Crescimento da Luminescência normalizado pelo D14. As setas em azul representam os dias de tratamento com anti-miR21 ou anti-miR-negativo (D14, D18 e D23) 
Tabela 4. Comparação entre razão de aumento de luminescência entre os camundongos tratados com anti-miR-21 e seus controles

\begin{tabular}{|c|c|c|c|}
\hline & anti-mir-21 & Controles & $\mathbf{p}$ \\
\hline $\mathbf{D}$ 0/D14 & $2,86 \mathrm{E}+00$ & $2,48 \mathrm{E}+00$ & 0,90 \\
\hline $\mathbf{D} 7 / \mathbf{D} 14$ & $4,66 \mathrm{E}+00$ & $4,52 \mathrm{E}+00$ & 0,97 \\
\hline $\mathbf{D 1 4} / \mathbf{D} 14$ & $1,00 \mathrm{E}+00$ & $1,00 \mathrm{E}+00$ & - \\
\hline $\mathbf{D} 16 / \mathbf{D} 14$ & $1,29 \mathrm{E}+01$ & $9,39 \mathrm{E}-01$ & 0,37 \\
\hline $\mathbf{D} 21 / \mathbf{D} 14$ & $1,09 \mathrm{E}+01$ & $1,63 \mathrm{E}+02$ & 0,38 \\
\hline D28/D14 & $1,47 \mathrm{E}+01$ & $4,42 \mathrm{E}+01$ & 0,52 \\
\hline D31/D14 & $3,61 \mathrm{E}+01$ & $4,36 \mathrm{E}+02$ & 0,41 \\
\hline
\end{tabular}

O aumento da luminescência no grupo que recebeu o anti-miR-21 ocorreu após o termino das injeções, sendo que após o final do tratamento ambos os grupos começam a ter elevação da medida de luminescência.

Quando foi feita a extração do material genético dos tumores que haviam se desenvolvido em cada um dos animais pudemos observar que 0 aumento da expressão de miR-21 (indicando perda do bloqueio exercido pelo anti-miR-21) era acompanhado também pelo aumento da expressão de MMP-9 (Figura 8). Mesmo assim, a média de expressão normalizada do RNAm de MMP-9 foi cerca de $10 \%$ inferior nos animais tratados com anti-miR-21 do que 
nos animais controles (Figura 9).

De acordo com a figura 8, o primeiro deles $(\mathrm{C} 1 \mathrm{~A} 1)$ apresentou o maior bloqueio do miR-21 e por consequência a menor expressão de MMP-9. Já no último animal (C1A4) observou-se o inverso: ausência de bloqueio do miR-21 e maior expressão de MMP-9. A figura 10 exemplifica como se deu a evolução da luminescência nestes dois animais: no C1A1 (no qual a injeção foi eficaz) houve menor emissão de fótons, ao passo que no C1A4 pode-se observar maiores picos de luminescência.

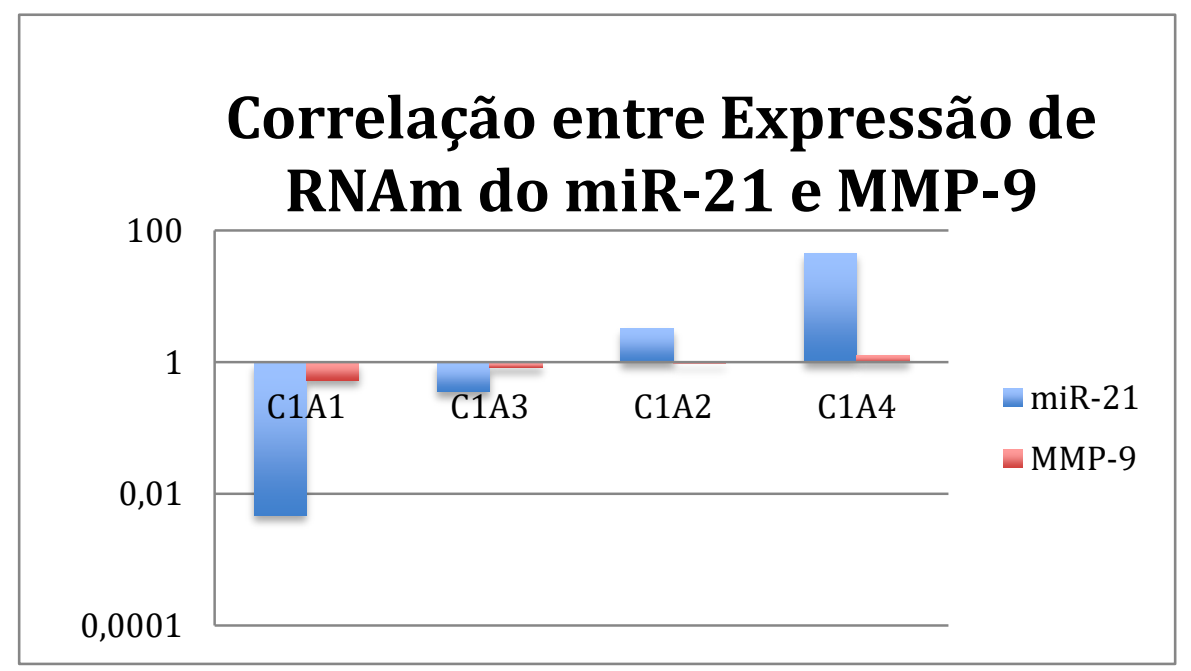

Figura 8 - Aumento da expressão de MMP-9 conforme ocorre perda do bloqueio de miR-21 (C1A1 = camundongo 1; C1A2 = camundongo 2, C1A3 = camundongo 3, C1A4 = camundongo 4). 


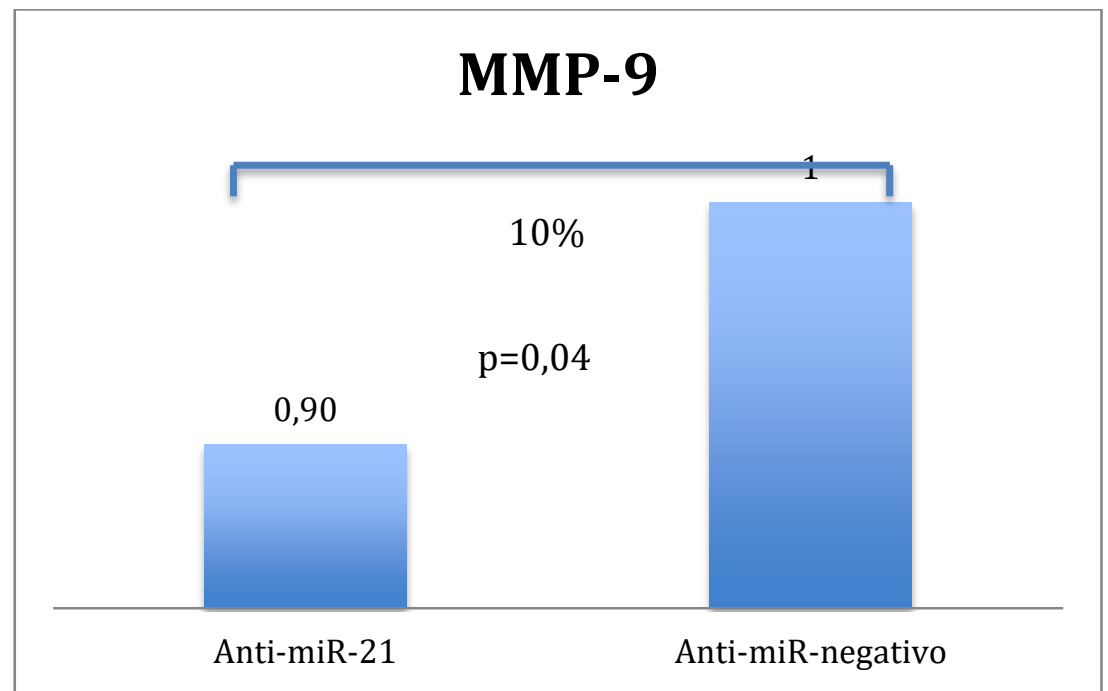

Figura 9 - Expressão de MMP-9 nos tumores extraídos dos camundongos submetidos ao tratamento com anti-miR-21 e comparados aos seus controles. 
C1A1

D14,

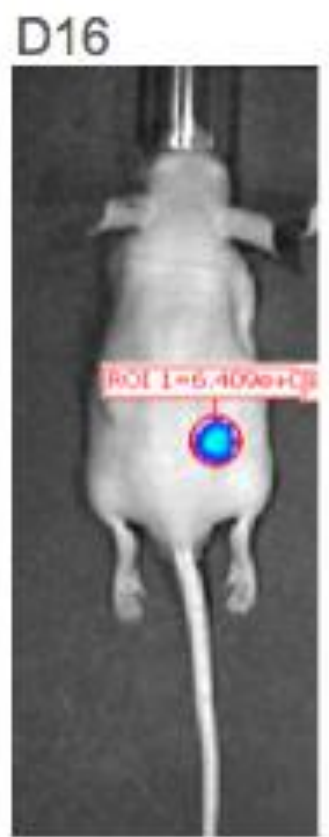

D21

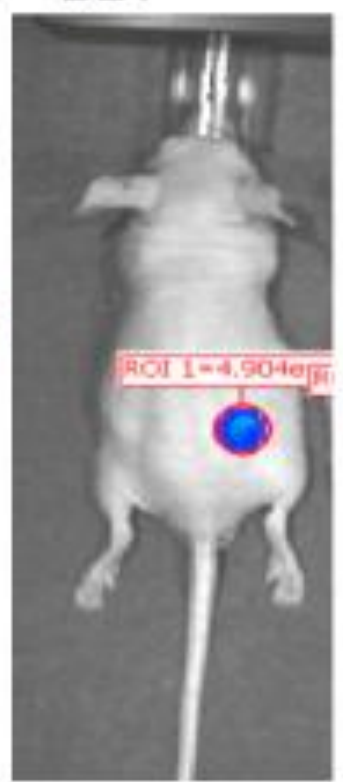

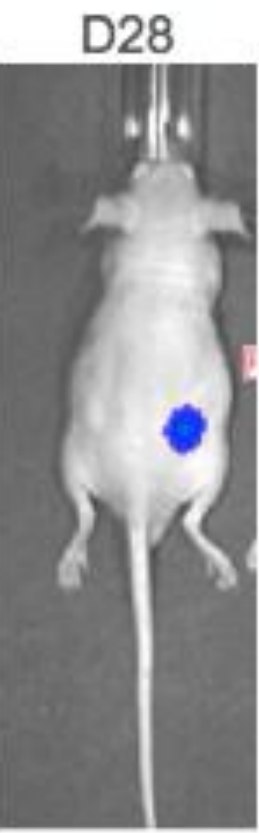

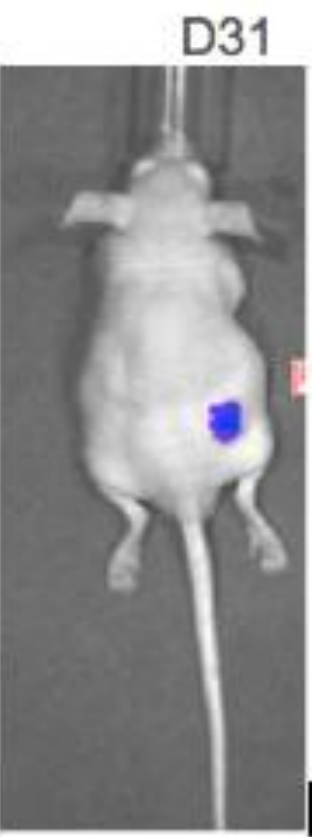

C1A4
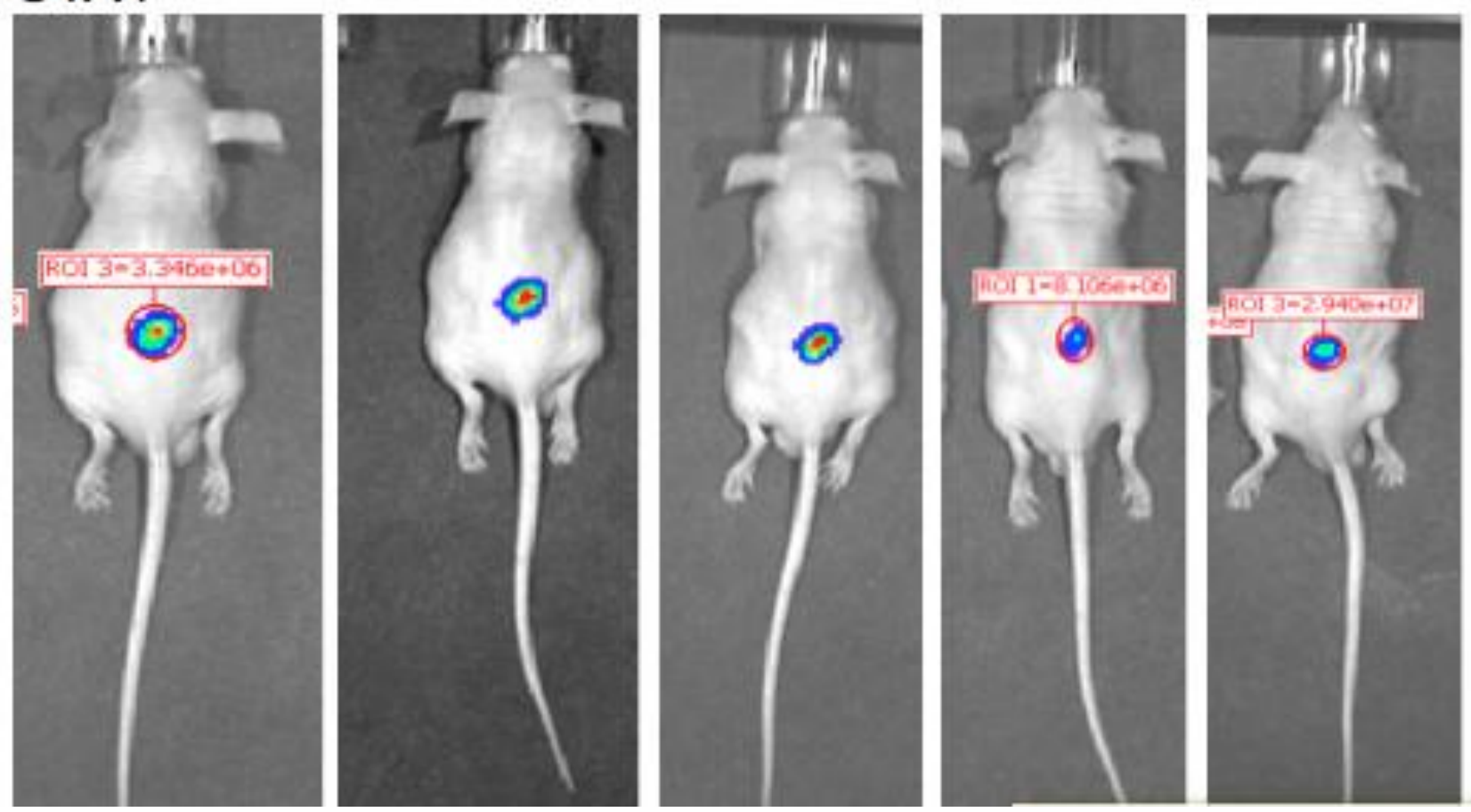

Figura 10 - Evolução da luminescência em dois camundongos tratados: o primeiro (C1A1) houve bloqueio do miR-21 e redução dos níveis de MMP-9 enquanto no segundo (C1A4) não. 


\subsection{Análise da expressão de MMP-9 - miR-338-3p}

\subsubsection{MMP-9}

As células da linhagem PC3 mostraram redução estatisticamente significativa na expressão de MMP-9 após transfecção com o miR-338-3p quando comparadas ao grupo controle $(p=0,001)$. Observando as demais linhagens, DU145 e LNCaP, constatamos que embora houvesse uma menor expressão de MMP-9 pelo grupo transfectado com o miR338-3p, esta não foi estatisticamente significativa $(p=0,16$ e $p=0,23$, respectivamente, Figura 11).

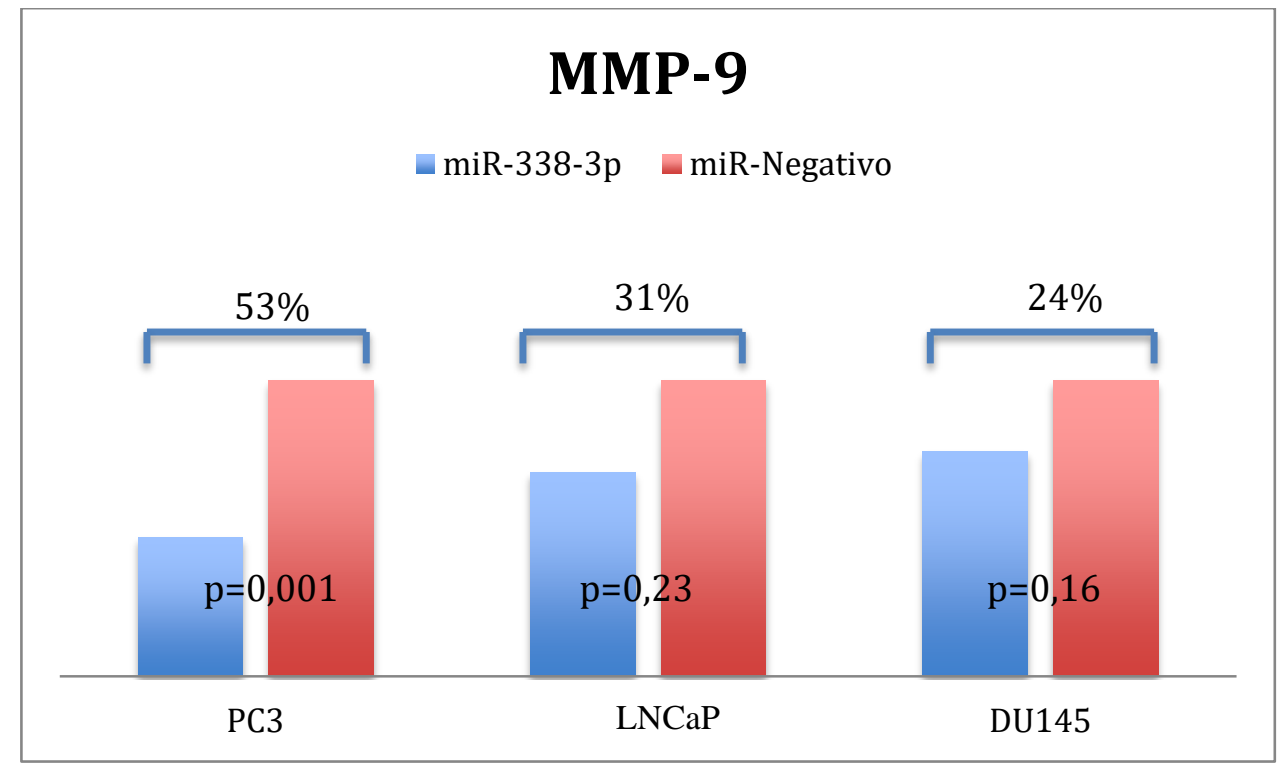

Figura 11 - Expressão de MMP-9 nas células transfectadas com miR-338-3p e seu respectivo controle.

Já quando foi realizado o bloqueio do miR-338-3p pudemos observar um aumento não estatisticamente significativo na expressão de MMP-9, muito embora a expressão nas células da linhagem PC3 tenha sido sobrepujante ao seu controle (Figura 12). 


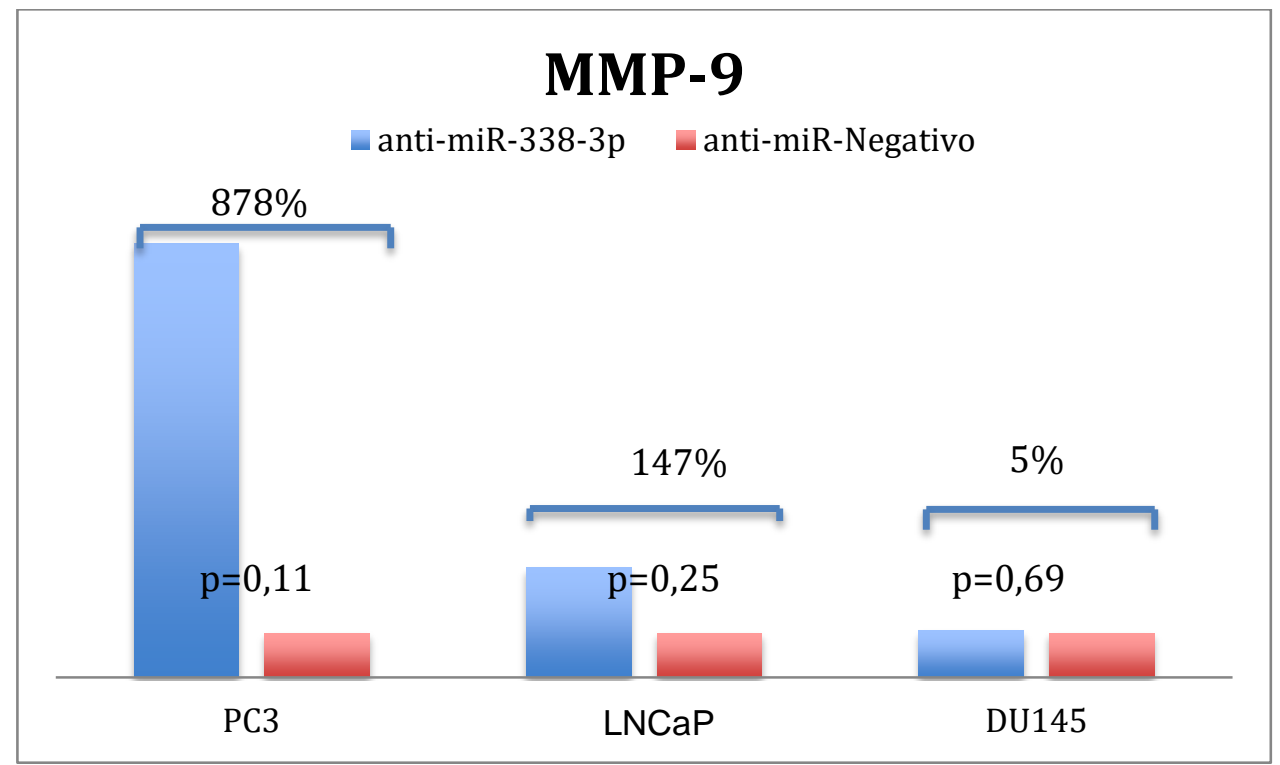

Figura 12 - Análise da expressão de MMP-9, em células transfectadas com anti-miR338-3p, nas linhagens celulares DU145, PC3 e LNCaP.

\subsubsection{Ensaios de Invasão celular}

$\mathrm{Na}$ contagem dos ensaios de invasão celular as células da linhagem DU145 mostraram uma diferença estatisticamente significativa no número médio de células invasoras por campo entre os grupos transfectados com o miR-338-3p e seu respectivo anti-miR $(p=0,002)$. As linhagens PC3 e LNCaP demonstraram também um aumento de MMP-9 nas células transfectadas com anti-miR-338-3p ( $p=0,058$ e $p=0,085$, respectivamente). Quando consideramos a contagem do número médio de colônias que invadiram, as linhagens tiveram um número maior de colônias invasoras nas células transfectadas com antimiR-338-3p, esta diferença foi significativa para linhagem DU145 e a LNCaP $(p=0,042$ e $p=0,007$, respectivamente, Figura 13). Na figura 14, demonstração da invasão das células na linhagem PC3. 


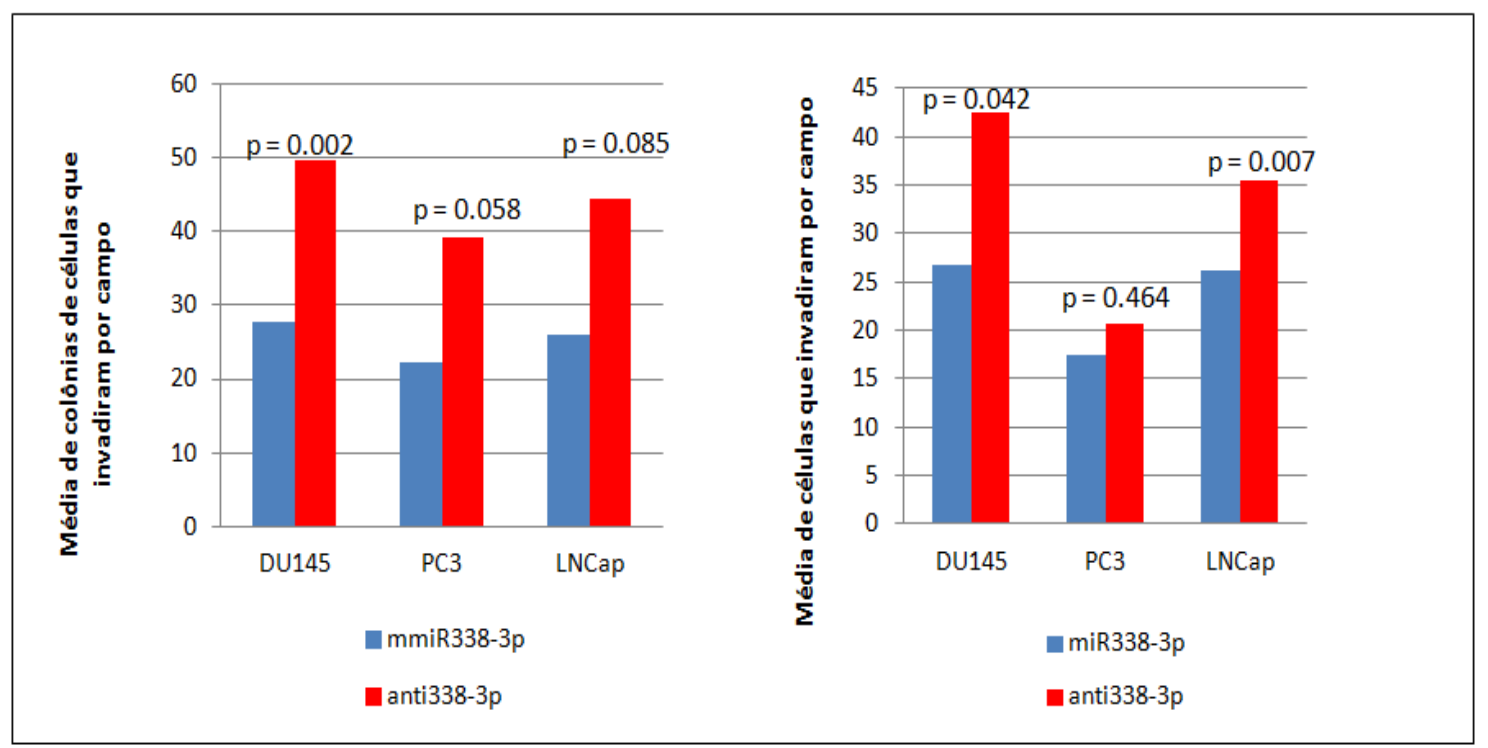

Figura 13 - Número médio de células e colônias de células transfectadas com miR338-3p e anti-miR338-3p que invadiram o matrigel.
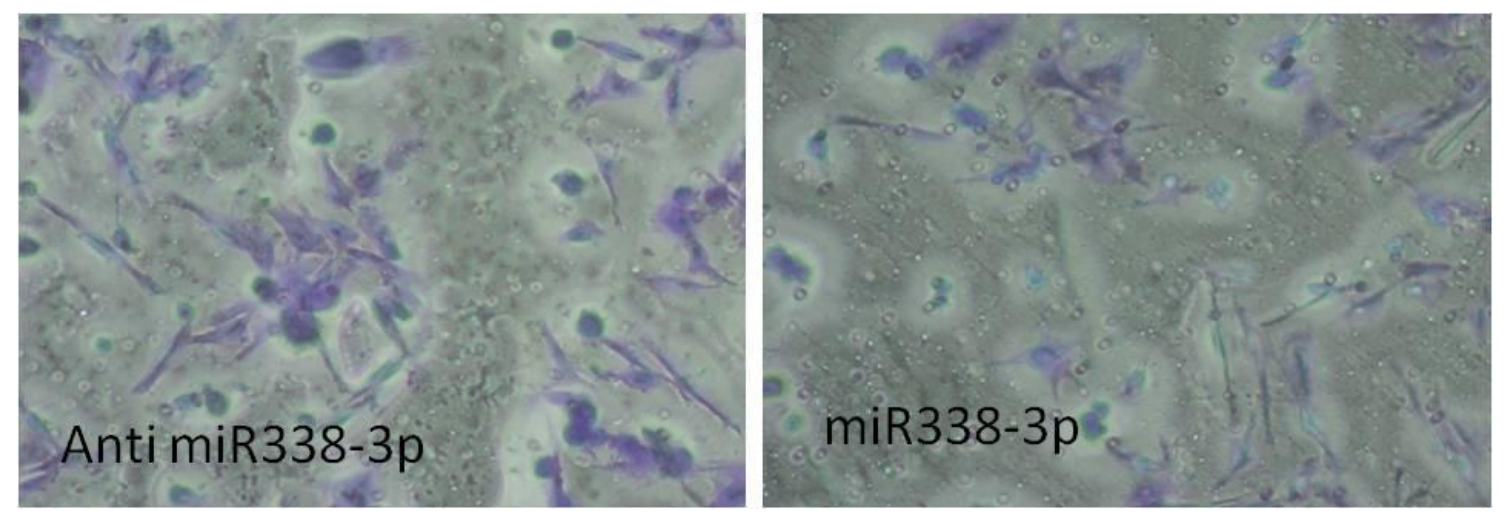

Figura 14 - Fotografia de um dos campos de células da linhagem PC3 transfectadas com miR338-3p e anti-miR338-3p

\subsubsection{ELISA para MMP-9}

Células da linhagem DU145 e PC3 foram transfectadas com miR-338-3p ou seu antagonista, bem como seus respectivos controles negativos. O meio condicionado resultante desta transfecção foi obtido para realização de ELISA para MMP-9. Na DU145 o nível de absorbância para MMP-9 de acordo com o 
microRNA transfectado é mostrado na tabela 5. O miR-338-3p reduz a quantidade de MMP-9 em quase $36 \%$ ao passo que o anti-miR-338-3p eleva esta concentração quase 2,24 vezes (Tabela 5). A absorbância de MMP-9 no meio condicionado das células PC3 quando transfectadas com o mir-338-3p ou seu controle negativo foram de 0,061 e 0,094 ; respectivamente $(p=0,066)$. Os valores para o anti-mir-338-3p e o antagonista negativo foram 0,095 e 0,059; respectivamente. A razão de aumento da metaloproteinase após transfecção com anti-mir-338-3p foi de 1,61x e a redução foi de $35 \%$ com o miR-338-3p. (Tabela 6).

Tabela 5 - Concentração de MMP-9 obtida por ELISA nas células DU145 após transfecção com miR-338-3p, seu antagonista anti-miR-338-3p e seus respectivos controles.

\begin{tabular}{|c|c|c|}
\hline Micro RNA & MMP-9 & p \\
\hline Mir-338-3p & 0,040 & \\
\hline Mir negativo & 0,063 & 0,228 \\
\hline Anti-mir-338-3p & 0,182 & \\
\hline Anti-negativo & 0,081 & 0,259 \\
\hline
\end{tabular}


Tabela 6 - Concentração de MMP-9 obtida por ELISA nas células PC3 após transfecção com miR-338-3p, seu antagonista anti-miR-338-3p e seus respectivos controles.

\begin{tabular}{|c|c|c|}
\hline Micro RNA & MMP-9 & p \\
\hline Mir-338-3p & 0,061 & 0,066 \\
\hline Mir negativo & 0,094 & \\
\hline Anti-mir-338-3p & 0,095 & \multirow{2}{*}{0,098} \\
\hline Anti-negativo & 0,059 & \\
\hline
\end{tabular}

\subsubsection{Modelo in vivo miR-338-3p}

No modelo in vivo, 5 camundongos NUDE tiveram células da linhagem PC3-M-LUC injetadas no flanco. A primeira injeção de tratamento com miR338-3p foi feita no D11, a segunda no D16 e a última no D21. As imagens de bioluminescência foram feitas nos dias: D0, D7, D15, D21, D25 e D30; conforme Tabela 7. Cinco camundongos da mesma espécie foram usados como controles, os quais foram tratados com injeções de miR-negativo. 
Tabela 7- Rotina de execução do experimento de acordo com os dias. Grupo miR-338-3p em destaque.

Anti-miR-21

miR-338-3p

miR-338-3p + anti-

miR-21

\begin{tabular}{|c|c|c|c|}
\hline Controles (N) & 3 & 5 & 4 \\
\hline Tratados (N) & 4 & 5 & 4 \\
\hline D0 & Inoculação e Imagem & $\begin{array}{c}\text { Inoculação e } \\
\text { Imagem }\end{array}$ & Inoculação e Imagem \\
\hline D7 & Imagem & Imagem & Imagem \\
\hline D11 & - & $1^{a}$ Dose & - \\
\hline D14 & $1^{\mathrm{a}}$ Dose + Imagem & & $1^{\mathrm{a}}$ Dose + Imagem \\
\hline D15 & & Imagem & \\
\hline D16 & Imagem & $2^{a}$ Dose & Imagem \\
\hline D18 & $2^{\mathrm{a}}$ Dose + Imagem & - & $2^{a}$ Dose \\
\hline D21 & Imagem & $3^{a}$ dose + Imagem & Imagem \\
\hline D23 & $3^{\mathrm{a}}$ Dose + Imagem & & $3^{a}$ Dose \\
\hline D25 & - & Imagem & \\
\hline D28 & Imagem & & Imagem \\
\hline D30 & - & $\begin{array}{l}\text { Imagem + } \\
\text { Eutanásia }\end{array}$ & \\
\hline D31 & Imagem + Eutanásia & & Imagem + Eutanásia \\
\hline
\end{tabular}

O tratamento com o miR-338-3p ou com miR controle negativo, ocorreu no D11, D16 e D21 do experimento. Quando avaliamos a razão de variação da luminescência entre os dois grupos podemos observar que tanto os controles 
como os animais tratados têm uma tendência de aumento da emissão de fótons. Porém, as linhas de tendência sugerem que os animais tratados têm uma evolução levemente inferior aos controles. Ao término do tratamento no D21, ambas as curvas passam a crescer de forma análoga. Não houve diferença estatística entre os grupos. (Figura 15 e Tabela 8).

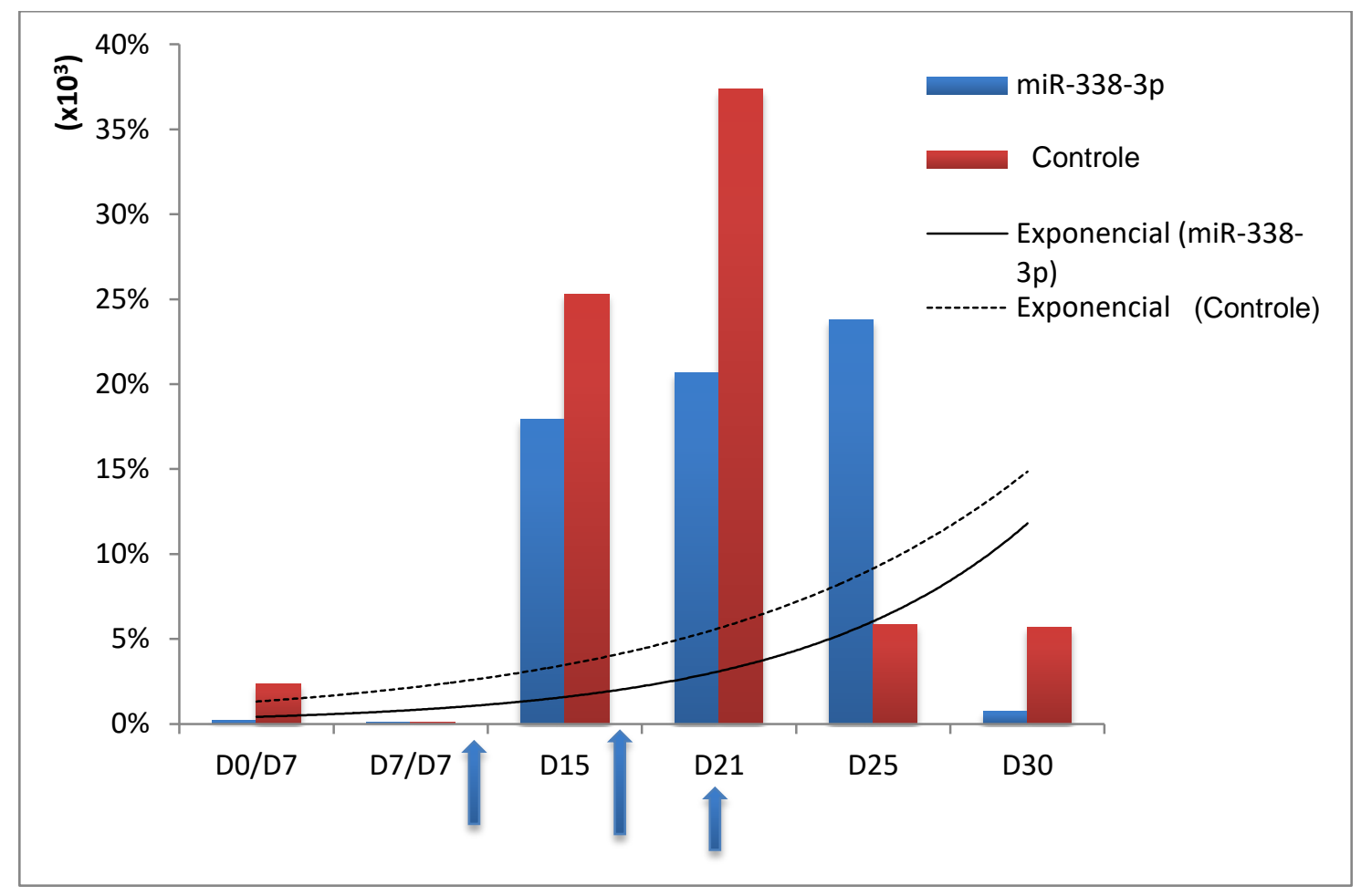

Figura 15 - Evolução da razão de luminescência normalizada pelo D7. As setas em azul representam os dias das injeções de miR-338-3p ou seu controle (D11, D16, D21). 
Tabela 8 - Média da razão de variação de luminescência entre os camundongos tratados com miR-338-3p e os controles.

\begin{tabular}{|c|c|c|c|}
\hline & miR-338-3p & Controle & $\mathbf{p}$ \\
\hline $\mathbf{D 0} / \mathbf{D 7}$ & $1,85 \mathrm{E}+00$ & $2,38 \mathrm{E}+01$ & 0,20 \\
\hline $\mathbf{D 7} / \mathbf{D 7}$ & $1,00 \mathrm{E}+00$ & $1,00 \mathrm{E}+00$ & \\
\hline $\mathbf{D 1 5}$ & $1,79 \mathrm{E}+02$ & $2,53 \mathrm{E}+02$ & 0,74 \\
\hline D21 & $2,07 \mathrm{E}+02$ & $3,74 \mathrm{E}+02$ & 0,60 \\
\hline D25 & $2,38 \mathrm{E}+02$ & $5,85 \mathrm{E}+01$ & 0,49 \\
\hline D30 & $7,28 \mathrm{E}+00$ & $5,70 \mathrm{E}+01$ & 0,25 \\
\hline
\end{tabular}

Após a extração do material genético no ultimo dia do experimento (D30) pudemos observar que o aumento da expressão de miR-338-3p induzido pela injeção do agonista levou à redução da expressão da MMP-9 (Figuras 16 e 17). Enquanto o miR-338-3p foi hiperexpresso em média 5,83x mais em relação aos controles ( $p=0,09$ ), houve redução de cerca de $27 \%$ da expressão do RNAm de MMP-9 $(p=0,07)$; evidenciando que o tratamento foi corretamente realizado. 


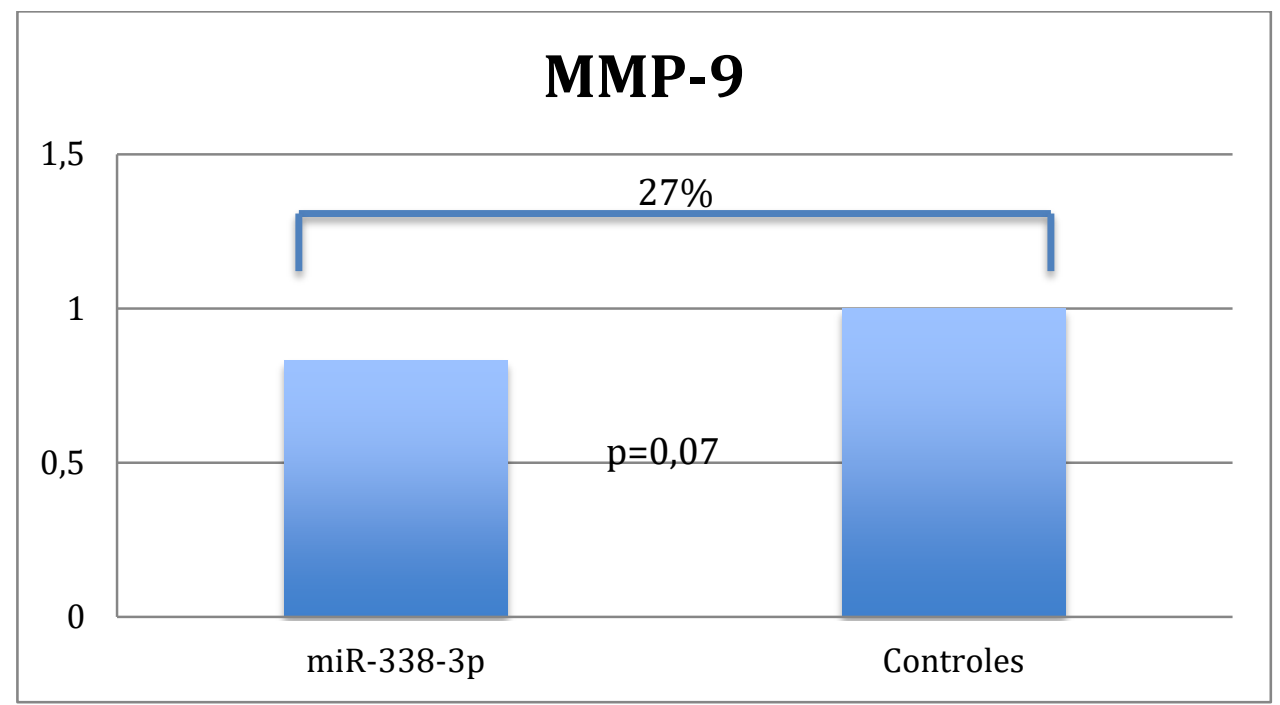

Figura 16 - Expressão de MMP-9 nos tumores extraídos dos animais tratados com injeções de miR-338-3p e comparados com seus controles.

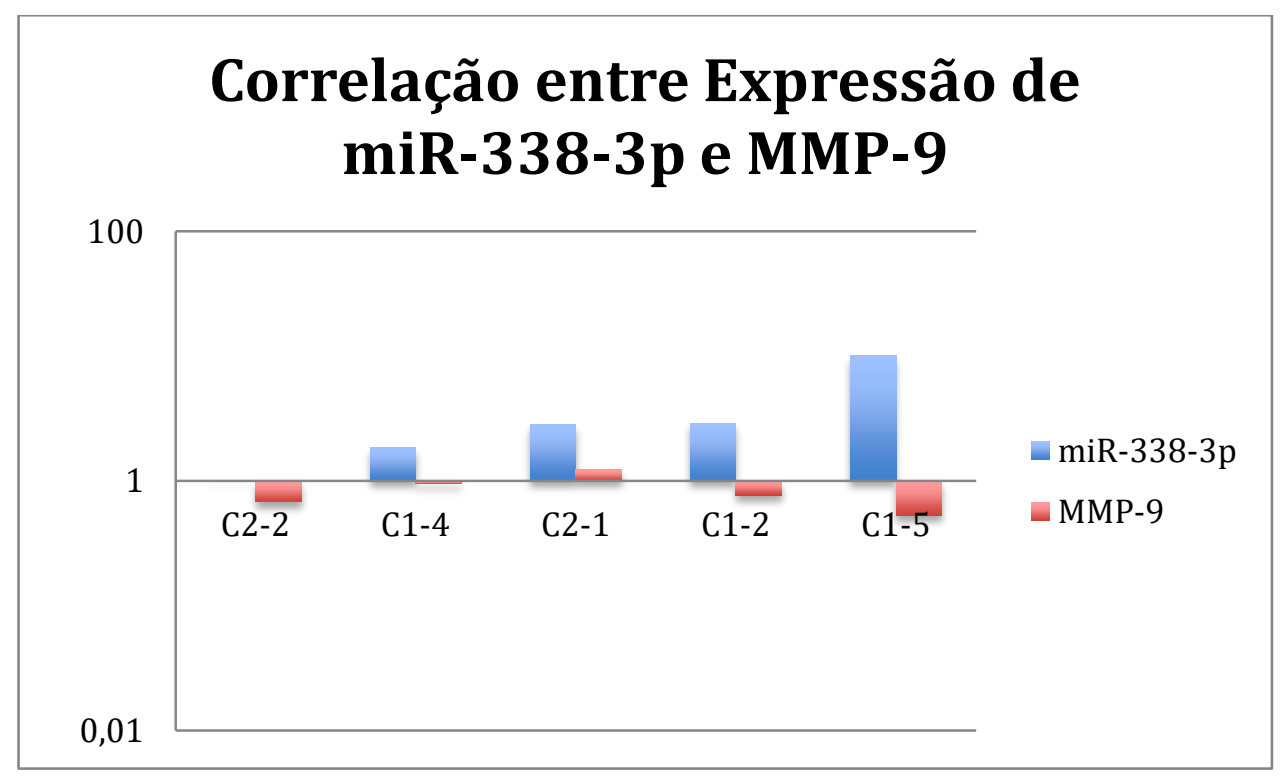

Figura 17 - Relação entre a expressão de MMP-9 e miR-338-3p nos tumores extraídos dos camundongos tratados (C2-2; C1-4; C2-1; C1-2 e C1-5 representam cada um dos camundongos tratados com miR-338-3p). 


\subsection{Ensaio de Co-Transfecção anti-miR-21 e miR-338-3p}

Diante dos resultados obtidos com o miR-21 e miR-338-3p, ambos influenciando a expressão de MMP-9; interrogamos a possibilidade de ambos os microRNAs agirem de maneira sinérgica. Assim sendo, realizamos a transfecção conjunta em 3 grupos diferentes: miR-21+anti-miR-338-3p, os quais aumentam a concentração de MMP-9 conforme mostrado previamente; anti-miR-21+miR-338-3p, que a reduzem e os controles anti-mir-negativo+mirnegativo. Cada grupo foi estudado em triplicata.

4.3.1 Análise da Expressão do RNAm de MMP-9 na co-transfecção

A figura 18 representa o resultado do qRT-PCR para cada um dos grupos descritos. Ele demonstra que o processo empregado obteve êxito. À esquerda, no grupo transfectado com o miR-338-3p+anti-miR-21; vemos que 0 miR-21 foi efetivamente bloqueado com a transfecção do seu antagonista (antimiR-21) e o miR-338-3p foi amplificado. Já no grupo anti-miR-338-3p+miR-21, observamos o oposto: o miR-21 foi efetivamente hiperexpresso e o miR-338-3p bloqueado.

Além disso, comparamos os níveis de expressão do RNAm de MMP-9 após as co-transfecções. É possível observar que a combinação anti-miR$21+$ miR-338-3p reduz de forma significativa a expressão desta MMP (Figura 
19).

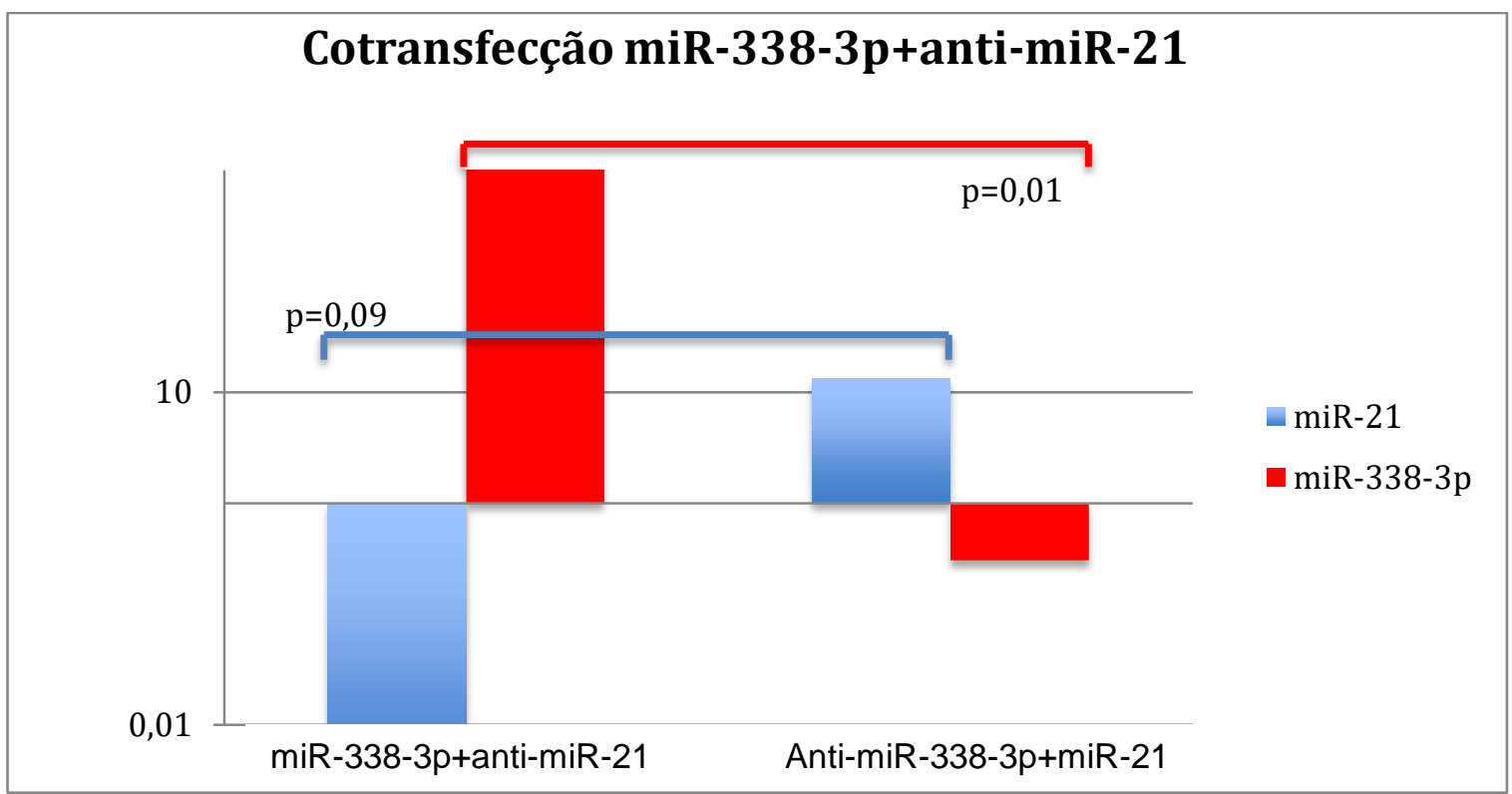

Figura 18 - Resultado de qRT-PCR após extração do miRNA de células DU145 que passaram pela co-transfecção.

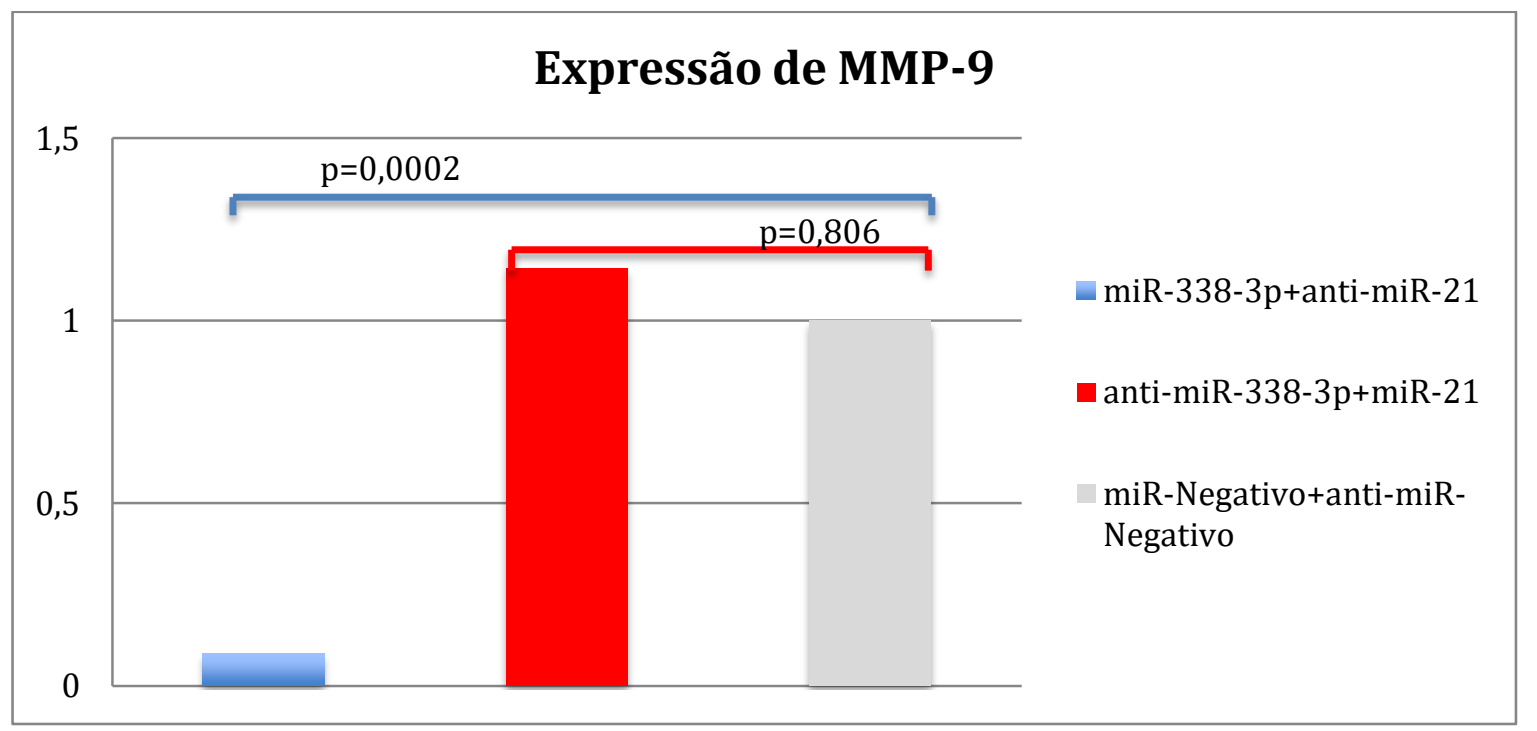

Figura 19 - Expressão de MMP-9 após a co-transfecção do miR-338-3p e antimiR-21.

Já na figura 20, colocamos a representação da expressão de MMP-9 em 
seis situações distintas e observamos que ocorre redução gradual da MMP-9, sendo a maior expressão observada com a transfecção do miR-21 e a menor com a combinação miR-338-3p+anti-miR-21.

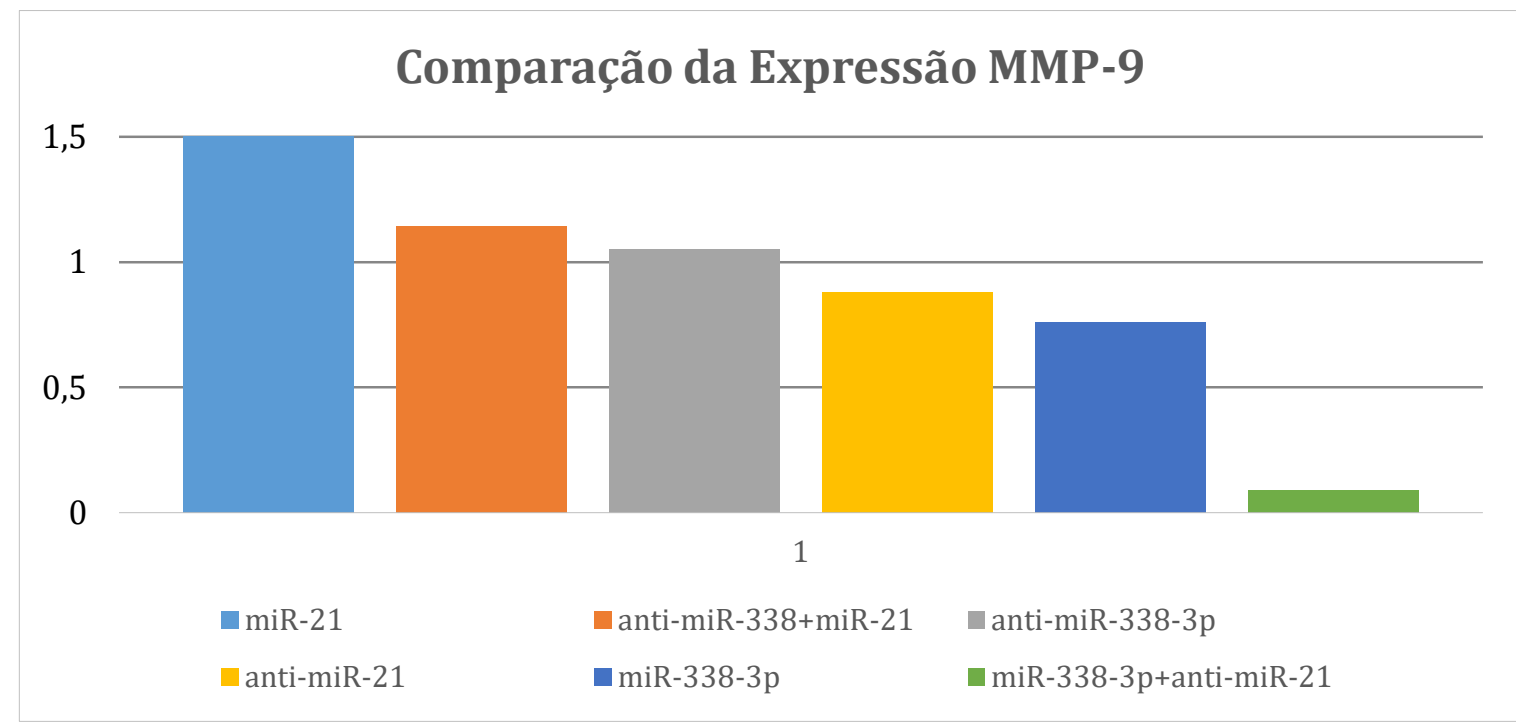

Figura 20 - Comparação da expressão de MMP-9 em diferentes combinações de transfecção de células DU145.

\subsubsection{ELISA para MMP-9 na Co-transfecção.}

Realizamos ensaio de ELISA para determinar a concentração de MMP9 nos dois grupos de interesse. Confirmamos nossa hipótese de que as células transfectadas com o complexo anti-miR-21+miR-338-3p deveriam apresentar menor quantidade da MMP-9. O valor médio de absorbância para este grupo foi de 2,5739 ao passo que para o outro grupo, miR-21+anti-miR-338-3p foi de 21,9648 . Apesar do resultado não ter sido estatisticamente significativo a razão entre eles é de 8,5 vezes (Tabela 9). 
Tabela 9 - Valores de absorbância de MMP-9 detectados por ELISA na co-transfecção

\begin{tabular}{|c|l|c|c|}
\hline & Média & $\begin{array}{c}\text { Desv. } \\
\text { Padrão }\end{array}$ & p \\
\hline $\begin{array}{c}\text { Antimir21 + } \\
\text { mir-338-3p }\end{array}$ & 2,5739 & 1,5631 & $\mathrm{p}=0,275$ \\
\hline $\begin{array}{c}\text { mir-21+ } \\
\text { anti-mir- } \\
\text { miR-338-3p }\end{array}$ & 21,9648 & 27,3279 & \\
\hline
\end{tabular}

\subsubsection{Matrigel na Co-transfecção}

Para o ensaio de matrigel utilizamos $3 \times 10^{4}$ de células da linhagem DU145. Elas foram transfectadas da mesma maneira que foi explicado na sessão acima sobre co-transfecção. Após $48 \mathrm{~h}$ s de transfecção, as células foram ressuspendidas, lavadas e utilizadas para ensaio de invasão pela técnica de matrigel conforme descrito em materiais e métodos.

A tabela 10 mostra que o grupo de células transfectados com miR21+anti-miR-338-3p apresentou maior quantidade de células (média=304 células) e colônias (média=21,33) que invadiram a câmara inferior. Embora sem significância estatística este dado nos mostra que a associação destes dois miRNAs que tem capacidade de aumentar a produção de MMP-9 poderiam provavelmente elevar a capacidade de migração e metástase celular. A figura 21 ilustra estes achados. 
Tabela 10 - Média do número de células e colônias (DU145) que invadiram o matrigel no ensaio de invasão.

\begin{tabular}{|c|c|c|c|}
\hline & Células & Colônias & p \\
\hline miR21+anti338-3p & 304,00 & 21,33 & \multirow{2}{*}{0,275} \\
\hline Anti-miR21+mir338-3p & 114,67 & 7,33 & \\
\hline
\end{tabular}
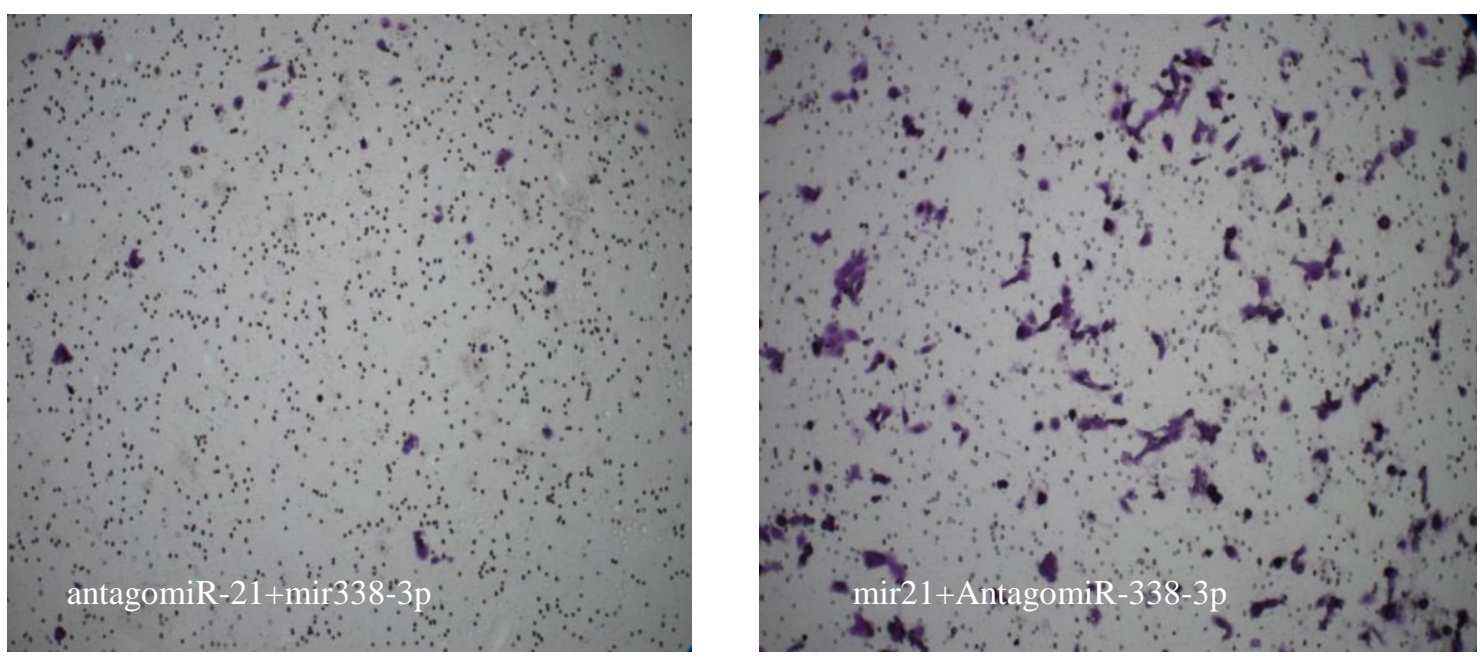

Figura 21 - Ensaio de matrigel nas células DU145 co-transfectadas. Há maior quantidade de células e colônias com a associação miR-21+anti-miR-338-3p

\subsubsection{Modelo in vivo da co-transfecção}

No modelo in vivo, 4 camundongos NUDE machos tiveram células da linhagem PC3-M-LUC injetadas no flanco. A primeira injeção de tratamento com a combinação anti-miR-21+miR-338-3p foi feita no D14, a segunda no D18 e a última no D23. As imagens de bioluminescência foram feitas nos dias: D0, 
D7, D14, D16, D21, D28 e D31 conforme ilustrado na tabela 11. Quatro camundongos da mesma espécie foram usados como controle, os quais foram tratados com injeções da combinação anti-miR-negativo+miR-negativo.

Tabela 11- Rotina de execução do experimento de acordo com os dias. Grupo miR-338-3p + anti-miR-21 em destaque.

Anti-miR-21

miR-338-3p $m i R-338-3 p+a n t i-$ miR-21

\begin{tabular}{|c|c|c|c|}
\hline Controles (N) & 3 & 5 & 4 \\
\hline Tratados (N) & 4 & 5 & 4 \\
\hline D0 & Inoculação e Imagem & Inoculação e Imagem & $\begin{array}{c}\text { Inoculação e } \\
\text { Imagem }\end{array}$ \\
\hline D7 & Imagem & Imagem & Imagem \\
\hline D11 & - & $1^{\mathrm{a}}$ Dose + Imagem & - \\
\hline D14 & $1^{\mathrm{a}}$ Dose + Imagem & Imagem & $1^{a}$ Dose + Imagem \\
\hline D15 & & - & \\
\hline D16 & Imagem & $2^{a}$ Dose + Imagem & Imagem \\
\hline D18 & $2^{a}$ Dose + Imagem & - & $2^{a}$ Dose \\
\hline D21 & Imagem & Imagem & Imagem \\
\hline D23 & $3^{a}$ Dose + Imagem & & $3^{a}$ Dose \\
\hline D25 & - & Imagem & \\
\hline D28 & Imagem & & Imagem \\
\hline D30 & - & Imagem + Eutanásia & \\
\hline D31 & Imagem + Eutanásia & & $\begin{array}{l}\text { Imagem + } \\
\text { Eutanásia }\end{array}$ \\
\hline
\end{tabular}


Avaliando a razão de aumento da luminescência, normalizada pelo D14 (dia da primeira injeção) a curva dos animais tratados com a combinação miR338-3p+anti-miR-21 foi sempre inferior ao dos controles e o aumento observado pela linha de tendência ocorre nos dias finais do experimento ao passo que nos animais controles o aumento da luminescência segue em ascensão já nas fases iniciais do experimento (Figura 22). Apesar disso, não houve diferença estatisticamente significativa em relação aos dois grupos (Tabela 12).

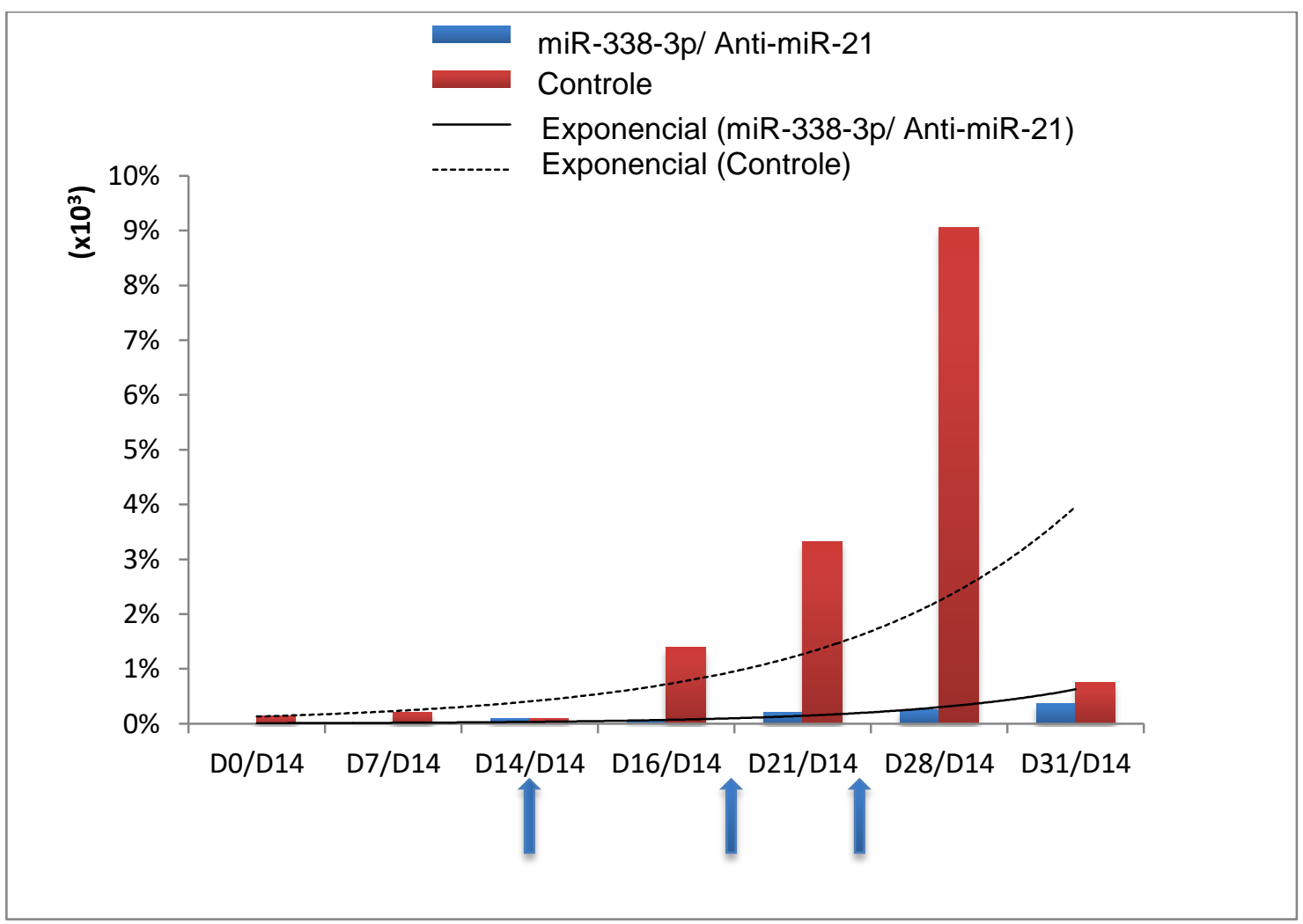

Figura 22 - Razão de aumento da luminescência normalizado pelo D14 - antes da primeira injeção. Setas azuis representam os dias do tratamento (D14, D18, D23). 
Tabela 12 - Média da razão de variação de luminescência entre os camundongos tratados com miR-338-3p+anti-miR-21 e os controles.

\begin{tabular}{|c|c|c|c|}
\hline & $\begin{array}{l}\text { miR-338-3p } \\
\text { anti-miR-21 }\end{array}$ & Controles & $p$ \\
\hline D0/D14 & 2,89E-02 & $1,46 \mathrm{E}+00$ & 0,24 \\
\hline D7/D14 & 1,81E-01 & $2,12 \mathrm{E}+00$ & 0,25 \\
\hline D14/D14 & $1,00 \mathrm{E}+00$ & $1,00 \mathrm{E}+00$ & - \\
\hline D16/D14 & 6,82E-01 & $1,39 \mathrm{E}+01$ & 0,34 \\
\hline D21/D14 & $2,10 \mathrm{E}+00$ & $3,32 \mathrm{E}+01$ & 0,26 \\
\hline D28/D14 & $2,57 \mathrm{E}+00$ & $9,05 E+01$ & 0,37 \\
\hline D31/D14 & $3,73 \mathrm{E}+00$ & $7,58 \mathrm{E}+00$ & 0,30 \\
\hline
\end{tabular}

A extração do material genético dos tumores revelou que provavelmente no dia em que foram sacrificados não havia mais hiperexpressão do miR-3383p e/ou bloqueio do miR-21 (Figura 23). Contudo, o RNAm de MMP-9 estava subexpresso, em todos os camundongos (Figura 23). 


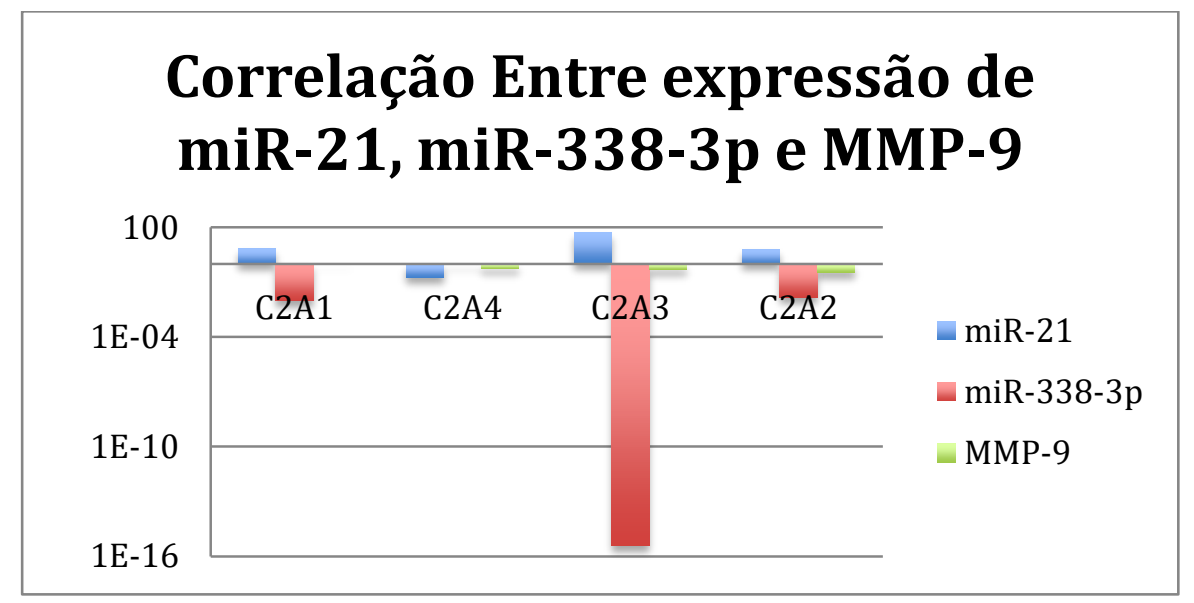

Figura 23 - Demonstração da Expressão de RNAm de MMP-9 em cada um dos camundongos tratados com a combinação miR-338-3p+anti-miR-21

Ao fazermos a analise da dos níveis de expressão de MMP-9 nos animais com a combinação anti-miR-21+miR-338-3p pudemos observar que houve redução de aproximadamente $39 \%$ dos níveis de expressão do RNAm da MMP-9 (Figura 24).

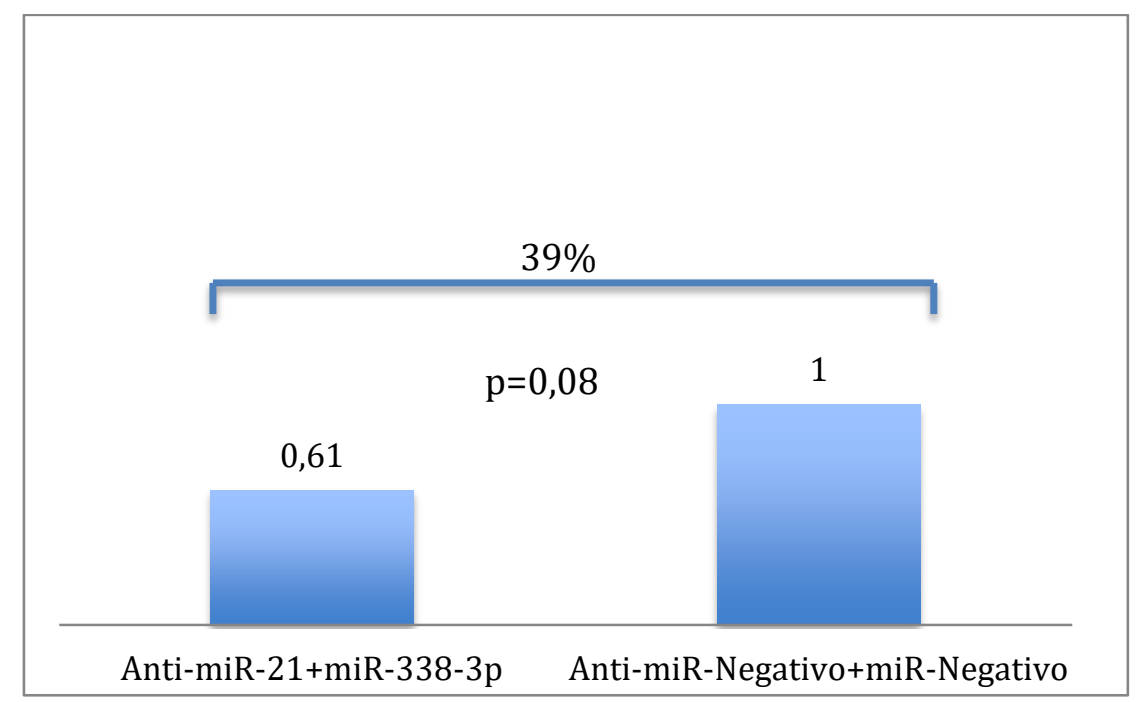

Figura 24 - Expressão relativa de RNAm de MMP-9. Os camundongos tratados com a associação de miRNAs apresentam uma redução próxima à 39\% dos níveis de RNAm de MMP-9. 
5. Discussão 


\subsection{Alteração da Expressão Gênica de RECK e MMP-9 após transfecção do $\mathrm{miR}-21$}

A proteína RECK é uma glicoproteína com cerca de 110kDa ancorada à membrana celular. Sua expressão é normal em tecidos sadios; porém reduzida em tecidos neoplásicos (53). A baixa expressão de RECK em células malignas pode levar ao aumento dos níveis de MMP-9, causando aumento da invasão e metástase celular $(54,55)$. Além disso, a relação inversa entre RECK e MMP-9 foi descrita para neoplasias colorretais (56), colangiocarcinoma (57), glioma (58), estômago (59), sarcomas ósseos (60), pulmão (61) e próstata $(34,48)$. Os resultados deste trabalho se somam aos anteriores de nosso grupo ao mostrarmos que o bloqueio do miR-21 elevou os níveis de RECK em todas as linhagens celulares, sendo estatisticamente significativo em duas delas.

A redução dos níveis de RECK pode ocorrer devido à inibição da região promotora do gene sp1 (62), o qual pode ser inibido pelo miR-21. Trabalhos conduzidos no LIM-55 mostraram que o miR-21 pode reduzir os níveis de RECK tanto em linhagens celulares como em espécimes cirúrgicos de prostatectomia radical onde observamos que ocorre redução de RECK em pacientes com maior expressão de miR-21. Contudo, pelo menos no CaP ainda não foi avaliada se tal inibição ocorre também por influência do fator promotor sp1, o qual também pode ser alvo deste miRNA de acordo com ferramentas preditoras (www.microrna.org).

Algumas publicações sugerem os mecanismos através dos quais o miR21 encontra-se hiperexpresso na neoplasia de próstata. Ribas et al viram que a 
região promotora deste miRNA pode ser regulada positivamente pelo receptor de andrógeno e que além disso, em espécimes cirúrgicos de $\mathrm{CaP}$ de baixo risco o miR-21 estava aumentado em cerca de $3 x$; sugerindo que a hiperexpressão deste miRNA é um evento precoce na patogênese desta neoplasia. Contudo, o miR-21 não apenas pode atuar no desenvolvimento do $\mathrm{CaP}$ nas fases iniciais, quando as células são andrógeno-dependentes; porém podem ainda levar a progressão do tumor para formas andrógenoindependentes. Ou seja, este miRNA pode ser importante em dois momentos distintos da evolução da neoplasia (63). Tal achado pode ser corroborado pelo fato de que pacientes com neoplasias resistentes à castração apresentam níveis séricos mais elevados de miR-21 quando comparados aos pacientes com CaP localizado (64).

A RECK pode inibir a MMP-9 de dois modos, supressão da sua secreção e direta inibição de sua atividade enzimática. Durante o processo de transformação celular, a expressão do gene RECK é inibida, liberando a MMP9 e assim contribuindo para o comportamento invasivo de células cancerosas. Acredita-se que a inibição não seja exclusivamente dependente do nível de expressão de RECK, mas também dos níveis de glicosilação de sítios específicos da proteína (65). Outro mecanismo possível que levaria redução de RECK seria a hiperexpressão da glicoproteína Her-2/neu, podendo assim, aumentar e expressão de MMP-9 (66). Há evidências de que este receptor pode ser hiperexpresso como consequência da privação de andrógenos (67), sendo que níveis elevados de Her-2/neu estão associados ao maior estadiamento patológico, bem como desenvolvimento de doença metastática 
(68), sugerindo uma papel importante da perda de inibição de RECK (que leva a maior atividade de MMP-9) no contexto deste último mecanismo proposto.

Estes dados demonstram que o controle da expressão de RECK é muito complexo e que a ação do miR-21 sobre esta proteína representa mais um mecanismo possível deste controle. Neste estudo observamos que ao se aumentar a expressão de miR-21 com a transfecção do seu agonista houve redução da expressão de RECK apenas na linhagem PC3 ao passo que LNCaP e DU145 praticamente mantiveram-se iguais. Contudo, houve aumento da expressão de MMP-9 na DU145 e PC3, um resultado importante quando consideramos que houve também um maior número de células invasoras no ensaio de matrigel e um maior de nível de absorbância de MMP-9 no ensaio de ELISA para as células transfectadas com miR-21.

Já o bloqueio do miR-21 com o seu antagonista elevou os níveis de RNAm de RECK em todas as linhagens celulares, não sendo significativo apenas na LNCaP. Contudo, não foi observado redução da expressão de RNAm de MMP-9, podendo ser explicado pelo fato de que a inibição da MMP-9 pela RECK ocorre ao nível proteico e não ao nível do RNAm. Mas, uma vez que os níveis de RNAm de RECK são elevados com o bloqueio do miR-21, a atividade enzimática da proteína MMP-9 pode ser reduzida. Neste aspecto, nossos resultados estão congruentes nos quais a transfecção do antagonista do miR-21 reduziu a capacidade invasiva das células. A avaliação com ensaio de zimografia para testar a atividade de MMP-9 associado ao Western-blot ou ELISA para RECK poderia ter nos ajudado a confirmar tal hipótese (se bloqueio do miR-21 restaura os níveis de RECK sem modificar os níveis de RNAm de 
MMP-9; mas reduzindo a atividade desta última no nível proteico).

Um dos primeiros estudos envolvendo miRNA para tratamento de xenoenxertos de células de neoplasias de próstata foi conduzido por Mercatelli et al (69). Neste estudo foram injetadas $1.5 \times 10^{6}$ células PC3 nativas no flanco de camundongos e o tratamento com a combinação miR-221/222 foi feita com a dose de $1 \mathrm{mcg} /$ injeção, as quais foram realizadas no D0, D5 e D9 do experimento. Neste estudo as células tratadas com a combinação de miRNA apresentavam velocidade de crescimento inferior aos animais controles. Assim, mesmo que outros miRNA tenham sido usados para o tratamento, estes autores mostraram que os tumores injetados no subcutâneo continuam crescendo ao longo do tempo. A medida do tamanho dos tumores foi feita com paquímetro e a análise sobre a eficácia do tratamento foi feita analisando-se a variação de tamanho do tumor no último dia do experimento com o dia da primeira injeção.

Em nosso experimento, utilizamos camundongos Balb-c nude, nos quais foram injetadas células da linhagem PC3-Luc e realizamos o tratamento com o anti-miR-21. Pudemos notar que a luminescência dos animais nos quais realizamos a injeção do antagonista do miR-21 apresentaram evolução inferior à dos camundongos do grupo controle e estabilidade durante todo 0 tratamento. $\mathrm{O}$ aumento da luminescência no grupo que recebeu o anti-miR-21 ocorreu após o término das injeções, sendo que após o final do tratamento, ambos os grupos começam a ter elevação da medida de luminescência. Dado que a emissão de fótons pelas células é um evento dependente de ATP e, portanto, pode ser feita apenas por células viáveis; é possível que a inibição da 
expressão do miR-21 tenha levado a redução da população de células tumorais nos camundongos. De fato, o miR-21 está implicado na regulação do ciclo celular e apoptose; além de mecanismos de metástase $(70,71)$.

O experimento in vivo demonstrou que o aumento da expressão de miR21 (indicando perda do bloqueio exercido pelo anti-miR-21) era acompanhado também pelo aumento da expressão de MMP-9, algo que no final levou a redução de aproximadamente $10 \%$ na média de expressão normalizada do RNAm de MMP-9 nos animais tratados com anti-miR-21.

O fato de não termos obtido uma redução maior na expressão de MMP9 (no modelo in vivo) na vigência do bloqueio do miR-21 sugere que expressão de RECK e MMP-9 esteja sendo regulada por outras vias e que o bloqueio do miR-21 não tenha sido suficiente para suplantá-las. Há evidências de que a expressão de MMP-9 pode ser controlada pelas vias da MAPK, PI3K/Akt, ERK1/2 e c-Jun. Pesquisadores estudando o efeito da alfa-solanina mostraram que o bloqueio da via ERK ou PI3K/Akt reduzem a expressão de MMP-9, bem como levam ao aumento da expressão de RECK em células da linhagem PC3 (72)

A Fosfatidil-inositol 3-quinase (PI3K) é uma proteína heterodimérica composta de uma subunidade catalítica $(\mathrm{p} 110 \mathrm{a} / \mathrm{b} / \mathrm{g} / \mathrm{d})$ e outra reguladora (p85alfa/beta) que é ativada por citocinas e fatores de crescimento. Após esta ativação a PI3K é direcionada para a membrana celular onde realiza a conversão de fosfatidil-inositol bi-fosfato (PIP2) para fosfatidil-inositol tri-fosfato (PIP3). Este último serve de apoio para a ligação da proteína Akt, a qual sofre duas fosforilações nas posições Treonina308/309 e Serina 473/474 pelas 
quinases PDK-1 e PDK-2; respectivamente. Shukla et al demonstrou que esta via está ativada em células das linhagens PC3 e LNCaP, porém não na

DU145. Tal diferença se deve ao fato de que nas duas primeiras pode não haver atividade do gene PTEN, algo que não ocorre na última. O gene PTEN evita ativação da via PI3K. Além disso, foi demonstrado que a inibição da via PI3K nas células da linhagem PC3 levou a redução da expressão de MMP-9 e invasão (73). Nas fases iniciais do experimento in vivo, testamos a expressão do gene PTEN nos tumores extraídos do subcutâneo dos camundongos. Não houve amplificação do PTEN em nenhum deles. Assim, conforme exposto acima, a via PI3K poderia estar ativada, levando a uma grande expressão de MMP-9 de tal modo que mesmo com a inibição do miR-21 não foi possível reduzir a expressão desta metaloproteinase. Pode ser que a inibição do miR-21 in vivo seja uma via alternativa para se reduzir os níveis de MMP-9.

\subsection{Análise da alteração de expressão do gene e proteína alvo de miR338-} $3 p$

A sequência precursora do miR-338-3p está codificada dentro de um íntron do gene da AATK (Apoptosis-associated Tyrosine Quinase) no cromossomo 17q25.3. Estudos que utilizaram espécimes cirúrgicos e os compararam à tecidos sem evidência de câncer mostraram que o miR-338-3p encontra-se subexpresso em tumores de reto (74), hepatocarcinoma (75), câncer de esôfago (76), câncer oral (77), neoplasias gástricas (78), colorretais (79), câncer de pulmão não pequenas células (80) e em urologia; no carcinoma 
renal de células claras (81).

Diferentemente do que ocorre no miR-21, que se comporta como um oncomir, o miR-338-3p atua como um supressor tumoral a partir da ação em alguns genes alvo já descobertos. Zhang et al demonstraram em linhagens celulares de carcinoma renal que o miR-338-3p regula negativamente o gene ALK5 e com isso reduzindo motilidade e invasão in vitro; além de existir uma hiperexpressão deste gene associado à hipoexpressão do miR-338-3p em pacientes com carcinoma de células renais do tipo células claras metastáticos em comparação aos casos sem metástase. O gene ALK5 trata-se de um receptor da TGFB-1 dependente de quinase e que realiza a conexão entre a membrana plasmática ao esqueleto de actina, podendo atuar na motilidade e invasão (81). Ainda no carcinoma de células claras, outro estudo demonstrou que o miR 338-3p regula negativamente o gene KIFC1, o qual atua no ciclo celular, realizando a ancoragem aos microtúbulos e está associado à maior proliferação celular, migração e metástase bem como hiperexpressão de MMP2 e MMP-9 (82). No CaP outros pesquisadores demonstraram por imunohistoquímica que o gene KIFC1 hiperexpresso está associado a neoplasias com estadiamento patológico mais avançado, escores de Gleason elevados, invasão linfática, vascular e de vesículas seminais. Além disso, o gene KIFC1 pode induzir resistência ao docetaxel (83).

Estudos anteriores mostraram que o potencial metastático em células de linhagem celular de câncer hepático se correlaciona inversamente a expressão de miR-338-3p e positivamente com a expressão da proteína SMO (um receptor acoplado à proteína $\mathrm{G}$ e que quando ativada inicia a cascata 
Hedgehog de transcrição de genes alvo). Foi ainda demonstrado que o gene SMO é diretamente inibido pelo miR-338-3p e como consequência desta ação os níveis de MMP-9 são reduzidos, levando à menor invasão e migração celular (50). Resultado semelhante foi obtido por Sun et al ao demonstrarem que o miR-338-3p atua de modo importante inibindo a proteína SMO da cascata Hedgehog também no carcinoma colorretal, sem contudo ser avaliada migração, invasão ou qualquer expressão de metaloproteinases (84).

Portanto, a regulação de MMP-9 pode ser indiretamente exercida pelo miR-338-3p via cascata Hedgehog conforme proposto por Huang et al no câncer de fígado (50). Em condições fisiológicas, a via Hedgehog está inibida e se torna ativada com a ligação de moléculas (Sonic, Indian ou Desert) ao receptor transmembrana denominada PATCHED $(\mathrm{PTCH} 1)$, o qual então ativa a proteína transmembrana SMO para iniciar transcrição de diversos genes responsáveis pela proliferação, diferenciação e angiogênese (85). No CaP, há trabalhos que evidenciam que componentes desta cascata estão ativados em espécimes cirúrgicos (86). Em linhagens celulares PC3, LNCaP e DU145, a via Hedgehog está ativada e pode ser inibida pela substância ciclopamina (87). Além disso, a via Hedgehog quando ativada aumenta a proliferação celular (88), bem como aumenta a invasividade de linhagens celulares em experimentos in vitro (89).

Estando esta cascata ativada e sendo responsável por aumentar a invasividade de células de $\mathrm{CaP}$ (87) (88), seria plausível avaliar como se comportariam as metaloproteinases no contexto de ativação da via Hedgehog. Em gliomas humanos, por exemplo; Wang et al demonstraram que o bloqueio 
de componentes desta via (Sonic/GLI1) reduzem a expressão de MMP-9 e como consequência a capacidade de invasão celular (90). Resultados semelhantes no que se refere à expressão de MMP-9 ser diretamente relacionada à atividade de elementos da cascata também foram identificados em câncer de mama (91) e pâncreas (92).

O gene IRS2 foi identificado no câncer de pulmão não pequenas células como um alvo do miR-338-3p. Tal gene promove aumento da proliferação celular, apoptose, migração e invasão ativando a via PIK3/Ak3 após recrutamento efetuado pela ativação do IGF-1R (93). No CaP, polimorfismos do gene IRS2 já foram associados à casos com pior prognóstico (94). Outro gene que também atua na cascata PI3K/Akt e que é controlado pelo miR-338-3p é o gene PREX2A, o qual foi mostrado que em neuroblastomas promove a proliferação e invasão celular. O gene PREX2A reduz a atividade de fosfatase do gene PTEN, levando ao acúmulo de PIP3. Como consequência ocorre aumento da fosforilação da treonina-308 AKT e serina-473 AKT; promovendo sobrevivência celular, progressão do ciclo celular e crescimento. Entretanto, também não foi avaliado a relação destas alterações moleculares com a expressão de metaloproteinases (95).

Até mesmo a via metabólica pode ser afetada pelo miR-338-3p. Estudo in vitro com células de câncer de ovário demonstrou que a redução dos níveis de miR-338-3p (evento que ocorre em diversas neoplasias) promove o aumento da expressão da enzima PKM2, que por sua vez está envolvida na via glicólise aeróbia de células neoplásicas (96). E mesmo em estudos com espécimes cirúrgicos de CaP foi relatado maior atividade da enzima PKM2 em 
casos com escore de Gleason mais avançados (Gleason 8-10), sugerindo papel desta enzima na progressão tumoral (97).

Adicionalmente, outro gene; ADAM17 foi comprovado ser regulado diretamente pelo miR-338-3p, entretanto tal conhecimento foi obtido com estudos in vitro em células de câncer gástrico (98). Ocorre que o mesmo gene ADAM17 foi implicado no controle da invasão de células de CaP in vitro através de uma outra via de sinalização (EGFR-MEK-ERK) que por final promove hiperexpressão de MMP-2 e MMP-9 (99). Outra situação que pode promover a hiperexpressão de MMP-9 em células da linhagem PC3 é um ambiente celular em vigência de hipóxia, dado que nesta situação pode ocorrer aumento da expressão do HIF-1a (hypoxia induced factor 1a), levando ao bloqueio da função da E-caderina e com isso aumento da expressão de MMP-9 (100).

A menção aos genes acima, os quais foram relatados como sendo alvos do miR-338-3p - mesmo que em outras neoplasias - tem por objetivo demonstrar que diversos processos da fisiologia celular e bem como vias de sinalização podem ser afetados pela regulação deste miRNA. No CaP inclusive ocorre redução dos níveis de miR-338-3p. Bakkar et al demonstraram que ocorre queda progressiva da expressão deste miRNA conforme ocorre progressão entre epitélio prostático benigno e neoplasia metastática (101).

É possível que o mecanismo inicial que leve à redução dos níveis de miR-338-3p esteja relacionado à hipermetilação nas ilhas $\mathrm{CpG}$ da região promotora do gene que codifica este microRNA, conforme demonstraram Li et al no câncer gástrico (78). Além disso, eles identificaram que o miR-338-3p suprime em nível pós-transcripcional o gene SSX2IP, o qual pode aumentar a 
migração e invasão de células neoplásicas através da ativação de Rac1 (78). Contudo, este último estudo não avaliou a relação destes genes com a expressão de MMPs.

Em relação à neoplasia de próstata, não há na literatura estudos que tenham avaliado a função do miR-338-3p na regulação da MMP-9. Neste trabalho, demonstramos o papel de supressor tumoral deste miRNA ao reduzir a expressão de MMP-9 nos ensaios de qRT-PCR e ELISA e, por consequência; ao reduzir potencial invasivo conforme demonstrado nos experimentos de matrigel. Não podemos afirmar que a MMP-9 é um alvo do miR-338-3p, até mesmo porque ferramentas preditoras de pareamento entre RNAm-miRNA não sugerem que esta associação possa ocorrer. Contudo, a partir de estudos citados anteriormente, o miR-338-3p pode exercer influência sobre os mecanismos de metástases dependente de MMP-9 através de vias de sinalização diversas.

Já no experimento in vivo, também obervamos que os camundongos tratados com a injeção de miR-3383p apresentaram menor expressão de MMP9 e além disso, aqueles que tiveram os menores níveis de MMP-9 eram aqueles que tiveram maiores expressões do miR-338-3p, podendo até mesmo sugerir um limiar necessário da quantidade de miRNA para se promover redução ou aumento da quantidade do RNAm de MMP-9. Ainda no experimento in vivo, observamos que a evolução da emissão de fótons foi inferior nos camundongos tratados com o miR-338-3p quando comparados àqueles que receberam o tratamento com o miRNA negativo. Isso pode ser explicado pelo fato de que apenas células biologicamente ativas emitem sinais 
luminosos e, tendo o miR-338-3p já ter sido também associado à regulação do ciclo celular e apoptose; é possível que nestes animais a injeção possa ter exercido efeito negativo nestes pontos do ciclo celular. De fato, um ensaio que avaliasse apoptose (p. Ex. TUNEL) nos daria pistas neste sentido, apesar deste não ter sido escopo do trabalho.

\subsection{Ensaio de Co-Transfecção anti-miR-21 e miR-338-3p}

A idéia de sinergismo entre miRNAS permitiu que diversos pesquisadores elaborassem modelos teóricos para prever quais associações de miRNAs podem ser responsáveis pelo controle de genes comuns. Estes modelos basicamente utilizam informações disponíveis como os escores de silenciamento ou presença de sítios de interação entre gene-miRNA altamente conservados entre espécies para elaborar mapas de sinergismo entre miRNAs com genes alvo em comum (102). Independentemente disso, estes são modelos matemáticos e teóricos e que necessitam de validação experimental.

A associação de miRNAs tem se mostrado capaz de ampliar o controle sobre mRNA alvo. Estudando a ação sinérgica entre miRNAs em condrócitos de um modelo de osteoartrite, foi demonstrado que a associação de ambos foi capaz de elevar a expressão do RNAm de TIMP-1 e colágeno tipo II (103). Outros autores contudo, avaliando a co-transfecção do miR-375 com miR-206 em células de carcinoma espinocelular de laringe não identificaram ser a associação mais eficaz em reduzir a proliferação celular, invasão e apoptose quando comparadas à transfecção isolada do miR-375 (104). Outros autores 
identificaram que a combinação do miR-424 com miR-381 é superior para controle de proliferação e controle de apoptose em células de câncer de rim (105). Contudo, a avaliação de sinergismo entre miRNAs no controle de MMP-9 no câncer de próstata ainda não foi relatada. Nossos experimentos conduzidos com o anti-miR-21 e miR-338-3p mostraram que isoladamente ambos podem reduzir a expressão de MMP-9. Entretanto, a co-transfecção promove maior redução da expressão deste gene tanto in vitro como in vivo, sugerindo que na via final estes miRNAs podem ter papel relevante quando usados em conjunto.

Nos experimentos com miR-21 ou mR-338-3p atuando isoladamente pudemos observar no modelo in vivo que a expressão de MMP-9 era tanto menor conforme ocorria hiperexpressão de miR-338-3p ou hipoexpressão de miR-21. Contudo, essa relação não pôde ser replicada quando realizamos 0 tratamento em conjunto com os miRNA. Apesar de existirem estudos que avaliaram sinergismo entre miRNAs, não identificamos algum que tenha empregado modelos in vivo. In vitro, os estudos citados previamente utilizaram outros métodos para transfecção como plasmídeos (103) ou lentivírus (104) ao passo que a base de nossas transfecções in vitro eram realiadas com lipofectamina. In vivo, utilizamos o método divulgado por Minakuchi et al baseado no uso de atelocolágeno (106). Desta maneira, julgamos que nossa proposta foi pioneira em avaliar o sinergismo entre miRNAS em modelos de xenoenxerto de CaP. Outro ponto a ser considerado em experimentos com a combinação de miRNAS é que a concentração de cada miRNA utilizada na mistura pode influenciar a ação sinérgica ou antagônica da co-transfecção conforme publicação de Park et al na qual foi realizada co-transfecção do anti- 
miR-21 e/ou anti-miR-221 em células de câncer de pâncreas (107). Em nosso estudo, utilizamos quantidades equivalentes do anti-miR-21 ou miR-338-3p tanto nos experimentos in vivo como in vitro. Resultados mais complexos talvez poderiam ter sido obtidos caso tivéssemos utilizados diferentes concentrações de miRNA.

Em um trabalho publicado por Dong et al foi realizado transfecção com lipofectamina de miRNAs inibidores (anti-miR-10b e anti-miR-21) para avaliar a resposta de células humanas de glioma quanto à proliferação e invasão. $O$ racional do trabalho foi análogo ao que empregamos em nosso estudo atual: promover a redução da quantidade de miR-21, o qual é sabidamente um oncomiR e que está hiperexpresso na maioria das neoplasias. Os resultados obtidos demonstraram que o sinergismo na inibição conjunta do miR-10b e miR-21 promoveu menor proliferação, invasão e expressão de MMP-2. Foi o único estudo que identificamos em oncologia que avaliou expressão de metaloproteinases e invasão com a cotransfecção (108).

Em resumo, a interação decorrente da transfecção conjunta do miR-338$3 p$ com o anti-miR-21 demonstrou resultados finais que promoveram a redução da expressão da MMP-9 e com isso houve menor invasão das células de câncer de próstata. O sinergismo entre ambas as moléculas pode resultar não da ação direta sobre a MMP-9, mas sim através de genes alvo de vias de sinalização específicas que atuam nos mecanismos de metástases como exposto acima e que em conjunto reforçam a teoria sobre o sinergismo entres estes dois miRNAs no controle da MMP-9. 
6. Conclusão 
Demonstramos que a MMP-9 pode ser controlada, ainda que indiretamente; pelo miR-21 e miR-338-3p. O primeiro deles reduz a expressão de RECK ao mesmo tempo que eleva a de MMP-9, provocando maior invasão em um modelo in vitro. Já o segundo reduz a expressão de MMP-9 nas linhagens celulares e reduz a capacidade invasiva.

Identificamos ainda que a redução in vivo da expressão de MMP-9 em modelos de xenoenxerto de CaP pode ser realizada com a aplicação exógena do anti-miR-21 ou miR-338-3p, sendo este mais eficaz.

Com relação ao emprego da associação do miR-338-3p com anti-miR21 demonstramos que ela permite menor expressão de MMP-9 tanto in vitro como in vivo quando comparada ao uso isolado dos mesmos microRNAs. 
7. REFERÊNCIAS 
1. Howlader N, Noone A, Krapcho M, Garshell J, Miller D, Altekruse S, et al. SEER Cancer Statistics Review, 1975-2012. National Cancer Institute 2014.

2. Ilic D, Neuberger MM, Djulbegovic M, Dahm P. Screening for prostate cancer. Cochrane Database Syst Rev. 2013;1:Cd004720.

3. Faria EF, Carvalhal GF, Vieira RA, Silva TB, Mauad EC, Tobias-Machado M, et al. Comparison of clinical and pathologic findings of prostate cancers detected through screening versus conventional referral in Brazil. Clin Genitourin Cancer. 2011;9(2):104-8.

4. Klotz L, Vesprini D, Sethukavalan P, Jethava V, Zhang L, Jain S, et al. Long-term follow-up of a large active surveillance cohort of patients with prostate cancer. J Clin Oncol. 2015;33(3):272-7.

5. Mottet N, Bellmunt J, Briers E, Bolla M, Cornford P, De Santis M, et al. European Association of Urology Prostate Cancer Guidelines. 2015.

6. Liaw BC, Shevach J, Oh WK. Systemic therapy for the treatment of hormone-sensitive metastatic prostate cancer: from intermittent androgen deprivation therapy to chemotherapy. Curr Urol Rep. 2015;16(3):13.

7. Kirby M, Hirst C, Crawford ED. Characterising the castration-resistant prostate cancer population: a systematic review. Int J Clin Pract. 2011;65(11):1180-92.

8. Wadosky KM, Koochekpour S. Molecular mechanisms underlying resistance to androgen deprivation therapy in prostate cancer. Oncotarget. 2016;7(39):64447-70.

9. Nuhn P, De Bono JS, Fizazi K, Freedland SJ, Grilli M, Kantoff PW, et al. Update on Systemic Prostate Cancer Therapies: Management of Metastatic Castration-resistant Prostate Cancer in the Era of Precision Oncology. Eur Urol. 2018.

10. Kumar V, Abbas A, Fausto N. Pathologic basis of disease. $8^{\text {th }}$ ed. Philadelphia: Elsevier; 2010.

11. Hanahan D, Weinberg RA. Hallmarks of cancer: the next generation. Cell. 2011;144(5):646-74.

12. Sleeman JP. Metastasis: understanding is the beginning of order in chaos. Semin Cancer Biol. 2012;22(3):173.

13. Sleeman JP, Christofori G, Fodde R, Collard JG, Berx G, Decraene C, et al. Concepts of metastasis in flux: the stromal progression model. Semin Cancer Biol. 2012b;22(3):174-86.

14. Clarke NW, Hart CA, Brown MD. Molecular mechanisms of metastasis in prostate cancer. Asian J Androl. 2009;11(1):57-67.

15. Spano D, Heck C, De Antonellis P, Christofori G, Zollo M. Molecular networks that regulate cancer metastasis. Semin Cancer Biol. 2012;22(3):234-49.

16. Visse R, Nagase H. Matrix metalloproteinases and tissue inhibitors of metalloproteinases: structure, function, and biochemistry. Circ Res. 2003;92(8):827-39.

17. Nagase H, Woessner JF. Matrix metalloproteinases. J Biol Chem. 1999;274(31):21491-4.

18. Baker AH, Edwards DR, Murphy G. Metalloproteinase inhibitors: biological actions and therapeutic opportunities. J Cell Sci. 2002;115(Pt 19):3719-27.

19. Westermarck J, Kähäri VM. Regulation of matrix metalloproteinase expression in tumor invasion. FASEB J. 1999;13(8):781-92.

20. McCawley LJ, Matrisian LM. Matrix metalloproteinases: they're not just for matrix anymore! Curr Opin Cell Biol. 2001;13(5):534-40.

21. McCawley LJ, Matrisian LM. Tumor progression: defining the soil round the tumor seed. Curr Biol. 2001;11(1):R25-7.

22. Eissa S, Ali-Labib R, Swellam M, Bassiony M, Tash F, El-Zayat TM. Noninvasive diagnosis of bladder cancer by detection of matrix metalloproteinases (MMP-2 and MMP-9) and their inhibitor (TIMP-2) in urine. Eur Urol. 2007;52(5):1388-96.

23. Liabakk NB, Talbot I, Smith RA, Wilkinson K, Balkwill F. Matrix metalloprotease 2 (MMP-2) and matrix metalloprotease 9 (MMP-9) type IV collagenases in colorectal cancer. Cancer Res. 1996;56(1):190-6.

24. Itoh Y, Nagase H. Matrix metalloproteinases in cancer. Essays Biochem. 2002;38:21-36.

25. Jung K, Nowak L, Lein M, Priem F, Schnorr D, Loening SA. Matrix metalloproteinases 1 and 3 , tissue inhibitor of metalloproteinase-1 and the complex of metalloproteinase-1/tissue inhibitor in plasma of patients with prostate cancer. Int J Cancer. 1997;74(2):220-3.

26. Sang QA, Schwartz MA, Li H, Chung LW, Zhau HE. Targeting matrix metalloproteinases in human prostate cancer. Ann N Y Acad Sci. 1999;878:538-40.

27. Lein M, Nowak L, Jung K, Laube C, Ulbricht N, Schnorr D, et al. Metalloproteinases and tissue inhibitors of matrix-metalloproteinases in plasma of patients with prostate cancer and in prostate cancer tissue. Ann N Y Acad Sci. 1999;878:544-6.

28. Sauer CG, Kappeler A, Spath M, Kaden JJ, Michel MS, Mayer D, et al. Expression and activity 
of matrix metalloproteinases-2 and -9 in serum, core needle biopsies and tissue specimens of prostate cancer patients. Virchows Arch. 2004;444(6):518-26.

29. Morgia G, Falsaperla M, Malaponte G, Madonia M, Indelicato M, Travali S, et al. Matrix metalloproteinases as diagnostic (MMP-13) and prognostic (MMP-2, MMP-9) markers of prostate cancer. Urol Res. 2005;33(1):44-50.

30. Escaff S, Fernandez JM, Gonzalez LO, Suarez A, Gonzalez-Reyes S, Gonzalez JM, et al. Study of matrix metalloproteinases and their inhibitors in prostate cancer. Br J Cancer. 2010;102(5):922-9.

31. Boxler S, Djonov V, Kessler TM, Hlushchuk R, Bachmann LM, Held U, et al. Matrix metalloproteinases and angiogenic factors: predictors of survival after radical prostatectomy for clinically organ-confined prostate cancer? Am J Pathol. 2010;177(5):2216-24.

32. Brehmer B, Biesterfeld S, Jakse G. Expression of matrix metalloproteinases (MMP-2 and -9) and their inhibitors (TIMP-1 and -2) in prostate cancer tissue. Prostate Cancer Prostatic Dis. 2003;6(3):217-22.

33. Dos Reis ST, Pontes J, Villanova FE, Borra PM, Antunes AA, Dall'oglio MF, et al. Genetic polymorphisms of matrix metalloproteinases: susceptibility and prognostic implications for prostate cancer. J Urol. 2009;181(5):2320-5.

34. Reis ST, Pontes-Junior J, Antunes AA, de Sousa-Canavez JM, Dall'Oglio MF, Passerotti CC, et al. MMP-9 overexpression due to TIMP-1 and RECK underexpression is associated with prognosis in prostate cancer. Int J Biol Markers. 2011a;26(4):255-61.

35. Reis ST, Antunes AA, Pontes-Junior J, Sousa-Canavez JM, Dall'Oglio MF, Piantino CB, et al. Underexpression of MMP-2 and its regulators, TIMP2, MT1-MMP and IL-8, is associated with prostate cancer. Int Braz J Urol. 2012;38(2):167-74.

36. Wojtowicz-Praga S, Torri J, Johnson M, Steen V, Marshall J, Ness E, et al. Phase I trial of Marimastat, a novel matrix metalloproteinase inhibitor, administered orally to patients with advanced lung cancer. J Clin Oncol. 1998;16(6):2150-6.

37. Levitt NC, Eskens FA, O'Byrne KJ, Propper DJ, Denis LJ, Owen SJ, et al. Phase I and pharmacological study of the oral matrix metalloproteinase inhibitor, MMI270 (CGS27023A), in patients with advanced solid cancer. Clin Cancer Res. 2001;7(7):1912-22.

38. Rizvi NA, Humphrey JS, Ness EA, Johnson MD, Gupta E, Williams K, et al. A phase I study of oral BMS-275291, a novel nonhydroxamate sheddase-sparing matrix metalloproteinase inhibitor, in patients with advanced or metastatic cancer. Clin Cancer Res. 2004;10(6):1963-70.

39. Chiappori AA, Eckhardt SG, Bukowski R, Sullivan DM, Ikeda M, Yano Y, et al. A phase I pharmacokinetic and pharmacodynamic study of s-3304, a novel matrix metalloproteinase inhibitor, in patients with advanced and refractory solid tumors. Clin Cancer Res. 2007;13(7):2091-9.

40. Chu QS, Forouzesh B, Syed S, Mita M, Schwartz G, Cooper J, et al. A phase II and pharmacological study of the matrix metalloproteinase inhibitor (MMPI) COL-3 in patients with advanced soft tissue sarcomas. Invest New Drugs. 2007;25(4):359-67.

41. Hoelder S, Clarke PA, Workman P. Discovery of small molecule cancer drugs: successes, challenges and opportunities. Mol Oncol. 2012;6(2):155-76.

42. Wang Z, Rao DD, Senzer N, Nemunaitis J. RNA interference and cancer therapy. Pharm Res. 2011;28(12):2983-95.

43. Jana S, Chakraborty C, Nandi S, Deb JK. RNA interference: potential therapeutic targets. Appl Microbiol Biotechnol. 2004;65(6):649-57.

44. Lin S, Gregory RI. MicroRNA biogenesis pathways in cancer. Nat Rev Cancer. 2015;15(6):321-

33.

45. Chen CZ, Lodish HF. MicroRNAs as regulators of mammalian hematopoiesis. Semin Immunol. 2005; 17(2):155-65.

46. Huang Y, Zou Q, Song H, Song F, Wang L, Zhang G, et al. A study of miRNAs targets prediction and experimental validation. Protein Cell. 2010;1(11):979-86.

47. Witkos TM, Koscianska E, Krzyzosiak WJ. Practical Aspects of microRNA Target Prediction. Curr Mol Med. 2011;11(2):93-109.

48. Reis ST, Pontes-Junior J, Antunes AA, Dall'Oglio MF, Dip N, Passerotti CC, et al. miR-21 may acts as an oncomir by targeting RECK, a matrix metalloproteinase regulator, in prostate cancer. BMC Urol. 2012a;12:14.

49. Ivanovska I, Cleary MA. Combinatorial microRNAs: working together to make a difference. Cell Cycle. 2008;7(20):3137-42.

50. Huang XH, Chen JS, Wang Q, Chen XL, Wen L, Chen LZ, et al. miR-338-3p suppresses invasion of liver cancer cell by targeting smoothened. J Pathol. 2011;225(3):463-72.

51. Livak KJ, Schmittgen TD. Analysis of relative gene expression data using real-time quantitative 
PCR and the 2(-Delta Delta C(T)) Method. Methods. 2001;25(4):402-8.

52. Klerk CP, Overmeer RM, Niers TM, Versteeg HH, Richel DJ, Buckle T, et al. Validity of bioluminescence measurements for noninvasive in vivo imaging of tumor load in small animals. Biotechniques. 2007;43(1 Suppl):7-13, 30.

53. Sasahara RM, Takahashi C, Sogayar MC, Noda M. Oncogene-mediated downregulation of RECK, a novel transformation suppressor gene. Braz J Med Biol Res. 1999;32(7):891-5.

54. Takahashi C, Sheng Z, Horan TP, Kitayama H, Maki M, Hitomi K, et al. Regulation of matrix metalloproteinase-9 and inhibition of tumor invasion by the membrane-anchored glycoprotein RECK. Proc Natl Acad Sci U S A. 1998;95(22):13221-6.

55. Oh J, Takahashi R, Kondo S, Mizoguchi A, Adachi E, Sasahara RM, et al. The membraneanchored MMP inhibitor RECK is a key regulator of extracellular matrix integrity and angiogenesis. Cell. 2001;107(6):789-800.

56. Takeuchi T, Hisanaga M, Nagao M, Ikeda N, Fujii H, Koyama F, et al. The membrane-anchored matrix metalloproteinase (MMP) regulator RECK in combination with MMP-9 serves as an informative prognostic indicator for colorectal cancer. Clin Cancer Res. 2004;10(16):5572-9.

57. Li Y, Zhang Y, Zheng Q. Expression of RECK gene and MMP-9 in hilar cholangiocarcinoma and its clinical significance. J Huazhong Univ Sci Technolog Med Sci. 2005;25(5):552-4.

58. Correa TC, Brohem CA, Winnischofer SM, da Silva Cardeal LB, Sasahara RM, Taboga SR, et al. Downregulation of the RECK-tumor and metastasis suppressor gene in glioma invasiveness. J Cell Biochem. 2006;99(1):156-67.

59. Song SY, Son HJ, Nam E, Rhee JC, Park C. Expression of reversion-inducing-cysteine-rich protein with Kazal motifs (RECK) as a prognostic indicator in gastric cancer. Eur $\mathbf{J}$ Cancer. 2006;42(1):101-8.

60. Kang HG, Kim HS, Kim KJ, Oh JH, Lee MR, Seol SM, et al. RECK expression in osteosarcoma: correlation with matrix metalloproteinases activation and tumor invasiveness. J Orthop Res. 2007;25(5):696-702.

61. Chang CK, Hung WC, Chang HC. The Kazal motifs of RECK protein inhibit MMP-9 secretion and activity and reduce metastasis of lung cancer cells in vitro and in vivo. J Cell Mol Med. 2008;12(6B):2781-9.

62. Clark JC, Thomas DM, Choong PF, Dass CR. RECK--a newly discovered inhibitor of metastasis with prognostic significance in multiple forms of cancer. Cancer Metastasis Rev. 2007;26(3-4):675-83.

63. Ribas J, Lupold SE. The transcriptional regulation of miR-21, its multiple transcripts, and their implication in prostate cancer. Cell Cycle. 2010;9(5):923-9.

64. Zhang HL, Yang LF, Zhu Y, Yao XD, Zhang SL, Dai B, et al. Serum miRNA-21: elevated levels in patients with metastatic hormone-refractory prostate cancer and potential predictive factor for the efficacy of docetaxel-based chemotherapy. Prostate. 2011;71(3):326-31.

65. Simizu S, Takagi S, Tamura Y, Osada H. RECK-mediated suppression of tumor cell invasion is regulated by glycosylation in human tumor cell lines. Cancer Res. 2005;65(16):7455-61.

66. Hsu MC, Chang HC, Hung WC. HER-2/neu represses the metastasis suppressor RECK via ERK and Sp transcription factors to promote cell invasion. J Biol Chem. 2006;281(8):4718-25.

67. Berger R, Lin DI, Nieto M, Sicinska E, Garraway LA, Adams H, et al. Androgen-dependent regulation of Her-2/neu in prostate cancer cells. Cancer Res. 2006;66(11):5723-8.

68. Ricciardelli C, Jackson MW, Choong CS, Stahl J, Marshall VR, Horsfall DJ, et al. Elevated levels of HER-2/neu and androgen receptor in clinically localized prostate cancer identifies metastatic potential. Prostate. 2008;68(8):830-8.

69. Mercatelli N, Coppola V, Bonci D, Miele F, Costantini A, Guadagnoli M, et al. The inhibition of the highly expressed miR-221 and miR-222 impairs the growth of prostate carcinoma xenografts in mice. PLoS One. 2008;3(12):e4029.

70. Jazbutyte V, Thum T. MicroRNA-21: from cancer to cardiovascular disease. Curr Drug Targets. 2010;11(8):926-35.

71. Shi GH, Ye DW, Yao XD, Zhang SL, Dai B, Zhang HL, et al. Involvement of microRNA-21 in mediating chemo-resistance to docetaxel in androgen-independent prostate cancer PC3 cells. Acta Pharmacol Sin. 2010;31(7):867-73.

72. Shen KH, Liao AC, Hung JH, Lee WJ, Hu KC, Lin PT, et al. alpha-Solanine inhibits invasion of human prostate cancer cell by suppressing epithelial-mesenchymal transition and MMPs expression. Molecules. 2014;19(8):11896-914.

73. Shukla CJ, Edwards D, Sethia KK. Re: Anja Rabien, Mick Burkhardt, Monika Jung, Florian Fritzsche, Martin Ringsdorf, Hanka Schicktanz, Stefan A. Loening, Glen Kristiansen and Klaus Jung. Decreased RECK expression indicating proteolytic imbalance in prostate cancer is associated with higher 
tumor aggressiveness and risk of prostate-specific antigen relapse after radical prostatectomy. Eur Urol 2007;51:1259-66. Eur Urol. 52. Switzerland2007. p. 1533-4; author reply 4-5.

74. Gaedcke J, Grade M, Camps J, Sokilde R, Kaczkowski B, Schetter AJ, et al. The rectal cancer microRNAome--microRNA expression in rectal cancer and matched normal mucosa. Clin Cancer Res. 2012;18(18):4919-30.

75. Fu X, Tan D, Hou Z, Hu Z, Liu G, Ouyang Y, et al. The effect of miR-338-3p on HBx deletionmutant (HBx-d382) mediated liver-cell proliferation through CyclinD1 regulation. PLoS One. 2012;7(8):e43204.

76. Yang M, Liu R, Sheng J, Liao J, Wang Y, Pan E, et al. Differential expression profiles of microRNAs as potential biomarkers for the early diagnosis of esophageal squamous cell carcinoma. Oncol Rep. 2013;29(1):169-76.

77. Maclellan SA, Lawson J, Baik J, Guillaud M, Poh CF, Garnis C. Differential expression of miRNAs in the serum of patients with high-risk oral lesions. Cancer Med. 2012;1(2):268-74.

78. Li P, Chen X, Su L, Li C, Zhi Q, Yu B, et al. Epigenetic silencing of miR-338-3p contributes to tumorigenicity in gastric cancer by targeting SSX2IP. PLoS One. 2013;8(6):e66782.

79. Xue Q, Sun K, Deng HJ, Lei ST, Dong JQ, Li GX. MicroRNA-338-3p inhibits colorectal carcinoma cell invasion and migration by targeting smoothened. Jpn J Clin Oncol. 2014;44(1):13-21.

80. Sun J, Feng X, Gao S, Xiao Z. microRNA-338-3p functions as a tumor suppressor in human nonsmallcell lung carcinoma and targets Ras-related protein 14. Mol Med Rep. 2015;11(2):1400-6.

81. Zhang X, Wang C, Li H, Niu X, Liu X, Pei D, et al. miR-338-3p inhibits the invasion of renal cell carcinoma by downregulation of ALK5. Oncotarget. 2017;8(38):64106-13.

82. Li G, Chong T, Yang J, Li H, Chen H. Kinesin motor protein KIFC1 is a target protein of miR338-3p and associated with poor prognosis and progression of renal cell carcinoma. Oncol Res. 2018.

83. Sekino Y, Oue N, Shigematsu Y, Ishikawa A, Sakamoto N, Sentani K, et al. KIFC1 induces resistance to docetaxel and is associated with survival of patients with prostate cancer. Urol Oncol. 2017;35(1):31.e13-31.e20.

84. Sun K, Deng HJ, Lei ST, Dong JQ, Li GX. miRNA-338-3p suppresses cell growth of human colorectal carcinoma by targeting smoothened. World J Gastroenterol. 2013;19(14):2197-207.

85. Sandhiya S, Melvin G, Kumar SS, Dkhar SA. The dawn of hedgehog inhibitors: Vismodegib. J Pharmacol Pharmacother. 2013;4(1):4-7.

86. Sanchez P, Hernández AM, Stecca B, Kahler AJ, DeGueme AM, Barrett A, et al. Inhibition of prostate cancer proliferation by interference with SONIC HEDGEHOG-GLI1 signaling. Proc Natl Acad Sci U S A. 2004;101(34):12561-6.

87. Sheng T, Li C, Zhang X, Chi S, He N, Chen K, et al. Activation of the hedgehog pathway in advanced prostate cancer. Mol Cancer. 2004;3:29.

88. Karhadkar SS, Bova GS, Abdallah N, Dhara S, Gardner D, Maitra A, et al. Hedgehog signalling in prostate regeneration, neoplasia and metastasis. Nature. 2004;431(7009):707-12.

89. Datta S, Datta MW. Sonic Hedgehog signaling in advanced prostate cancer. Cell Mol Life Sci. 2006;63(4):435-48.

90. Wang K, Pan L, Che X, Cui D, Li C. Sonic Hedgehog/GLI signaling pathway inhibition restricts cell migration and invasion in human gliomas. Neurol Res. 2010;32(9):975-80.

91. Das S, Samant RS, Shevde LA. Hedgehog signaling induced by breast cancer cells promotes osteoclastogenesis and osteolysis. J Biol Chem. 2011;286(11):9612-22.

92. Onishi H, Kai M, Odate S, Iwasaki H, Morifuji Y, Ogino T, et al. Hypoxia activates the hedgehog signaling pathway in a ligand-independent manner by upregulation of Smo transcription in pancreatic cancer. Cancer Sci. 2011;102(6):1144-50.

93. Zhang P, Shao G, Lin X, Liu Y, Yang Z. MiR-338-3p inhibits the growth and invasion of nonsmall cell lung cancer cells by targeting IRS2. Am J Cancer Res. 2017;7(1):53-63.

94. Huang SP, Bao BY, Hour TC, Huang CY, Yu CC, Liu CC, et al. Genetic variants in CASP3, BMP5, and IRS2 genes may influence survival in prostate cancer patients receiving androgen-deprivation therapy. PLoS One. 2012;7(7):e41219.

95. Chen X, Pan M, Han L, Lu H, Hao X, Dong Q. miR-338-3p suppresses neuroblastoma proliferation, invasion and migration through targeting PREX2a. FEBS Lett. 2013;587(22):3729-37.

96. Zhang Y, Shi B, Chen J, Hu L, Zhao C. MiR-338-3p targets pyruvate kinase M2 and affects cell proliferation and metabolism of ovarian cancer. Am J Transl Res. 2016;8(7):3266-73.

97. Wong N, Yan J, Ojo D, De Melo J, Cutz JC, Tang D. Changes in PKM2 associate with prostate cancer progression. Cancer Invest. 2014;32(7):330-8.

98. Chen JT, Yao KH, Hua L, Zhang LP, Wang CY, Zhang JJ. MiR-338-3p inhibits the proliferation and migration of gastric cancer cells by targeting ADAM17. Int J Clin Exp Pathol. 2015;8(9):10922-8. 
99. Xiao LJ, Lin P, Lin F, Liu X, Qin W, Zou HF, et al. ADAM17 targets MMP-2 and MMP-9 via EGFR-MEK-ERK pathway activation to promote prostate cancer cell invasion. Int J Oncol. 2012;40(5):1714-24.

100. Lv L, Yuan J, Huang T, Zhang C, Zhu Z, Wang L, et al. Stabilization of Snail by HIF-1 $\alpha$ and TNF- $\alpha$ is required for hypoxia-induced invasion in prostate cancer PC3 cells. Mol Biol Rep. 2014;41(7):4573-82.

101. Bakkar A, Alshalalfa M, Petersen LF, Abou-Ouf H, Al-Mami A, Hegazy SA, et al. microRNA 338-3p exhibits tumor suppressor role and its down-regulation is associated with adverse clinical outcome in prostate cancer patients. Mol Biol Rep. 2016;43(4):229-40.

102. Xu J, Li CX, Li YS, Lv JY, Ma Y, Shao TT, et al. MiRNA-miRNA synergistic network: construction via co-regulating functional modules and disease miRNA topological features. Nucleic Acids Res. 2011;39(3):825-36.

103. Li X, Zhen Z, Tang G, Zheng C, Yang G. MiR-29a and MiR-140 Protect Chondrocytes against the Anti-Proliferation and Cell Matrix Signaling Changes by IL-1 $\beta$. Mol Cells. 2016;39(2):103-10.

104. Guo Y, An R, Zhao R, Sun Y, Liu M, Tian L. miR-375 exhibits a more effective tumorsuppressor function in laryngeal squamous carcinoma cells by regulating KLF4 expression compared with simple co-transfection of miR-375 and miR-206. Oncol Rep. 2016;36(2):952-60.

105. Chen B, Duan L, Yin G, Tan J, Jiang X. Simultaneously expressed miR-424 and miR-381 synergistically suppress the proliferation and survival of renal cancer cells---Cdc2 activity is up-regulated by targeting WEE1. Clinics (Sao Paulo). 2013;68(6):825-33.

106. Minakuchi Y, Takeshita F, Kosaka N, Sasaki H, Yamamoto Y, Kouno M, et al. Atelocollagenmediated synthetic small interfering RNA delivery for effective gene silencing in vitro and in vivo. Nucleic Acids Res. 2004;32(13):e109.

107. Park JK, Lee EJ, Esau C, Schmittgen TD. Antisense inhibition of microRNA-21 or -221 arrests cell cycle, induces apoptosis, and sensitizes the effects of gemcitabine in pancreatic adenocarcinoma. Pancreas. 2009;38(7):e190-9.

108. Dong CG, Wu WK, Feng SY, Wang XJ, Shao JF, Qiao J. Co-inhibition of microRNA-10b and microRNA-21 exerts synergistic inhibition on the proliferation and invasion of human glioma cells. Int J Oncol. 2012;41(3):1005-12. 
8. APÊNDICE 


\section{ARTIGOS CIENTÍFICOS PUBLICADOS}

1. Cancer Cell international

MIR-29B ENHANCES PROSTATE CANCER CELL INVASION INDEPENDENTLY OF MMP-2 EXPRESSION

\section{ARTIGOS CIENTÍFICOS SUBMETIDOS}

2. BMC CANCER

MIR-618: POSSIBLE CONTROL OVER TIMP-1 AND ITS EXPRESSION IN Localized Prostate Cancer

\section{CANCER LETTERS}

MIR-21 INHIBITOR AND MIR-338-3P SYNERGISTICALLY MODULATE MMP-9 IN Prostate Cancer

\section{CONGRESSOS}

1. XXXV CONGRESSO BRASILEIRO DE UROLOGIA

2. International Conference on Prostate Cancer 


\title{
miR-29b enhances prostate cancer cell invasion independently of MMP-2 expression
}

Renato F. Ivanavic "'O, Nayara I. Viana', Denis R. Morais', Iran A. Siva', Katia R. Leite', José Pantes-Jurior", Gustavo Inoue', Willam C Nahas', Mguel Sroug' and Sabrina T. Heis'

\begin{abstract}
Background. The ability to motastasise is cne of the most important characteritics of nooplastic cols. An imbelance betwoon the action of some matrix motalloprotolnases (MMPs) and tissue inhibitors of MevPs drives the irvasion procons. Some studies have suggosted that MMP-2 is invalved in motastasiz, while other studles have reportad that cal-

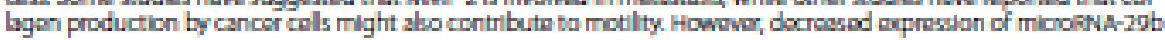

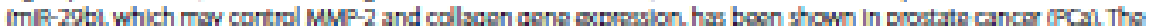
cbjocthes of the present study were to clarify whether MMP-2 as wall as collagons I and il fencodod by COC.1A1 and

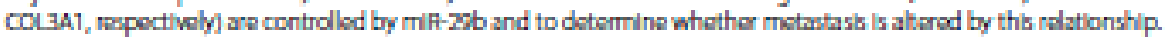
Methods: PCa DU145 and PC-3 colls ware transfocted wth $100 \mu \mathrm{L}$ of CPTI-MEM I containing 100 nmol of mle-29b

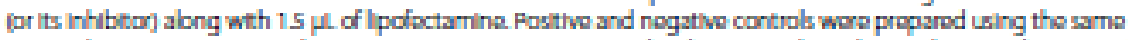
protocol MMP-2, COU1A1 and COL3A1 messenger FNA (mPNA) levels wore evaluatod va rod time polymerase chain

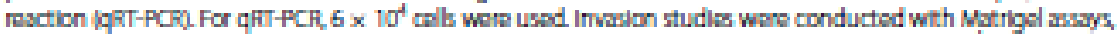
which simulate imvesion of the extracellular matrte by neaplastic colk. After tranefoctian of $3 \times 10^{4}$ colk, imesion was allowod to proceod for $48 \mathrm{~h}$. Imesive cols wore countad under an optical microscope. Each exporiment was porfarmod in triplicate

Rosults: MMP-2 mFNA was not aprassod in DU145 cols aftar transfoction with mif-29b. Aftor transfoction of cols with the min-29b inhibitor, COL1A1 $(p=0.02)$ and COL3A1 $(p=0.06)$ mPANA exprossion was incrossed in DU145 cols. and a lange number of transfocted DU145 and PC colls invadad the Matrigal merrbrane.

Conclusions: in vitro studies shawod that roducing the arnount of mil-20b may lad to higher PCa col invasian vis a process that is independent of MMP-Z. Colsgen expression, controlbd by mif-296, may faciltate this motility process. Thus, the prosert study suggerts that collagon production plays an active rolo in motastasis control and restoration of mif-2sb levels may dociase motastasis. Altogothet these findings support further oxplaration of drug therapy targoting this aspoct of the mokastars dirult.
\end{abstract}

Keywords: Prostate cancre, Matrib metalopecteinsses, Collagon, microfiNA

\section{Background}

Extrioellalar matrix (ECM) daruption by matrix metalloprotetnases (MMPs) is one of the key events in metastasts. MMPs ere regulated not only by ther natural inhibitors, tosue inhibitors of MMPs (TLMPs), but also at

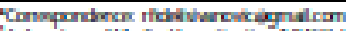

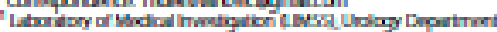

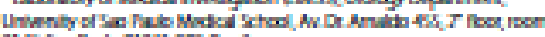

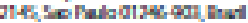

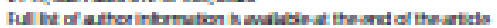

the post-transeriptional level by microlaNAs (manNAs). One of these MMPs is MMP-2, which msy be involved in prostate canor (PCa) progression and mctastasts [1, 2]-

However, there is evidence thet interstitial collagen may be involved in metastase, indicating an active role for the desmoplastic reaction observed in several canorr. Incresesd production of several types of colla. gens has been reported: type II and IV collogens were observed in coteosareoma [3], collagen type V was producod at elevated levels by fibrosaromens odls comparod 


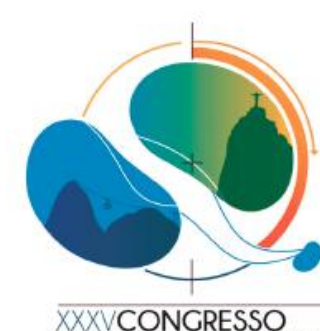

XXXVCONGRESSO

$\frac{\text { BRASILEIROUROLOCIA }}{31 / \text { OUT A } 4 / \text { NOV DE } 2015}$

Certificamos que o trabalho

BLOQUEIO DO MICRORNA-29B AUMENTA A INVASÃO DE CÉLULAS DE CÂNCER DE PRÓSTATA INDEPENDENTEMENTE DA

\section{METALOPROTEINASE 2}

dos autores: RENATO FIDELIS IVANOVIC; GUSTAVO INOUE; NAIARA VIANA; KÁTIA RAMOS MOREIRA LEITE; MIGUEL SROUGI; SABRINA THALITA REIS FARIA, foi apresentado, na modalidade Pódium (oral), no evento XXXV Congresso Brasileiro de Urologia ocorrido de 31 de outubro a 04 de novembro de 2015 no SulAmérica Centro de Convenções em Rio de Janeiro/RJ.

Rio de Janeiro, 04 de novembro de 2015
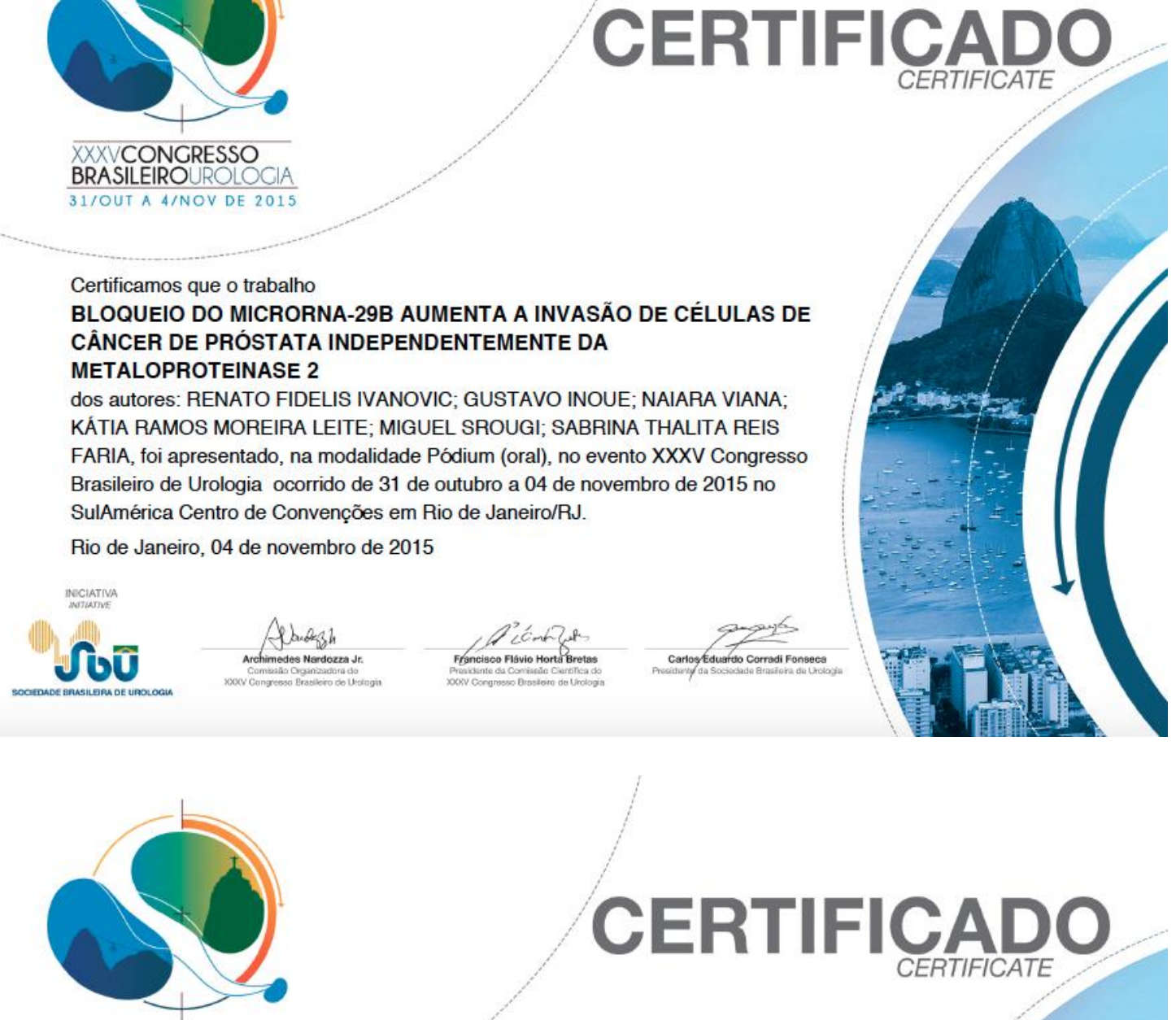

XXXVCONGRESSO

BRASILEIROUROLOCIA

31/OUT A 4/NOV DE 2015

Certificamos que o trabalho

MICRORNA CONTROL OF TIMP-1 AND TIMP-2 IN PROSTATE CANCER

dos autores: RENATO FIDELIS IVANOVIC; KATIA RAMOS MOREIRA LEITE;

WILLIAN CARLOS NAHAS; DENIS REIS; MIGUEL SROUGI; SABRINA THALITA

REIS, foi apresentado, na modalidade Pódium (oral), no evento XXXV Congresso

Brasileiro de Urologia ocorrido de 31 de outubro a 04 de novembro de 2015 no

SulAmérica Centro de Convenções em Rio de Janeiro/RJ.

Rio de Janeiro, 04 de novembro de 2015
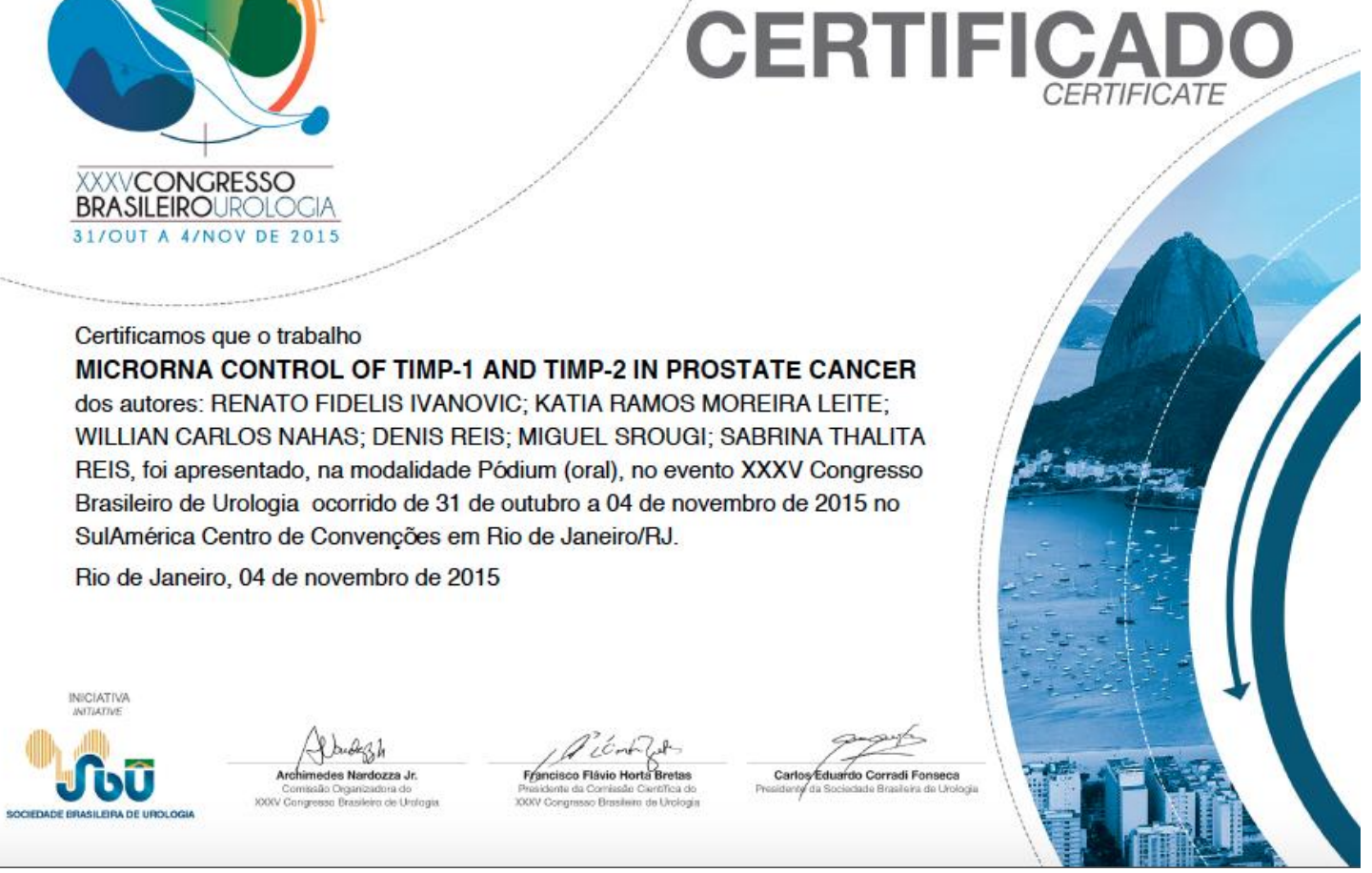
OMIGS:

nternational

Renatolvanovic et al., J Cancer Sci Ther 2015, 7:5 http://dx.doi.org/10.4172/1948-5956.S1.044

conferenceseries.com

International Conference on

Prostate Gancer

June 22-24, 2015 Florida, USA

Antagonism between miR-21 and 338-3p in prostate cancer invasion through regulation of matrix metalloproteinase 9

Renato Ivanovic, Denis Reis, Nayara Viana, Katia Leite, Alexandre Iscaife, Alberto Antunes, Jose Pontes Jr, William Nahas, Miguel Srougi and Sabrina Reis Săo Paulo University, Brazil

Introduction \& Objectives: Matrix metallo-proteinases (MMPs) are important in physiopathology of many tumors. MicroRNAs are new agents that control many processes and studies report MMPs regulation through them. MiRNA-21 and 338-3p may play a role in MMP-9 control. We evaluated prostate cancer cell invasion in vitro through the regulation of MMP-9 with these miRNAs.

Methods: LNCap, DU 145 and PC3 cells were transfected with miR-338-3p, miR-21 or their antagonists. A co-transfection (miR$21+$ antagomiR-338-3p and antagomiR-21+miR-338-3p) in DU145 was done. The MMP-9 mRNA expression was evaluated by qRTPCR relative quantification (2- $\Delta \Delta \mathrm{ct}$ ). Matrigel assays were done 48 hours after transfection with $3 \times 105$ cells. Those which have invaded were counted under optical microscope.

Results: We previously reported that miR-21 regulates MMP-9 through RECK protein in DU145. In the present study, miR-21 in PC3 cells reduced RECK expression ( $p=0.00$ ), increased MMP-9 mRNA ( $p=0.003$ ), MMP9 protein (ELISA detected, $p=0.60$ ) and Matrigel invasion ( $p=0.01$ ). Also in PC3, miR-338-3p decreased MMP-9 mRNA ( $p=0.04)$, MMP-9 protein ( $p=0.06$ ) and invasion in DU145 $(p=0.002)$, LNCap $(p=0.007)$ and PC3 (0.058). Transfecting two different miRNAs at the same time is a feasible method but only the transfection of anti-miR-21 together with miR-338-3p could significantly reduce the expression of MMP 9 mRNA. ( $p=0.05$ ). With this combination, less cells invaded the Matrigel chamber (mean $304 \times 114,87$ cells, $\mathrm{p}=0.13$ ).

Conclusions: MiR-21 and miR-338-3p regulate MMP-9 in opposite ways affecting cell invasion ability. The co-transfection of miR-21 antagonist+miR-338-3p reduces the MMP-9 expression.

\section{Biography}

Renato Ivanovic has completed Residency Program in Urology in São Paulo University. Currently he is a pursuing his Post graduation at the same institution. 